\begin{abstract}
UNIVERSIDADE DE SÃO PAULO - USP
FACULDADE DE FILOSOFIA, LETRAS E CIÊNCIAS HUMANAS DEPARTAMENTO DE LETRAS CLÁSSICAS E VERNÁCULAS PROGRAMA DE FILOLOGIA E LÍNGUA PORTUGUESA
\end{abstract}

MAYARA SUELLEN DE SOUSA

Marcas da oralidade nas manchetes do jornal popular Meia Hora de Notícias

Versão corrigida

São Paulo 


$$
\text { UNIVERSIDADE DE SÃO PAULO - USP }
$$

FACULDADE DE FILOSOFIA, LETRAS E CIÊNCIAS HUMANAS

DEPARTAMENTO DE LETRAS CLÁSSICAS E VERNÁCULAS

PROGRAMA DE FILOLOGIA E LÍNGUA PORTUGUESA

\title{
Marcas da oralidade nas manchetes do jornal popular Meia Hora de Notícias
}

Mayara Suellen de Sousa

\begin{abstract}
Dissertação de mestrado apresentada ao Programa de Pós-graduação em Filologia e Língua Portuguesa do Departamento de Letras Clássicas e Vernáculas da Faculdade de Filosofia, Letras e Ciências Humanas da Universidade de São Paulo, para a obtenção do título de Mestre em Letras.
\end{abstract}

Orientador: Prof. Dr. Hudinilson Urbano.

De acordo, 
Autorizo a reprodução e divulgação total ou parcial deste trabalho, por qualquer meio convencional ou eletrônico, para fins de estudo e pesquisa, desde que citada a fonte.

\author{
Catalogação da Publicação \\ Serviço de Biblioteca e Documentação
}

Faculdade de Filosofia, Letras e Ciências Humanas da Universidade de São Paulo

Sousa, Mayara Suellen.

Marcas da oralidade nas manchetes do jornal popular Meia Hora de Notícias / Mayara Suellen de Sousa ; orientador Hudinilson Urbano. - São Paulo, 2015.

$142 \mathrm{f}$ : : il.

Dissertação (Mestrado) - Faculdade de Filosofia, Letras e Ciências Humanas da Universidade de São Paulo. Departamento de Letras Clássicas e

Vernáculas. Área de concentração: Filologia e Língua Portuguesa

1. Jornalismo popular. 2. Oralidade. 3. Escrita. I. Urbano, Hudinilson. II. Título. III. Título: Marcas da oralidade nas manchetes do jornal popular Meia Hora de Notícias. 
SOUSA, Mayara Suellen. Marcas da oralidade nas manchetes do jornal popular Meia Hora de Notícias. São Paulo: Universidade de São Paulo, 2015. Dissertação (mestrado). Faculdade de Filosofia, Letras e Ciências Humanas. Universidade de São Paulo, São Paulo, 2015.

Dissertação de Mestrado apresentada ao Programa de Pós-Graduação em Filologia e Língua Portuguesa do Departamento de Letras Clássicas e Vernáculas da Faculdade de Filosofia, Letras e Ciências Humanas da Universidade de São Paulo, para obtenção do título de Mestre em Letras

BANCA EXAMINADORA

PROF. DR. HUDINILSON URBANO

(FFLCH-USP - PRESIDENTE)

PROFa. DR . ANA ROSA FERREIRA DIAS

(FFLCH-USP)

PROFa. DRạ. DENISE DURANTE

(UNIP) 
À minha mãe,

Ao Prof. Dr. Hudinilson Urbano, Ao meu noivo, Welden de Oliveira Miguel. 
Agradeço ao meu orientador, Professor Doutor Hudinilson Urbano, pela forma afetuosa com que conduziu esse processo de estudos, pela indicação das leituras, pela leitura cuidadosa e crítica do texto e por ser um mestre tão generoso e paciente.

Agradeço à professora Ana Rosa Ferreira Dias, não somente pela participação em minha qualificação, que em tanto contribuiu para este trabalho, como também pelos seus estudos, que muito me ajudaram e inspiraram para este trabalho.

Agradeço à professora Denise Durante, por sua minuciosa e dedicada participação na qualificação desta dissertação. Suas anotações e dicas foram essenciais.

Agradeço aos professores pelas quais as disciplinas tive a honra de passar em toda a jornada da execução deste trabalho.

A minha mãe, suporte e incentivo desde o começo.

Agradeço ao meu noivo, pelo suporte e paciência em entender todos os meus momentos de ausência e de distanciamento durante o mestrado, compreendendo quão importante este trabalho é para mim.

Agradeço aos amigos, por tantas vezes compreenderem que era necessário que faltasse aos nossos encontros, mas mesmo assim não se esquecessem de mim.

A Fabiane, colega e orientanda mais chique, por todo suporte, auxílio e palavras que me ajudaram a seguir até o final!

Às minhas amigas. Bruna e Amanda, cursamos a faculdade de Letras juntas, fomos para o mestrado também juntas, muito obrigada pela amizade e companhia. Obrigada, Pâmela, pelas caronas salvadoras e pela companhia deliciosa! Obrigada, Bruna, pela revisão deste trabalho. Obrigada, Patrícia, pelas orações que iluminaram meu caminho até o fim! 
Aos meus coordenadores e diretores nas escolas por onde passei durante o mestrado pela compreensão e liberação para minha participação em aulas, congressos e reuniões.

Aos meus alunos, por entenderem minhas variações de humor durante os momentos mais difíceis na conclusão desta dissertação.

Agradeço a Deus pela inspiração, força e luz nos momentos quando desistir parecia a única solução. 
Pois o silêncio não tem fisionomia, mas as palavras muitas faces.

Machado de Assis 


\section{RESUMO}

SOUSA, M. S. Marcas da oralidade nas manchetes do jornal popular Meia Hora de Notícias. 2014. 125 f. Dissertação (Mestrado) - Faculdade de Filosofia, Letras e Ciências Humanas. Universidade de São Paulo, São Paulo, 2014.

Este trabalho tem por finalidade apresentar resultados de pesquisa sobre as marcas da oralidade em textos escritos, especificamente em jornais considerados "populares" e nesta dissertação em manchetes do jornal Meia Hora de Notícias. Os jornais populares têm interesse maior pela divulgação da notícia e aproximação com o público leitor. A importância deste trabalho se dá pelo dinamismo da língua e a intensa troca entre o oral e o escrito. Essa troca faz da linguagem jornalística uma mistura entre o formal e o informal como maneira de envolver o maior número possível de leitores. Assim, recorrese a teóricos que apresentam conceitos referentes a questões de língua, linguagem, discurso e oralidade: Marcuschi (1993, 1995, 2004 e 2007), Koch e Oesterreicher $(1985,2007)$, Charaudeau $(2007,2008)$, Koch $(1997,2008)$, Ong (1998), Preti (1983, 2004), Dias (1996), Urbano (1998, 2000, 2006 e 2011), Fávero (2009). Nossos objetivos específicos são: delinear as particularidades da linguagem do jornalismo popular, verificar a relação entre língua falada e língua escrita, analisar as marcas de oralidade presentes no jornal Meia Hora de Notícias com base nos níveis discursivo e linguístico e compreender tais marcas de oralidade como estratégias de aproximação do leitor. Nossa hipótese é que a simulação de oralidade é uma estratégia do jornalismo popular, por isso a presença de ocorrências de oralidade nas manchetes. Pesquisamos 365 capas do jornal e optamos por uma análise mais detalhada de 30 manchetes. Enfocamos o campo discursivo, que contempla a narrativa, a língua culta $x$ a língua popular, as fórmulas fixas, as frases triádicas e 0 envolvimento do narrador nas notícias do jornal. No campo linguístico, destacamos os aspectos fonético, lexical e morfológico a fim de entender como se configuram os recursos de oralidade utilizados pelo Meia Hora de Notícias.

Palavras-Chave: Jornalismo popular; Oralidade; Escrita. 


\begin{abstract}
SOUSA, M. S. Marks of orality in the headlines of the popular newspaper Meia Hora de Notícias. 2014. 125 f. Dissertação (Mestrado) - Faculdade de Filosofia, Letras e Ciências Humanas. Universidade de São Paulo, São Paulo, 2014.
\end{abstract}

This paper aims to present research results about the marks of orality in written texts, specifically in newspapers considered "popular" and in this dissertation in newspaper headlines Meia Hora de Notícias. The tabloids have greater interest in the dissemination of news and approach to the reading public. The importance of this work is given by the dynamism of language and the intense exchange between the oral and the written, this change makes the journalistic language a mix between formal and informal as a way to involve the largest possible number of readers. Thus, we make use of theoretical concepts that have related to language issues, language, speech and orality: Marcuschi (1993, 1995, 2004 and 2007), Koch and Oesterreicher (1985, 2007), Charaudeau $(2007,2008)$, Koch $(1997,2008)$, Ong (1998), Preti $(1983,2004)$, Dias (1996), Urbano (1998, 2000, 2006 and 2011), Favero (2009). Our specific objectives are: to outline the particularities of the popular journalism language, verify the relationship between spoken and written language, analyze the marks of orality present in the newspaper Meia Hora de Notícias based on the discursive and linguistic levels and understand such brands as orality approximation strategies the reader. Our hypothesis is that orality simulation is a popular journalism strategy, so the presence of orality of occurrences in the headlines. We analyzed 365 newspaper covers and opted for a more detailed analysis of 30 headlines. We focus on the discursive field, which includes the narrative, the cultured language $x$ popular language, fixed formulas, the triadic phrases and the involvement of the narrator in the journal news. In the linguistic field, highlight the phonetic, lexical and morphological aspects in order to understand how to configure the orality of resources used by Meia Hora de Notícias.

Keywords: popular journalism; orality; writing. 


\section{SUMÁRIO}

INTRODUÇÃO

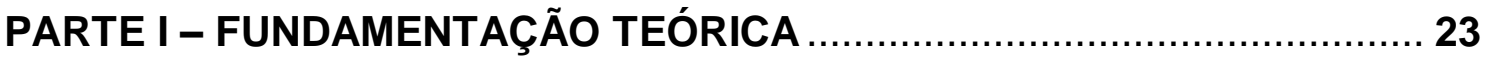

CAPÍTULO 1 - DA FALA PARA A ESCRITA - DISCURSO E ORALIDADE. 23

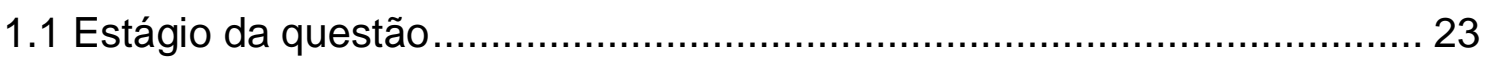

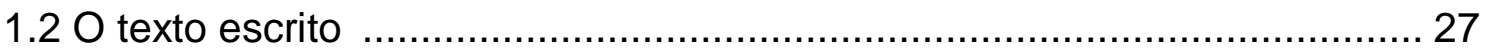

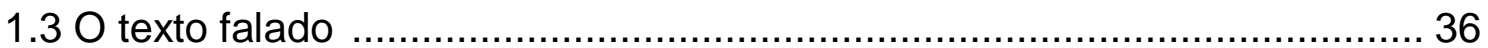

$1.4 \mathrm{O}$ texto híbrido - continuum ............................................................... 41

CAPÍTULO 2 - JORNALISMO - CONTEXTUALIZAÇÃO …......................... 45

2.1 Jornalismo: um percurso histórico ……………................................... 45

2.2 A imprensa no Brasil ......................................................................... 48

2.3 Jornalismo de "referência" ..................................................................... 51

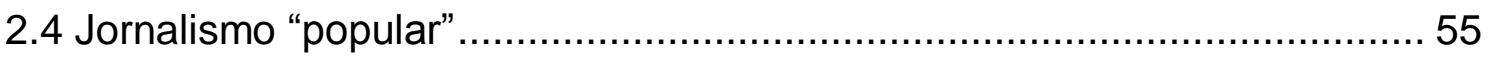

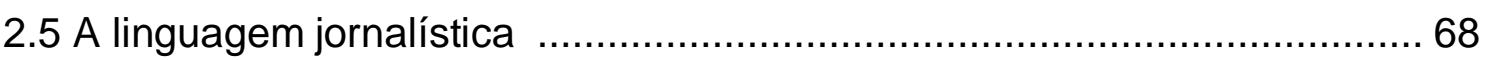

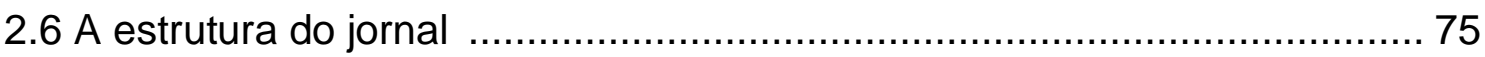

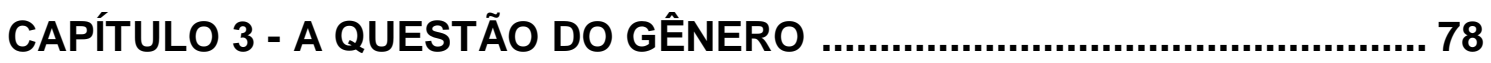

3.1 Gêneros primários e secundários...................................................... 78

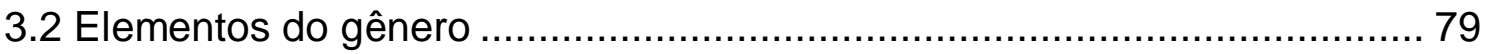

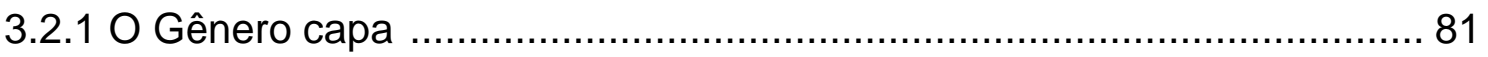

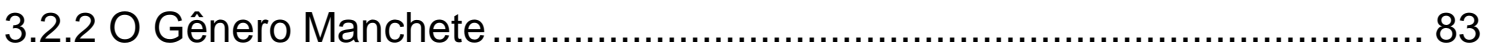

CAPÍTULO 4 - O CORPUS DA PESQUISA: JORNAL MEIA HORA DE

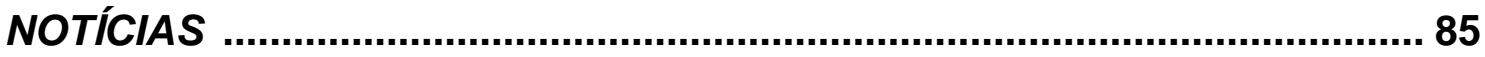

4.1 Contextualizando o jornal Meia Hora de Notícias........................................ 85 


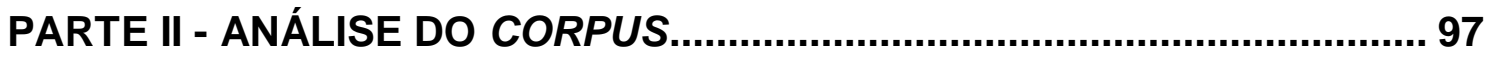

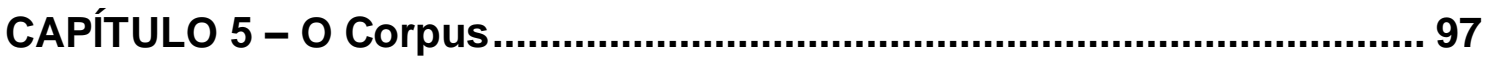

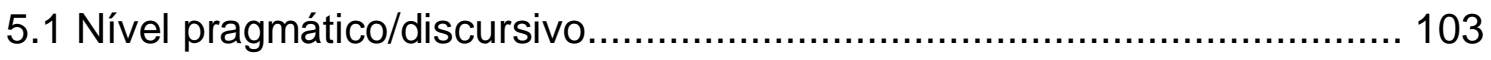

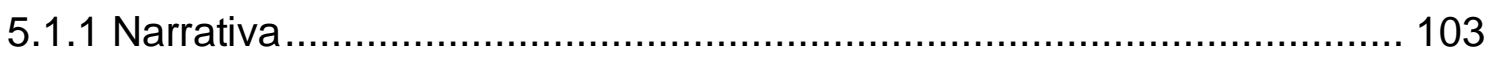

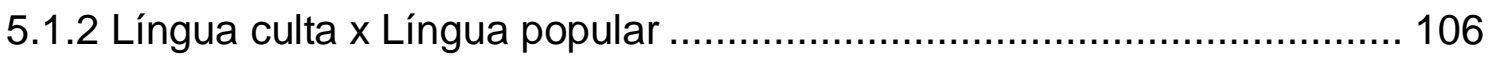

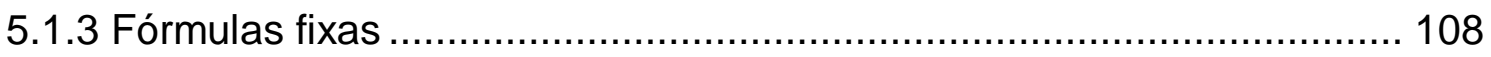

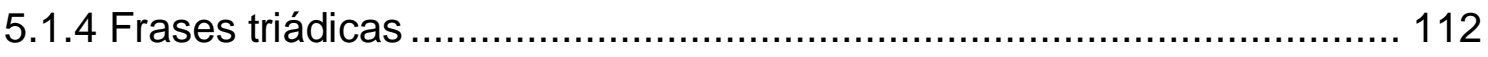

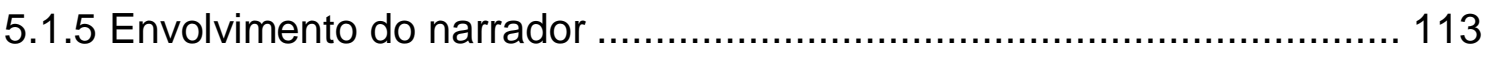

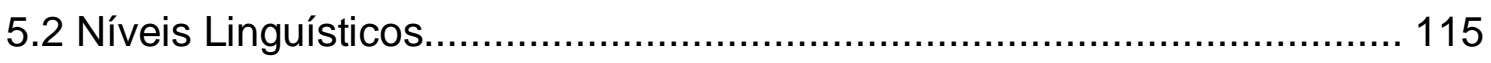

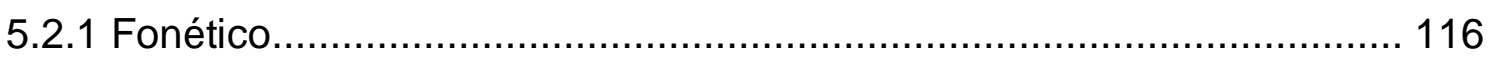

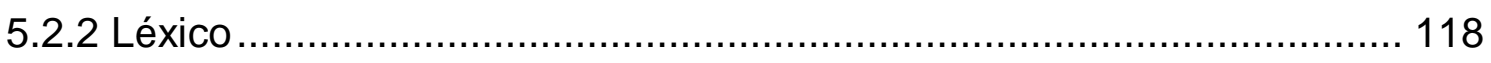

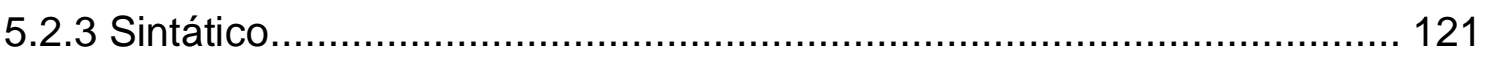

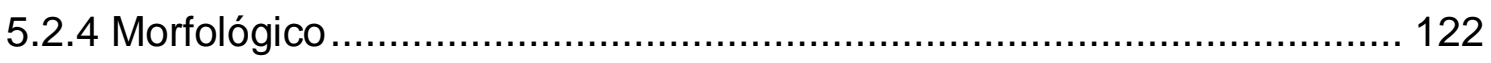

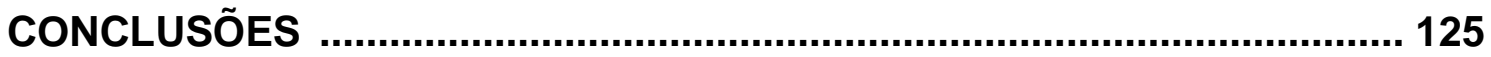

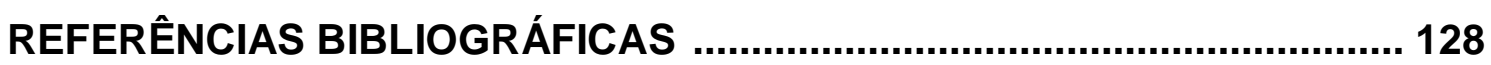

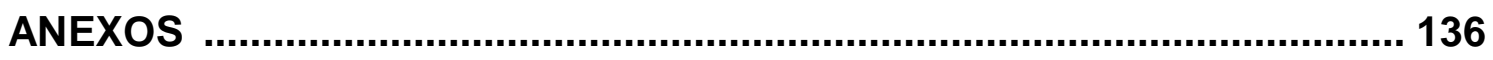




\section{LISTA DE QUADROS}

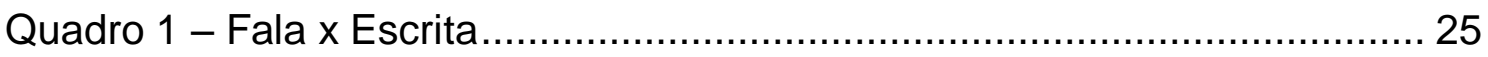

Quadro 2 - Imediatez comunicativa / oralidade .......................................... 26

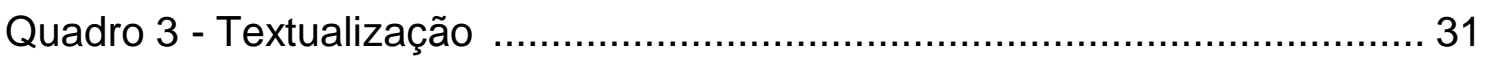




\section{LISTA DE TABELAS}

Tabela 1 - Jornal Meia Hora de Notícias .................................................... 91

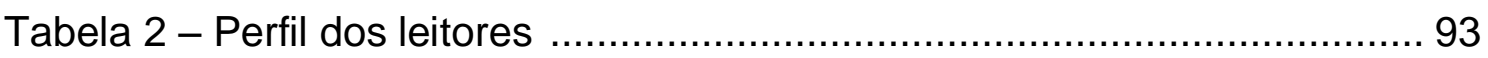

Tabela 3 - Classificação econômica dos consumidores brasileiros ................. 94

Tabela 4 - Indicação da temática das manchetes do jornal Meia Hora de

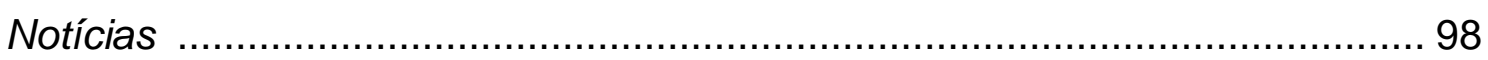




\section{LISTA DE ILUSTRAÇÕES}

Ilustração 1 - Folha de S. Paulo(14/09/2014) ............................................. 35

llustração 2 - Meia Hora de Notícias (14/09/2014) ....................................... 35

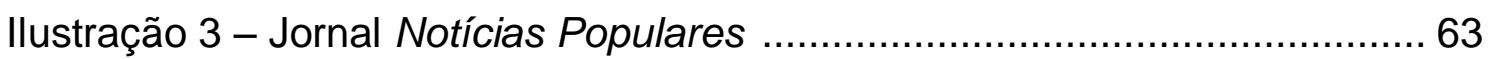

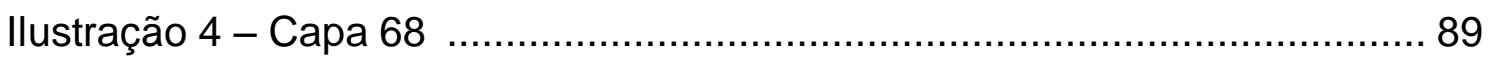

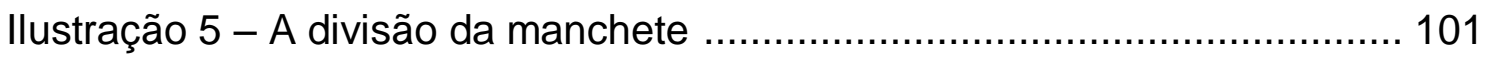

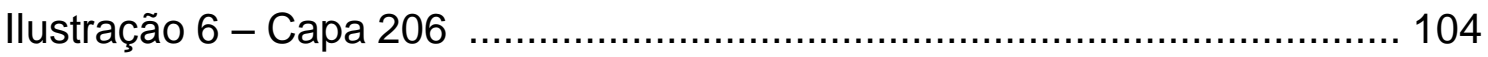

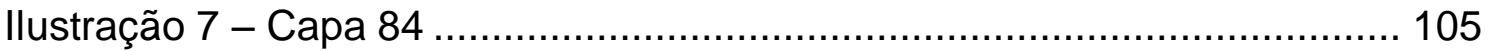

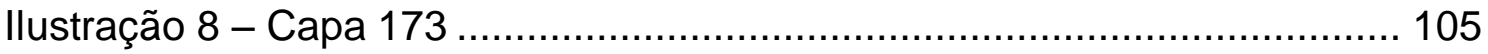

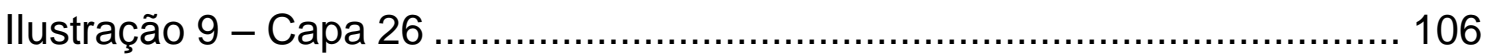

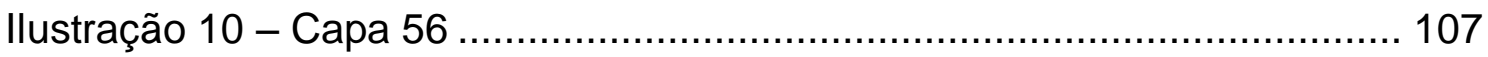

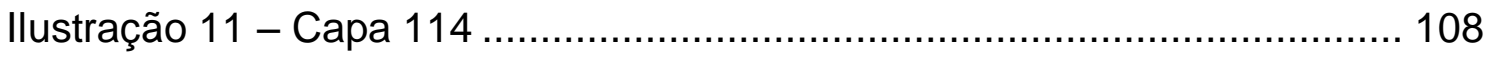

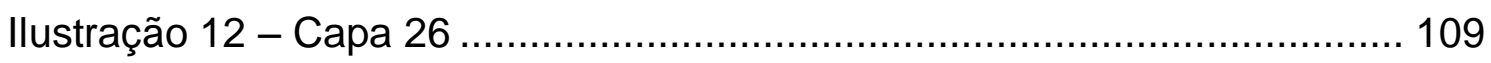

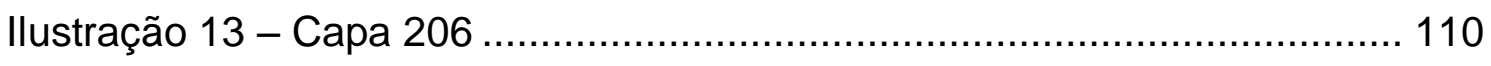

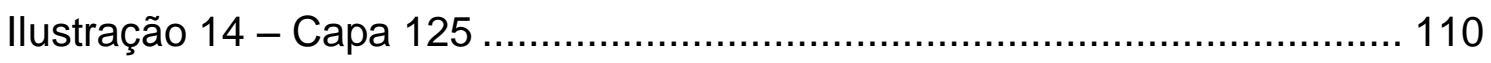

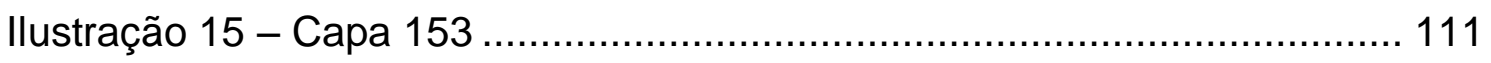

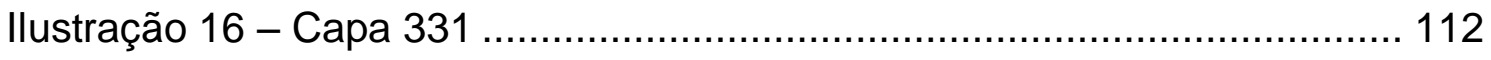

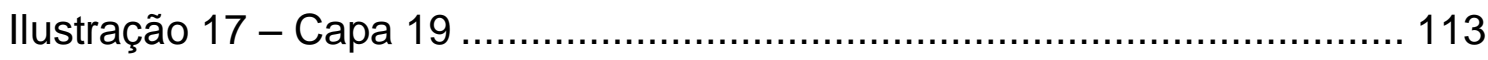

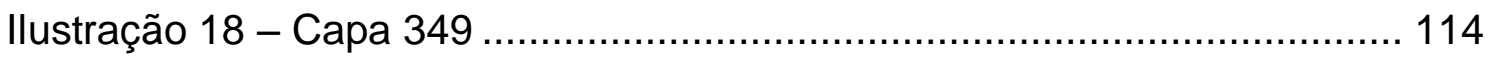

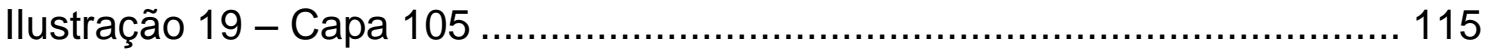

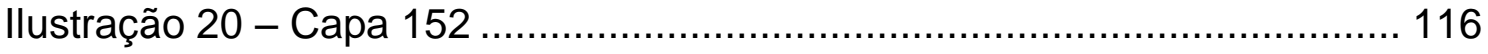

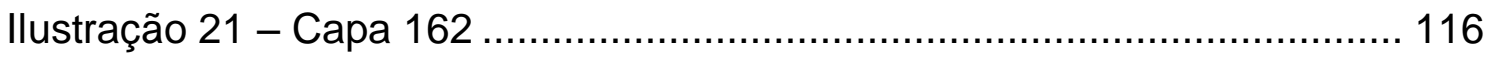

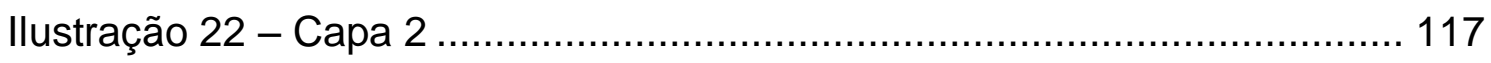

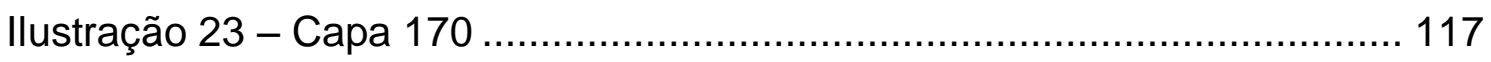

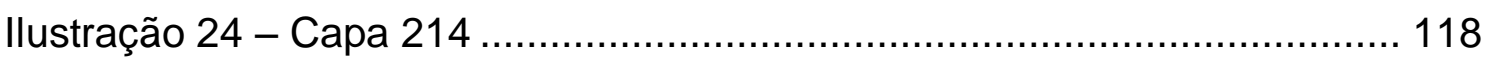

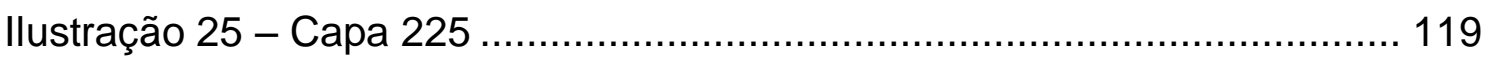




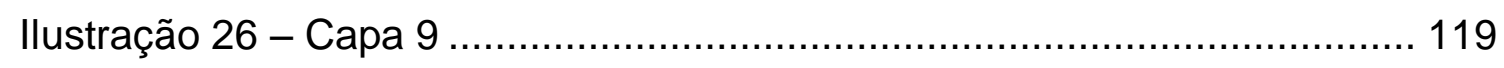

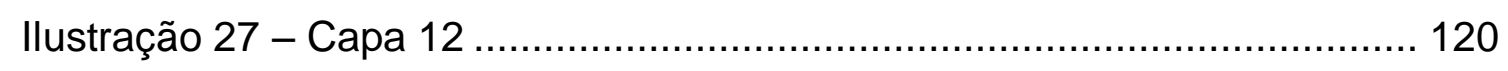

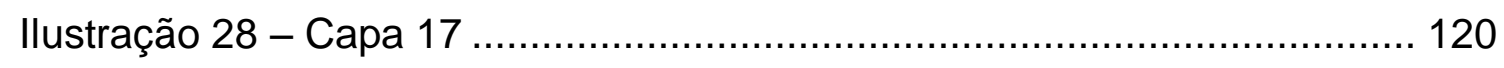

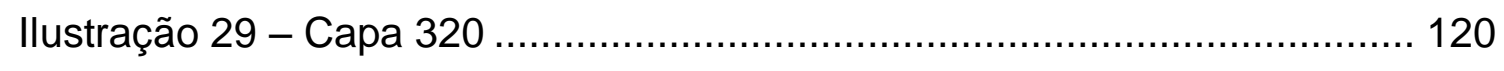

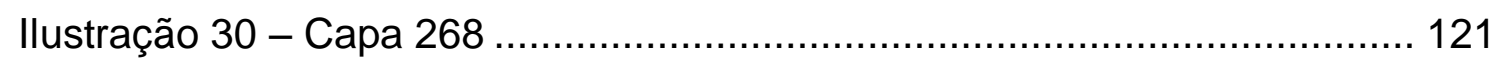

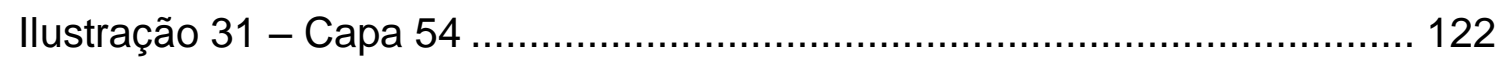

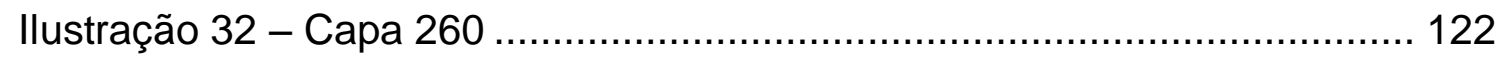

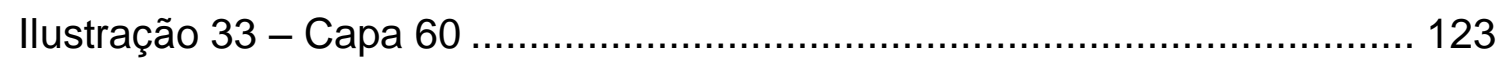

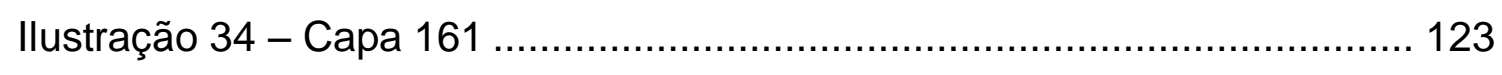

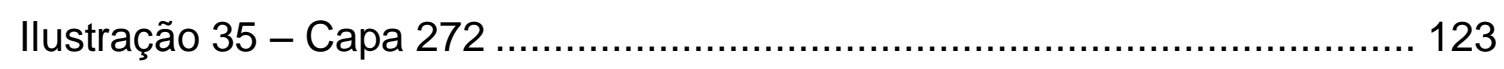




\section{INTRODUÇÃO}

\section{Tema}

A imprensa se caracteriza como um importante e poderoso meio de influência, atuando como formadora de opinião pública, construindo juízos, conceitos e apreciações a respeito dos diferentes aspectos da vida da população.

A presente dissertação insere-se no Programa de Filologia e Língua Portuguesa, seguindo a linha de pesquisa da Análise do Discurso, Análise da Conversação, Análise Crítica do Discurso, Pragmática e Sociolinguística.

Este trabalho tem por finalidade apresentar resultados de pesquisa sobre as marcas da oralidade em textos escritos, especificamente no texto jornalístico de jornais considerados "populares", cujo interesse maior se dá pela divulgação da notícia e aproximação com o público leitor.

A inter-relação entre fala e escrita, o texto híbrido ou o continuum são bastante característicos em jornais de formato popular, como é o caso do jornal Meia Hora de Notícias, elemento do trabalho. Pretende-se discorrer sobre aspectos da oralidade na linguagem jornalística, especificamente nas manchetes produzidas no citado jornal, analisando de modo descritivo e interpretativo tais marcas da oralidade que demonstram a inventividade e a estratégia de simulação do redator ao usar, na escrita, fenômenos linguísticos que estão ligados à língua falada. 
Assim, ao considerar a presença da oralidade, este trabalho propõe-se a verificar de que maneira a oralidade colabora como estratégia de aproximação do jornal com o leitor.

Para esta dissertação, foi feita a análise do jornal Meia Hora de Notícias, vulgo "Meia Hora". O Meia Hora de Notícias é um jornal do Rio de Janeiro, parte do grupo O Dia. Trata-se de um tabloide popular, com o custo de $\mathrm{R} \$ 0,70$ (Setenta centavos de Real). Tem de 32 a 44 páginas, é matutino e tem como objetivo ser de fácil compreensão, utilizando linguagem acessível e coloquial.

O formato do jornal é o tabloide, formato em que as páginas possuem aproximadamente a metade do tamanho das páginas de um formato tradicional de jornal impresso, o standard.

O jornal tem alcançado projeção em diferentes setores da mídia, sobretudo pelo projeto gráfico de suas capas, consideradas criativas e irreverentes e pelas manchetes. Os seus títulos e manchetes concentram grande foco de atenção dos leitores e os atraem, também, por causa de suas capas, que assim como as propagandas de produtos, chamam a atenção do público por conta de suas cores e imagens.

\section{Justificativa}

O interesse em estudar a oralidade na imprensa escrita deve-se, especialmente, à grande representação de fenômenos linguísticos da fala que ocorre de certa data para cá, nesse tipo de publicação.

O estudo justifica-se pela necessidade de uma análise que consiga demonstrar como o corpus escolhido para esta pesquisa tende a "reconstruir" a 
oralidade a fim de gerar proximidade com o público leitor. A importância desse trabalho se dá pelo dinamismo da língua e a intensa troca entre o oral e o escrito; essa troca faz da linguagem jornalística uma mistura entre o formal e o informal como maneira de envolver o maior número possível de leitores.

Para tanto, recorre-se a teóricos que apresentam conceitos referentes a questões de língua, linguagem, discurso e oralidade.

Acredita-se que este trabalho possa colaborar com os estudos relacionados à oralidade na mídia escrita, com base nos textos jornalísticos da mídia popular escrita.

\section{Objetivos}

\section{Objetivos gerais}

São objetivos gerais deste trabalho:

- compreender a construção da oralidade no jornalismo popular com base nas capas do jornal Meia Hora de Notícias.

- demonstrar de que modo os aspectos e fenômenos da oralidade se manifestam no texto jornalístico como estratégia de aproximação do leitor.

\section{Objetivos específicos}

São objetivos específicos deste trabalho:

- delinear as particularidades da linguagem do jornalismo popular. 
- verificar a relação entre língua falada e língua escrita, utilizando para tal o conceito de texto híbrido de Urbano (2006) continuum tipológico proposto por Koch e Oesterreicher (1985, 2007), Marcuschi (2008).

- analisar as marcas de oralidade presentes no jornal Meia Hora de Notícias com base nos níveis discursivo e linguístico.

- compreender tais marcas de oralidade como estratégias de aproximação do leitor.

\section{Metodologia}

Quanto à metodologia de pesquisa, consideramos adequado, do ponto de vista da abordagem, a abordagem qualitativa, considerando a relação entre o sujeito e o mundo e analisando os dados indutivamente. Do ponto de vista dos procedimentos técnicos da pesquisa, realizamos a pesquisa bibliográfica e documental.

Primeiramente, foi feito um levantamento para a composição do corpus, para, com base nos dados coletados, poder realizar a projeção de estudos teóricos.

Faz-se, no entanto, um estudo empírico, de natureza qualitativa do corpus composto por capas do jornal Meia Hora de Notícias. A coleta de dados para constituição do corpus inclui as capas de doze meses (outubro de 2012 a setembro de 2013). Com base na formação inicial do corpus, são observadas as capas coletadas, podendo-se obter alguns dados relevantes para a futura análise e responder a perguntas, como: quais são os principais temas tratados 
pelas capas do jornal? Em todas as capas há marcas de oralidade? Qual é o número de manchetes e títulos de notícias que trazem marcas de oralidade?

Mediante a análise do material coletado, traça-se um perfil do jornal Meia Hora de Notícias e do seu leitor, o que propicia analisar como ocorre a escolha pela leitura do texto jornalístico e a busca pela informação. $O$ intuito da análise é contextualizar o jornal, observando a linguagem empregada, tratando conceitos referentes à linguagem jornalística e definindo o conceito de manchete e título de notícia.

Sobre os conceitos de manchete e título de notícia, fundamentamo-nos em Bakhtin, 1997; Marcuschi 2005 e Takazaki, 2004. Primeiramente, conceituam-se gêneros do discurso e, na sequência, são explorados seu conteúdo temático, estilo e construção composicional.

Para que se possa responder às perguntas da pesquisa, é feita, pois, uma abordagem empírica indutiva, conforme descrita por Levinson (1983). São apresentadas as teorias utilizadas para fundamentar as discussões e análise. Observam-se, então, as diferenças entre as modalidades falada e escrita, os pressupostos teóricos que ajudaram a caracterizar os conceitos de oralidade e os elementos de oralidade na escrita.

Com base no referencial teórico, faz-se a análise do corpus, consistindo, entre procedimentos, na tabulação das manchetes, dividindo-as em temas, dos quais são destacadas as manchetes inseridas na tríade temática: violência, futebol e sexo. Com a motivação, descrição e análise do corpus, passa-se ao levantamento das ocorrências linguísticas nos níveis: discursivo, fonético, morfológico, sintático e lexical. 
A análise completa do corpus confirma as hipóteses tecidas neste projeto, comprovando marcas da oralidade como estratégia de aproximação com o público leitor.

\section{Estrutura da dissertação}

A fim de desenvolver nossos estudos, dividimos esta dissertação em duas partes. A primeira parte, teórica, dividida em quatro capítulos e a segunda, analítica, com um capítulo referente à análise do corpus.

Na primeira parte, dividida em quatro capítulos, tratamos, no capitulo inicial, sobre a relação entre língua falada e língua escrita, abordando-as a partir do que é a língua falada e a língua escrita prototípica e a relação entre as mesmas, o que faz com que entrem no continuum.

No segundo capítulo, contextualizamos o jornalismo, discorrendo sobre sua trajetória histórica. Abordamos, também, a dicotomia: jornal de referência versus jornal popular. Tratamos, ainda, com o intuito de contextualizar o corpus e situar o leitor, a linguagem jornalística e a estrutura do jornal.

No terceiro capítulo, apresentamos a questão do gênero discurso, inicialmente discorrendo sobre os gêneros primários e secundários, logo após apresentamos os elementos do gênero e nossas definições sobre os gêneros abordados nesta dissertação: o gênero capa e o gênero manchete.

No quarto capítulo apresentamos o corpus desta pesquisa, o jornal Meia Hora de Notícias contextualizando-o como jornal popular e expondo suas peculiaridades enquanto jornal que utiliza marcas de oralidade nas suas manchetes. Neste capítulo também apresentamos o perfil do leitor do jornal. 
A segunda parte desta dissertação é reservada à análise do corpus. Nossa análise foi dividida em duas partes principais: A análise em nível pragmático/discursivo, que contém cinco subdivisões e a análise em nível Linguístico, com quatro subdivisões.

Após a análise apresentamos a que conclusões chegamos ao final de nossos estudos. 


\section{PARTE I - FUNDAMENTAÇÃO TEÓRICA}

\section{CAPÍTULO 1 - DA FALA PARA A ESCRITA - DISCURSO E ORALIDADE}

Neste capítulo, tratamos dos conceitos relativos à língua escrita, falada e como não podem ser tratadas dicotomicamente como estando em polos opostos, pois em diversas ocasiões se aproximam o que cria o continuum.

\subsection{Estágio da Questão}

Para a análise do corpus, nossos estudos fundamentam-se em conceitos teóricos da Análise do Discurso, Análise da Conversação, Sociolinguística e Pragmática, consultando os trabalhos de autores, como: Marcuschi (1993, 1995, 2004 e 2007), Koch e Oesterreicher (1985, 2007), Charaudeau $(2007,2008)$, Koch $(1997,2008)$, Ong (1998), Preti $(1983,2004)$, Dias (1996), Urbano (1998, 2000, 2006 e 2011), Fávero (2009). Tais autores pesquisaram e desenvolveram profundos e perspicazes estudos sobre as relações entre a fala e escrita, essenciais para nosso trabalho.

Quando pensamos nos fenômenos relacionados à oralidade, precisamos ter em mente a língua falada e a língua escrita, não como modalidades em polos opostos e variações estanques. Precisamos ter claro o conceito de que no interior dessas modalidades há variações, que podem ser causadas pelos usos da linguagem enquanto práticas sociais ou por suas condições de produção. 
Segundo Marcuschi (1995, p.13), "As diferenças entre fala e escrita se dão dentro do continuum tipológico das práticas sociais e não na relação dicotômica de dois polos opostos". Sobre tal oposição, Marcuschi (2007) explicita que as relações entre fala e escrita precisam ser ponderadas na amplitude das práticas comunicativas e dos gêneros textuais. Para o autor, não se podem analisar tais relações de modo dicotômico, pois cada variante tem suas particularidades.

Sobre tais particularidades, Halliday (1985) aponta, por exemplo, entre outros argumentos, que o texto escrito possui maior densidade lexical e o texto falado, por outro lado, maior complexidade sintática. Assim, "fala e escrita apresentam tipos de complexidade diferentes" (Koch, 1997).

O contexto é determinante para a escolha da utilização da fala ou da escrita. Para Halliday (2002, p. 340), a fala e a escrita como formas de discurso são geralmente associadas a dois pontos modais no contínuo, da linguagem espontânea até a auto-monitorada, entendendo o discurso espontâneo como o, comumente, falado e o discurso auto-monitorado como o escrito.

A fala e a escrita, de acordo com Marcuschi (2007, p.35), "mantêm complexas relações com as representações e as formações sociais". A fala e a escrita são formas de representação cognitiva e social que se confirmam por intermédio de práticas particulares, deste modo não se considera uma superior a outra.

Para se categorizar os diversos tipos de texto que se apresentam ao longo do contínuo, Koch \& Oesterreicher (1990, apud Koch, 1997, p.61) aconselham "a utilização, além do critério do meio, oral ou escrito, do critério da 
proximidade / distância (física, social, etc.)". Pois, de acordo com Koch (2008), as características de uma ou outra forma de linguagem não são exclusivas. Podemos observar as características da fala e da escrita neste quadro proposto por Koch (2008), numa disposição dicotômica, de duas colunas, apenas por argumentação didática:

\begin{tabular}{|l|l|}
\hline Fala & Escrita \\
\hline Contextualizada & Descontextualizada \\
Implícita & Explícita \\
Redundante & Condensada \\
Não-planejada & Planejada \\
Predominância do "modus pragmático" & Predominância do "modus sintático" \\
Fragmentada & Não-fragmentada \\
Incompleta & Completa \\
Pouco elaborada & Elaborada \\
Pouca densidade informacional & Densidade informacional \\
Predominância de frases curtas, simples & Predominância de frases complexas, com \\
ou coordenadas & subordinação abundante \\
Pequena frequência de passivas & Emprego frequente de passivas \\
Poucas nominalizações & Abundância de nominalizações \\
Menor densidade lexical & Maior densidade lexical \\
\hline
\end{tabular}

Quadro 1 - Fala x escrita - Koch (2008) 
Urbano (2006, p. 32) também faz uma leitura de Koch e Oesterreicher (1985), e propõe um esquema, acrescentando sua visão e novos exemplos, a saber:

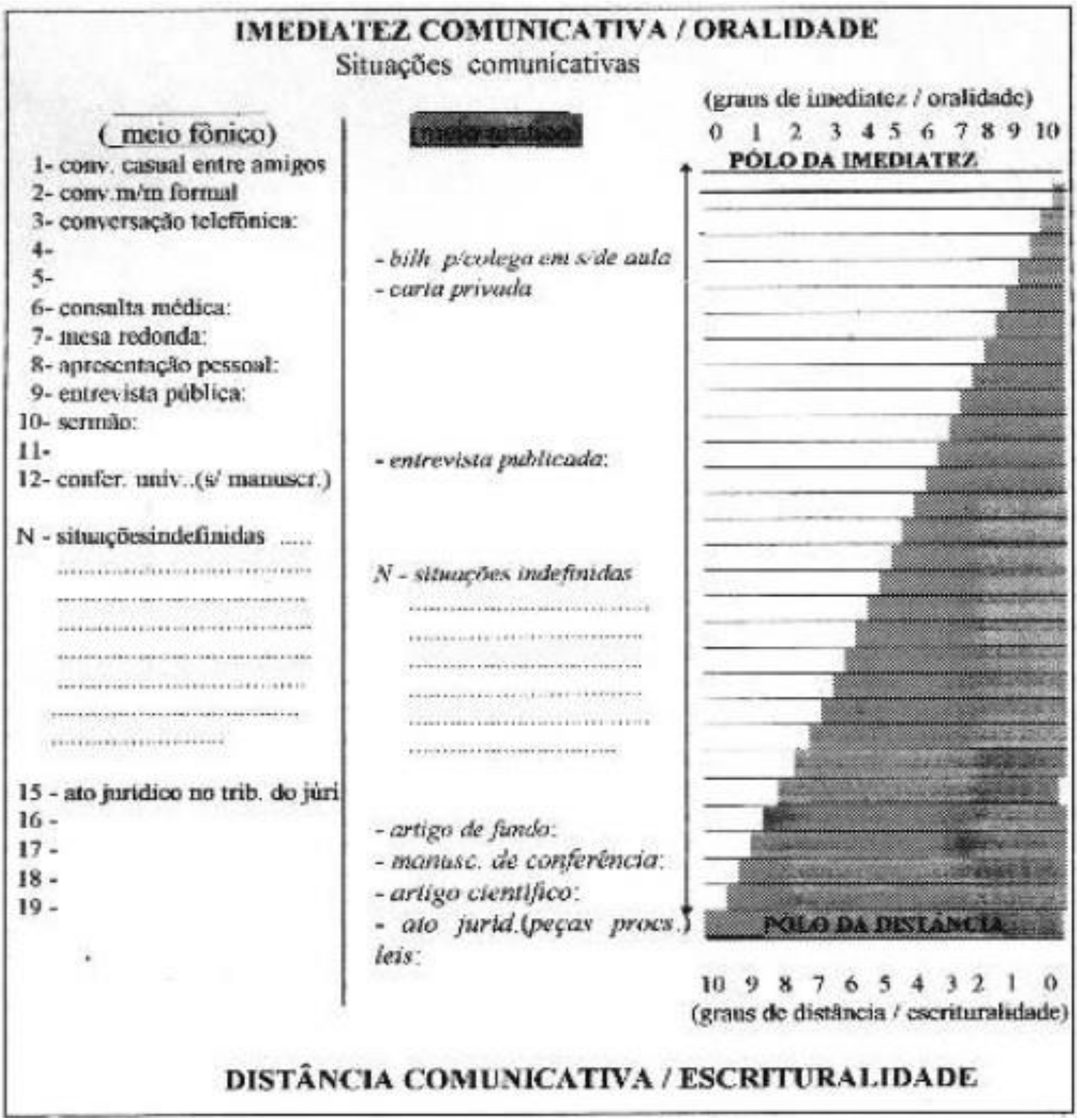

Quadro 2 - Urbano (2006)

O gráfico, apresentado por Urbano (2006), possui três colunas, sendo duas delas relacionadas ao meio (fônico e gráfico) e a terceira referente à concepção, esta subdividida em dois triângulos opostos, delimitando, de um 
lado, o campo da imediatez/oralidade discursiva, e do outro, oposto, o que representa a distância/escrituralidade discursiva.

O mesmo autor, em obra mais recente (2011, p.41), afirma que, "língua falada e língua escrita não têm as mesmas formas, nem o mesmo modo e instrumentos de estruturação, embora pertençam, de maneira geral, ao mesmo sistema linguístico.". Por isso é necessário levar-se em conta o contexto interacional, as características e as condições de produção da língua falada e escrita para se ter clareza sobre os elementos que as diferem.

Quando pensamos no texto escrito, podemos afirmar sobre as condições de produção que não há participação direta do leitor em sua construção; desse modo, o escritor normalmente antecipa as réplicas do leitor para quem ele discorre. O distanciamento no tempo e no espaço entre escritor e leitor faz com que aquele tenha mais tempo para planejar, revisar ou modificar o que escreve.

\subsection{0 texto escrito}

Podemos resumir a definição do texto escrito como aquele que é produzido graficamente em um suporte físico, como o papel ou similar e recebida pelo interlocutor de modo visual. Já quanto à concepção, podemos inferir que o texto escrito seria aquele concebido com maior elaboração e cuidado quanto à forma verbalização e tematização.

A escrita, segundo Marcuschi (2007), é uma nova maneira de armazenar o conhecimento e poder expressá-lo com um controle formal que a fala não permitiria pela sua concomitância entre produção mental e expressão verbal. A 
escrita é a reprodução da língua por meio de signos gráficos. Trata-se de um código de comunicação de segundo grau com relação à linguagem, que por sua vez é um código de comunicação de primeiro grau, pois a fala se desenrola no momento e esvanece; já a escrita tem o suporte físico e gráfico, que a mantém.

Dubois e colaboradores (1978. p.586) partilham da ideia de texto escrito como "conjunto de enunciados linguísticos submetidos à análise: o texto é então uma amostra de comportamento linguístico que pode ser escrito ou falado". Na compreensão seguida por esses linguistas, o texto seria formado por um conjunto de enunciados, sem consideração, em princípio para com os componentes que extrapolam os limites do texto, como o contexto.

Halliday e Hasan (1976. p.293) quanto à concepção do texto escrito vão além, levando em conta o aspecto interativo do texto e entendendo-o como "uma unidade de uso da língua em uma situação de interação". Assim, o texto escrito seria algo mais bem pensado, não como uma unidade gramatical, mas antes como uma unidade de tipo diferente: uma unidade semântica. A unidade que o texto tem é a integração de sentido em contexto, uma organização que expressa o fato de que ele se relaciona como um todo com o ambiente no qual está inserido.

Ainda, a partir do parecer apresentado por Dubois e colaboradores, Marcuschi (2008. p.72) entende o texto não apenas como um "comportamento linguístico", mas uma "ação linguística", em que suas fronteiras estão vinculadas ao mundo em que surgem e funcionam, quer dizer, não pode ser analisado basicamente pela frase em si (morfossintaxe), mas necessita, na 
compreensão do autor, levar em consideração os elementos que abrangem a sua produção, o contexto e os interlocutores.

Ong (1998, p.24) formula uma ideia, que, em princípio, não tem pleno consenso:

Sem a escrita, o espírito letrado não conseguiria nem poderia pensar como pensa, não só quando se engaja na escrita, mas também quando expressa seus pensamentos na oralidade.

Para Marcuschi (2008), o texto nasce das "ações sociais", das relações que possuímos com as outras pessoas. O autor adota uma perspectiva sociodiscursiva, na qual a língua, seja falada ou escrita, não acontece de modo descontextualizado, mas sim como produto das relações que temos uns com os outros e dentro de um contexto. Assim, o texto pode ser definido como uma tríade na qual se unem ações linguísticas, sociais e comunicativas. Adotando por base os princípios da Linguística Textual, o texto possui algumas especificidades que precisam ser levadas em consideração para uma análise adequada. Marcuschi $(2008$, p. 80) explicita tais especificidades:

- O texto é visto como um sistema de conexões entre vários elementos, tais como: sons, palavras, enunciados, significações, participantes, contextos, ações, etc.;

- O texto é construído numa orientação de multissistemas, ou seja, envolve tanto aspectos linguísticos como não linguísticos no seu processamento (imagem, música) e o texto se torna em geral multimodal;

- O texto é um evento interativo e não se dá como um artefato monológico e solitário, sendo sempre um 
processo e uma coprodução (coautorias em vários níveis);

- O texto compõe-se de elementos que são multifuncionais sob vários aspectos, tais como: um som, uma palavra, uma significação, uma instrução, etc. e deve ser processado com esta multifuncionalidade.

Assim, pode-se afirmar que um texto não é produzido nem pode ser compreendido apenas no plano da linguagem, há outros elementos inerentes formadores de um texto, como a cultura, a história, a sociedade, os sujeitos interlocutores, etc. Esses elementos serão retomados e servirão de base para delimitar os critérios de textualidade apresentados, que não devem ser entendidos como "princípios de boa formação textual”, pois não existe uma "receita" única e pronta que deve ser seguida na produção de um texto, ou seja, não significa que não respeitando algum (ou até mesmo mais de um) dos critérios apresentados, não se tenha um texto. Segundo Marcuschi (2008, p.81), "o que faz de um texto ser um texto é a discursividade, inteligibilidade e articulação que ele põe em andamento" e que aparecerão sempre nas condições particulares de produção de cada texto. Os critérios de textualidade são, portanto, uma tentativa de apontar as relações linguísticas, sociais e cognitivas (que não são estanques e paralelas) envolvidas na construção textual.

Marcuschi (2008) propõe o seguinte esquema em que apresenta a distribuição dos critérios de textualidade: 


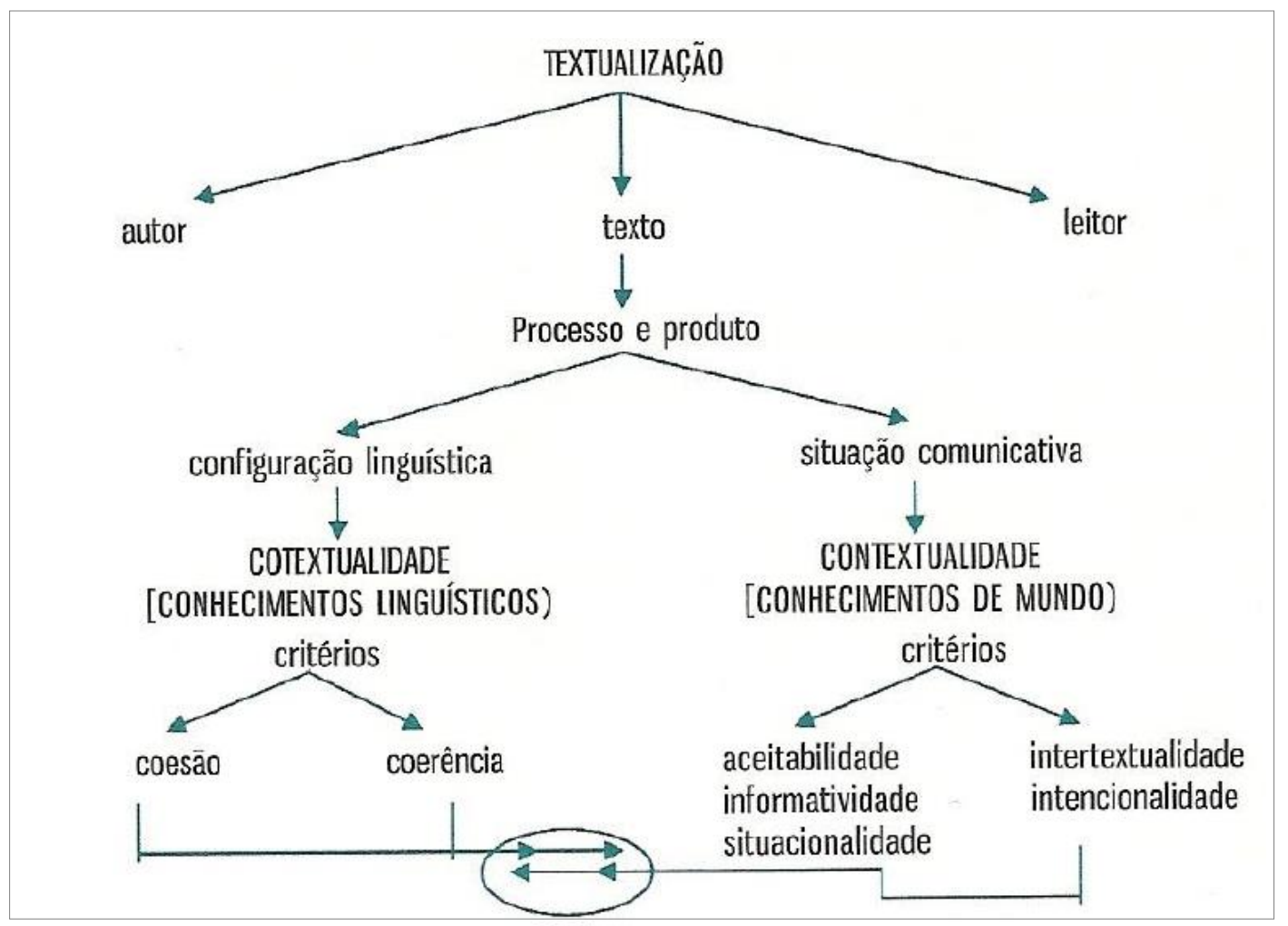

Quadro 3 - Marcuschi (2008)

Destacamos que o texto é uma unidade linguística de qualquer extensão (Val, 2006, p.03), de modo que uma palavra pode ser suficiente para estabelecer a comunicação entre os interagentes da troca comunicativa, pois equivale a outros textos, dotada de "textualidade" ou "textura", quer dizer, do ingrediente necessário à existência do texto.

Koch e Travaglia (1993) dizem ser a "textualidade” ou "textura”: “(..) o que faz de uma sequência linguística um texto e não uma sequência ou um amontoado aleatório de frases ou palavras", portanto, a responsável pelo fato de o texto ser aquilo que é.

Val (2006, p.05) compartilha da mesma ideia e acrescenta, com base em Beaugrande e Dressler, que a textualidade implica sete fatores, a saber: a intencionalidade, a aceitabilidade, a situacionalidade, a informatividade, a 
coesão, a coerência e a intertextualidade, conhecidos como os "fatores pragmáticos da textualidade", dos quais trataremos na sequência.

A escrita está vinculada à escolaridade; é uma técnica complexa que requer destreza e condição motora do indivíduo em sua aquisição. Contudo, não se podem separar as duas modalidades: fala de um lado e a escrita de outro, como se fossem duas realidades distintas e situadas em dois extremos. As relações entre elas são extensas e, ao contrário do que muitos pensavam, há mais semelhanças do que contrastes entre a língua falada e a língua escrita.

Pode-se dizer que a oposição entre as duas modalidades concentra-se no contexto, no texto e na funcionalidade; uma conferência oral, por exemplo, está mais próxima de um texto escrito acadêmico pela utilização de vocabulário específico, técnico, culto, até mesmo erudito, e por construções frasais complexas, com grande número de orações subordinadas, enquanto, diferentemente, conversas on-line, que são escritas, por exemplo, assemelham-se mais a um bate-papo entre amigos numa mesa de bar, em que há frouxidão na sintaxe, vocabulário limitado, construções frasais simples, frequentemente articuladas por: e e mas que, na linguagem falada funcionam, muitas vezes, mais como marcadores conversacionais do que como conectivos.

Há comunicações escritas que são intermediárias, já que se situam num continuum entre a fala e a escrita em termos de concepção: são cartas familiares, mensagens eletrônicas. São textos que estão a meio caminho do que é característico da fala e da escrita. 
Assim, apesar de a língua falada ter natureza distinta da língua escrita, elas não são estanques, havendo influências de uma sobre a outra. Marcuschi (2001, p.18) elucida que qualquer povo tem tradição oral, mas apenas alguns têm a tradição escrita que acaba sendo mais estimada socialmente do que a fala. Todavia, esse autor mostra a relevância que cada modalidade possui na sociedade, não havendo primazia de uma sobre a outra: Contudo, mais urgente (e relevante) do que identificar primazias ou supremacias entre oralidade e letramentos, e até mesmo mais importante do que observar oralidade e letramentos como simples modos de uso da língua, é a tarefa de esclarecer a natureza das práticas sociais que envolvem o uso da língua (escrita e falada) de um modo geral. Essas práticas determinam o lugar, o papel e o grau de relevância da oralidade e das práticas do letramento numa sociedade e justificam que a questão da relação entre ambos seja posta no eixo de um contínuo sócio-histórico de práticas. Esse contínuo poderia ser traduzido em outras imagens, por exemplo, na forma de uma gradação ou de uma mesclagem.

Urbano (1998, p.131) explica essas situações nas quais fala e escrita compõem textos que se acionam:

Há, na verdade, textos escritos que se parecem com "falas", dada a presença neles de marcas de oralidade e de linguagem popular. Isso acontece, ou por ignorância e despreparo daquele que escreve em relação às normas da língua escrita, ou por uma questão consciente de estilo. $O$ inverso também pode ocorrer: textos falados que reproduzem uma estruturação frásica e cuidados próprios da língua escrita. Aqui o fato se explica, entre outras razões, pelos hábitos linguísticos arraigados, adquiridos 
por força de vários fatores, e transferidos natural e inconscientemente para o uso da fala diária.

Sobre esse fato, outro aspecto pode ser notado: o de que todo usuário da língua, num contexto de comunicação, para entender seu interlocutor e ser entendido por ele, necessita entender a adequação de assunto e de linguagem. Se isso não ocorrer, há o risco de a comunicação não ser instaurada com eficácia. $\mathrm{Na}$ escrita, esse fato também pode se repetir se o escritor ou o redator não tiver receptividade do seu texto pelo leitor. Quanto maior o grau de escolaridade, menor ou quase nenhum traço de oralidade terá o texto; quanto menos escolaridade possuir o leitor, maior será o grau de oralidade. Isso em jornais tradicionais que têm público mais escolarizado e podem estruturar suas informações em textos mais formais e complexos. Jornais populares, com público de nível cultural mais baixo, fazem uso de expressões recorrentes na língua falada e têm estruturação frasal mais simples. Esses aspectos linguísticos são fenômenos habituais nesse tipo de publicação.

Tomemos como exemplo manchetes publicadas no jornal Folha de $S$. Paulo, $1^{\text {a }}$ página, e no Jornal da Meia Hora de Notícias; ambas publicadas no dia 14 de setembro de 2014. As capas tratam do tema violência: a primeira trata de um ataque violento ocorrido na cidade de Campinas; já a segunda capa trata de golpes praticados por mulheres em festas. 


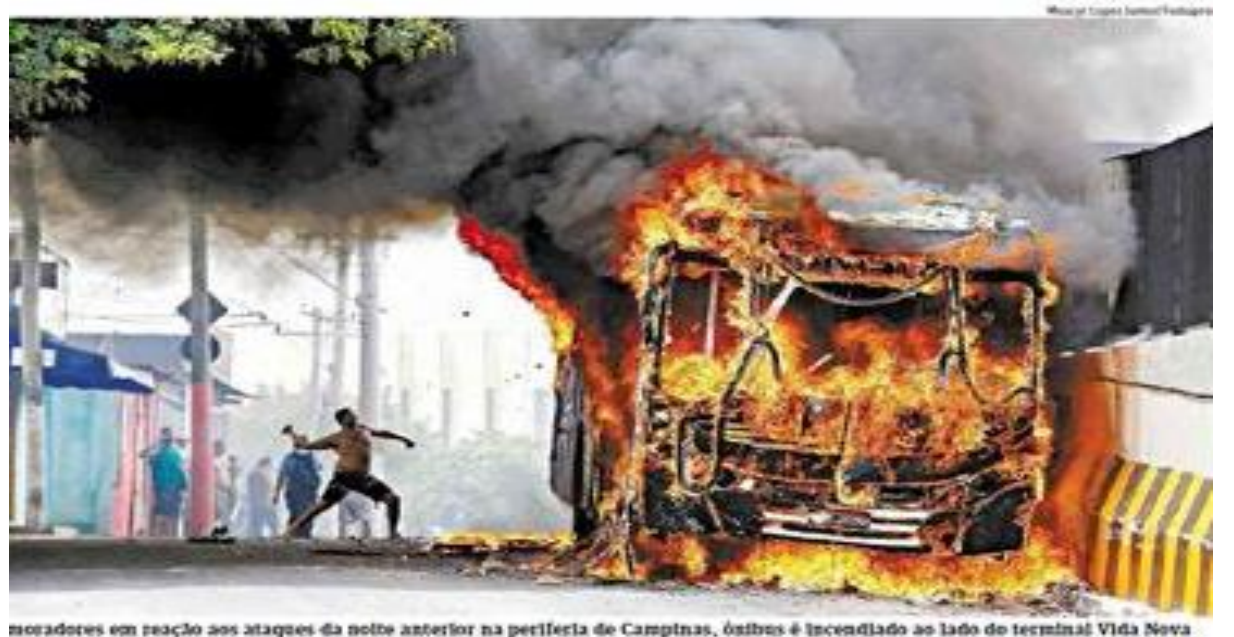

Em 5 ataques, 12 homens
são mortos em Campinas

$$
\text { Ilustração } 1 \text { - Folha de S. Paulo (14/09/2014) }
$$

"Em 5 ataques, 12 homens são mortos em Campinas" (Folha de S.Paulo).

O registro linguístico empregado é o padrão culto, de estruturação clássica de frase na voz passiva. É uma reprodução frásica típica da língua escrita, sem qualquer vestígio que a identifique com alguma característica da língua falada.

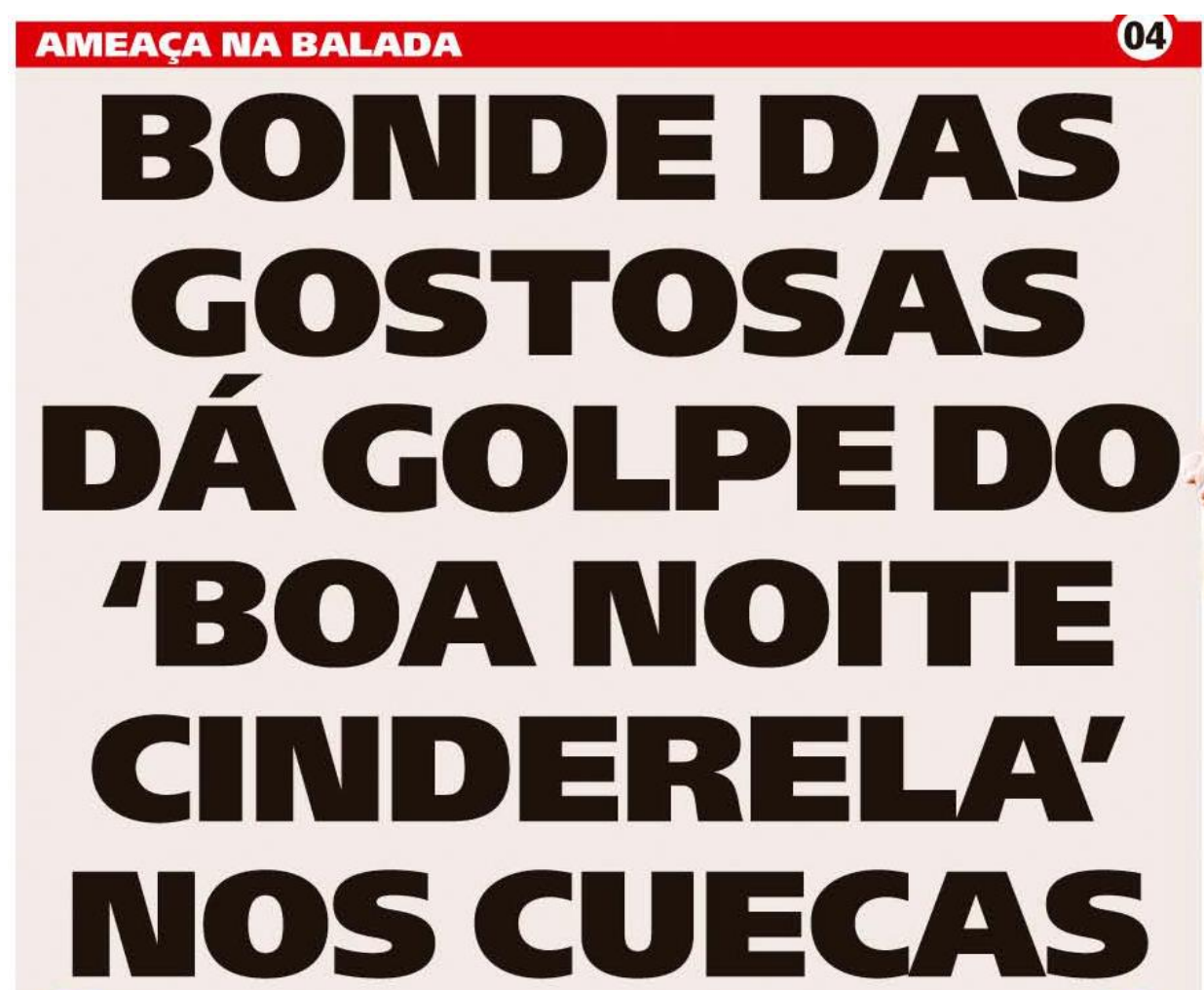

Ilustração2 - Meia Hora de Notícias (14/09/2014) 
Na manchete "Bonde das gostosas dá golpe do 'boa noite cinderela' nos cuecas" do Meia Hora de Notícias, por outro lado, o registro linguístico utilizado é o da fala popular, sem preocupação com o vocabulário refinado. Esse texto escrito apresenta fortes marcas da oralidade que o aproximam de uma linguagem menos preocupada com as regras da gramática e, ao fazer a escolha desse registro, típico das camadas menos escolarizadas da sociedade, o jornal se identifica com o seu leitor, procurando chamar-lhe a atenção por meio da linguagem, para esse contexto de violência.

\subsection{0 texto falado}

A língua falada é uma vantagem e um patrimônio do ser humano; é a forma mais natural e competente da comunicação humana. Por meio dela, o usuário entra em contato com o mundo e com o outro. O modo mais comum de se comunicar e interatuar é pela conversação, cujos interlocutores estão em presença.

Para Ong (1998, p.15), essa dimensão que a língua falada representa é um fenômeno próprio da existência humana, ele aponta outros fatos que se unem a ela para dar eficiência ao diálogo:

Os seres humanos comunicam-se de inúmeras maneiras, fazendo uso de todos os seus sentidos: tato, paladar, olfato e especialmente visão, assim como a audição. Algumas comunicações não-orais são extremamente ricas - a gestual, por exemplo. Contudo, num sentido profundo, a linguagem, o som articulado, tem importância capital. Não apenas a comunicação, 
mas o próprio pensamento está relacionado de forma absolutamente especial ao som. Todos nós ouvimos dizer que uma imagem vale mil palavras. No entanto, se essa afirmação é verdadeira, por que ela é feita com palavras? Porque uma imagem vale mil palavras apenas em certas condições especiais - que comumente incluem um contexto de palavras em que está situada a imagem.

No cotidiano, a língua falada e a língua escrita estão unidas, estabelecem entre si uma união sem limites claros.

Urbano (2006, p.42) afirma que a língua falada caracteriza-se quanto ao "meio" e a "concepção" de produção de textos, da seguinte forma a língua falada:

A 'língua falada prototípica", a língua falada propriamente dita, seria então uma atividade social verbal de produção de texto. É exercida oralmente, graças a um sistema de sons articuláveis, no tempo real, em contextos naturais de produção, incluídos outros elementos de natureza corporal, que preenchem, em teoria, "todas as condições linguístico-textual-discursivas" concebidas para um texto falado. Em outras palavras, possui, do ponto de vista medial, caráter fônico, e do ponto de vista concepcional, as condições de comunicação, que vão permitir as "estratégias de formulação" e imprimir as "marcas de verbalização" ideais de um texto essencialmente falado.

Em relação à fala há inúmeros elementos adjacentes, que se unem a tal ação, como:

- Possuir planejamento prévio limitado, feito de modo rápido;

- Ser conduzida de modo espontâneo;

- Possuir elementos paraverbais;

- Ser fragmentada; 
- Haver interação, entre outras.

$\mathrm{Na}$ fala, não há planejamento prévio total, apenas parcial, pois ela é produzida à medida que se fala. Pode-se pensar apenas sobre o tema ou 0 assunto, mas o modo de sua realização ao longo do desenvolvimento da conversação não pode ser antecipado. Os falantes não podem prever as hesitações, as interrupções, as repetições, as mudanças do próprio assunto. Urbano (1998, p.134) explica que o planejamento da fala é mutável, que seria difícil sua concepção totalmente planejada e imutável. Porém, logo que o ato conversacional se desenvolve pode acontecer, dependendo do(s) tema(s) abordado(s), um replanejamento no qual se analisa a necessidade de se reestruturar a organização discursiva do texto para que os interlocutores prossigam a colaborar entre si e a participar da conversação.

$\mathrm{Na}$ fala, não há preocupação excessiva com a gramática, de tal modo que mesmo não tendo conhecimento intenso acerca das normas. Preti (2004, p.125) afirma que "a língua falada é organizada, não propriamente como a escrita, mas tem uma gramática própria que os falantes aprendem no uso diário e cujas categorias de análise diferem da gramática da língua escrita". As diferenças de organização são observadas, por exemplo, na estruturação das frases: na língua falada os períodos são simples ou com frases justapostas, surgem gírias, frases feitas, clichês, provérbios.

A produção da fala, também, ocorre de modo de distinto do texto escrito. A fala é marcada pela presença de dois ou mais interlocutores, cujo assunto da conversação é estabelecido em partes, levando-se em conta, além do aspecto sonoro, os situacionais. O texto falado é marcado pela espontaneidade, por se 
demonstrar acessível e explícito durante a sua construção por ser um ato de realização coletiva e também por apresentar caráter impreciso.

Ong (1998, p.51) explica como os recursos de organização do texto oral são importantes para que o locutor tenha controle sobre 0 assunto desenvolvido e como estratégia para manter o seu interlocutor atento:

A necessidade que sente o orador de prosseguir enquanto está repassando em sua mente o que dizer em seguida também favorece a redundância. No estilo oral, embora a pausa possa ser benéfica, a hesitação é sempre prejudicial. Por conseguinte, é preferível repetir algo, se possível engenhosamente, a simplesmente parar de falar enquanto se está à procura da idéia seguinte.

Marcuschi, porém, (1986, p.27) tem modo diferente de analisar as pausas, alongamentos e repetições, pois ele afirma que "uma hesitação, por exemplo, pode ser um convite à tomada de turno, e, por vezes, o ouvinte chega mesmo a concluir o turno do falante numa espécie de coautoria". Ele completa, dizendo que as hesitações servem na organização e planejamento interno do turno e dá ao falante a oportunidade de ele ganhar tempo para se organizar.

O planejamento parcial (ou o não planejamento) é uma das distinções marcantes da língua falada e confere-Ihe caráter fragmentário que se constata durante a construção do texto, mas não deixa de lhe dar espontaneidade e intuição que são típicas na fala que não apresenta modelos preestabelecidos, a não ser uma forte relação com o contexto.

No texto falado há um trabalho de colaboração entre os falantes que compõem em conjunto e concomitantemente, por isso não há momento para planejamento prévio; tal planejamento acontece ao mesmo tempo em que a 
ação dos falantes. Assim, conclui-se que a única etapa real de planejamento prévio de um texto falado é a temática; o seu desenvolvimento será executado de acordo com o contexto, das informações e do conhecimento de cada interlocutor.

Existem informações no texto falado que colaboram para que a conversação se instaure e se concretize. São elementos que servem como recursos de interação, de coesão e coerência. Denominam-se marcadores conversacionais, estes podem ser:

a) lexicalizados: mas, e, certo? , eu acho que, etc. e

b) os não lexicalizados: hum, hum, ah!

Além desses elementos, há as pausas, gestos, expressões faciais, mímicas. Urbano (1998, p.85) explica a funcionalidade que os marcadores conversacionais emprestam ao texto falado:

Esses elementos, típicos da fala são de grande frequência, recorrência, convencionalidade, idiomaticidade e significação discursivo-interacional. Mas, não integram propriamente 0 conteúdo cognitivo do texto. São, na realidade, elementos que ajudam a construir e a dar coesão e coerência ao texto falado, especialmente dentro do enfoque conversacional. Nesse sentido, funcionam como articuladores não só das unidades cognitivoinformativas do texto como também dos seus interlocutores, revelando e marcando, de uma forma ou de outra, as condições de produção do texto, naquilo que ela, a produção, representa de interacional e pragmático. Em outras palavras, são elementos que amarram o texto não só enquanto estrutura verbal cognitiva, mas também enquanto estrutura de interação interpessoal.

Assim, podemos afirmar que a fala é participativa e interacional. A realização da fala é algo dinâmico, nela há presença de frases mais simples, 
curtas e quase sempre organizadas em períodos simples ou compostos por coordenação. Tal fato se deve à falta de tempo para o planejamento da fala, pois o texto oral, como já mencionado, é planejado concomitantemente com a ação de falar. A língua falada é mais econômica, pois o contexto já está posto, oposto à escrita em que há certa necessidade de uma melhor explanação de ideias para o entendimento do leitor.

\subsection{0 texto híbrido - continuum}

Como observamos até aqui, embora existam muitas diferenças entre as modalidades falada e escrita da língua, há textos que estão na faixa do contínuo, como observa Marcuschi (1993, p. 71):

Não resta dúvida de que existem textos tipicamente orais e outros que são tipicamente escritos. Também é certo que há certos fenômenos que são mediados pela escrita e outros são mediados pela fala. As práticas sociais criam formas de transmissão do conhecimento apropriadas tanto à cultura como aos modos de produção. Estas duas classes de textos exibirão diferenças sensíveis entre si, mas os textos restantes estarão dentro da faixa de um contínuo. É até provável que não sejam muitas as diferenças essencialmente linguísticas e que a maioria delas seja de processamento, em função do tempo, das condições e dos meios de produção, além das diferenças do tipo de texto realizado.

Nesse sentido, também se posiciona Urbano (2006. p.42-44), propondo:

A "língua falada prototípica", a língua falada propriamente dita, seria então uma atividade social verbal de produção de texto. É exercida oralmente, graças a um sistema de sons 
articuláveis, no tempo real, em contextos naturais de produção, incluídos outros elementos de natureza corporal, que preenchem, em teoria, "todas as condições linguístico-textualdiscursivas" concebidas para um texto falado. Em outras palavras, possui, do ponto de vista medial, caráter fônico, e do ponto de vista concepcional, as condições de comunicação, que vão permitir as "estratégias de formulação" e imprimir as "marcas de verbalização" ideais de um texto essencialmente falado.

Por outro lado, a "língua escrita prototípica", a língua escrita propriamente dita, seria uma atividade social verbal de produção de texto. É executada graficamente, graças, basicamente, a um sistema de letras articuláveis, chamado alfabeto, complementado por sinais de pontuação, de acentuação, numéricos etc., que preenchem, em teoria, "todas as condições linguístico-textual-discursivas" concebidas para um texto escrito. Em outras palavras, possui, do ponto de vista medial, caráter gráfico e do ponto de vista concepcional, as condições de comunicação, que vão permitir as "estratégias de formulação" e imprimir as marcas de verbalização ideais de um texto essencialmente escrito.

Já no campo do continuum, não há como atribuir aprioristicamente classificações e denominações fixas, podendose falar de modo genérico, como já sugerimos antes, em texto "híbridos", ora mais próximos da imediatez ou da oralidade (dotados de marcas ou "signos de oralidade", no dizer de Borso (1997. p.127), consideradas as ressalvas feitas no início deste texto, ora mais próximos da distância ou escrituralidade (dotados de marcas que podemos conceber como verdadeiros signos da distância ou escrituralidade). Trata-se, nesse sentido, da mistura de elementos diversos que compõem um texto, ou seja, de verdadeiro amálgama textual.

Vemos, então, que as diferenças entre língua falada e escrita não acontecem de modo simplório. Assim, também afirma Charaudeau (2008) que 
diz não haver uma oposição clara entre a língua falada e a língua escrita. Para Charaudeau, tais separações são resultado da combinação particular dos componentes de cada situação de comunicação. Por isso, deve-se considerar fatores, como: se os interlocutores estão presentes; se o canal de comunicação é oral ou gráfico; e se a interlocução é concreta ou não. Com base nestes fatores, Charaudeau (2008) descreve duas situações de comunicação: dialogal e monologal.

Na situação dialogal os interlocutores estão presentes fisicamente e há uma condição favorável de comunicação, sendo o canal de transmissão oral e compreensível por ambos. Na situação monologal, os interlocutores não estão presentes fisicamente e o canal de comunicação pode ser oral ou gráfico. Nessa situação, o locutor não pode perceber imediatamente as reações do interlocutor, somente idealizá-las.

Estudos têm apontado a necessidade de um distanciamento da visão dicotômica sobre as relação entre fala e a escrita, pois ambas se aglutinam em torno de um intricado quadro de variação. Assim, pode-se confirmar a ideia de contínuo, pois podemos confirmar que não há diferenças essenciais e, sim, uma gradação nas relações entre as modalidades, o que remete ao caráter multifacetado dessas diferenças.

Por isso há dificuldade em distinguir se o discurso produzido deve ser considerado falado ou escrito. Um exemplo é a notícia de um telejornal, que aparece na forma falada, porém é a leitura de um texto escrito. Ou a publicação de uma entrevista, que originalmente foi produzida na forma oral, mas, ao ser publicada toma a forma escrita. 
No caso das notícias de jornais populares, elas trazem uma série de marcas em comum com a conversação espontânea, como a utilização de muitos pormenores, a presença da linguagem informal, a representação gráfica de sons (aliteração), gírias, provérbios populares, frases feitas, envolvimento, dentre outros. A utilização desses recursos da oralidade no texto do jornal popular torna a leitura mais envolvente e familiar, o que a aproxima da conversação espontânea. 


\section{CAPÍTULO 2 - JORNALISMO - CONTEXTUALIZAÇÃO}

No capítulo dois, apresentamos uma contextualização sobre o jornalismo, desde seu "nascimento" na Roma Antiga, passando por sua evolução com Guttemberg, seu desenvolvimento, expansão e o jornalismo no Brasil. Expomos, ainda, conceitos sobre o jornalismo de referência e o jornalismo popular, as características da linguagem jornalística, e por fim, a estrutura do jornal.

\subsection{Jornalismo: um percurso histórico}

A imprensa forma a opinião pública, constrói conceitos e ideologias sobre os diferentes aspectos do cotidiano. Por isso, caracteriza-se como um importante e poderoso meio de influência das classes dominantes sobre as massas populares. O jornalismo é uma representação discursiva da vida humana na sua diversidade de vivências e ideias. Assim, pode se afirmar que o jornalismo vai buscar a sua origem nos tempos mais remotos, quando os humanos começaram a transmitir informações e a contar histórias, fosse por uma questão de necessidade, por entretenimento ou ainda para preservação da sua memória para gerações futuras.

Desde a Roma Antiga, a transmissão da informação já era necessidade do homem, um boletim com anúncios do governo eram esculpidos em metal ou pedra e exibidos em locais de acesso público, era a Acta Diurna no ano 59 a.C. Data quando se estipula que tenha sido a criação do que conhecemos como jornal. 
Assim, podemos afirmar que o início do que conhecemos como jornalismo se deu na Antiguidade Clássica, sendo retomado na Idade Moderna, com o Renascimento, quando houve o desenvolvimento de condições técnicas e socioeconômicas. Estas ocorridas no século XIX devido ao aparecimento das impressoras e prensas, que permitiram a massificação dos jornais; a invenção de dispositivos de transmissão da informação à distância e as máquinas fotográficas.

Segundo o autor José Marques de Melo (2003), a diminuição das distâncias geográficas - graças a meios de transportes mais ágeis e baratos, também foram fundamentais para o desenvolvimento da imprensa. A partir dessa primeira precisão, houve uma necessidade social, política e econômica de um meio de comunicação que pudesse atender a sociedade, para a rápida troca de informações e ideias. Inicialmente, o surgimento de pequenas gazetas nos séculos $\mathrm{XV}$ e $\mathrm{XVI}$ atendendo, sobretudo aos habitantes das cidades e aos governantes. Após esse momento, os comerciantes da época precisavam de informações técnicas para a gestão de seus negócios e, por fim, os governantes buscavam acesso e forneciam comunicados para o ambiente político.

Formas elementares, que ainda não se encaixavam no jornalismo que conhecemos hoje, eram veiculadas na Europa. O conteúdo dessas gazetas, segundo Olson (Apud. Melo, 2003, p.20), era "descrever um crime, uma catástrofe, batalha ou morte importante, evitando notícias políticas e relatando apenas trivialidades, elaboradas para o divertimento solitário do leitor, de modo a escapar, por via das dúvidas, da censura oficial". Portanto, a base desses textos era um conjunto de expressões tipográficas aleatórias que não possuíam 
uma regularidade ou periodicidade como os meios de comunicação de hoje. Vale ressaltar que a opção de não periodicidade era uma forma de escapar da censura estabelecida na época. Segundo Rizzini (Apud. Melo, 2003, p.21), atividades jornalísticas em Portugal só aconteceram de forma sólida após a Revolução do Porto ocorrida no século XIX, ilustrando como a censura pressionava e impedia o avanço do jornalismo.

Assim, existiam duas vertentes: a primeira, clandestina, funcionando de modo ilegal por não passar pela censura, feita de forma artesanal; e a outra vertente, a oficial, aprovada pelo Estado, com um conteúdo obsoleto de notícias estrangeiras, isentas de críticas ao governo e com um cunho político e autoral inexistente.

Foi na França em 1788 que foi instaurado um decreto estabelecendo uma liberdade de imprensa, ainda que não completa, oferecendo um ambiente mais favorável para o surgimento de novos periódicos. Apesar disso, para a circulação desses periódicos, havia a obrigação de pagamento de impostos de valor considerável, conhecido como imposto do timbre, o que limitava o crescimento dessas atividades.

Após a tomada do controle do Estado pela burguesia, eliminando a censura prévia, mas tomando para si o controle das notícias, houve o favorecimento dos próprios negócios e jogos políticos. Apesar disso, o fim da censura proporcionou uma atividade de troca de ideias, defendendo pontos de vistas e expressão de opiniões. Outra vertente de um jornalismo mais informativo e ausente de opiniões próprias também obteve êxito, sendo aprovado pela burguesia e não arcando com o custo de enfrentá-la, como o jornalismo opinativo. 
No século XIX, o jornalismo informativo assume a posição maciça dentro da sociedade americana, tornando-se um produto mercantil como qualquer outro, ou seja, um negócio que exigia rentabilidade financeira. Com esse quadro, o jornalismo opinativo não desaparece, mas tem seu espaço reduzido, encaixando-se dentro dos editoriais.

Durante este período, os donos dos jornais advertiam severamente os jornalistas que insistiam em defender suas opiniões com a seguinte observação: se você quer escrever o que pensa, compre um jornal. Para o público, apregoava-se o mito da imparcialidade e objetividade do texto jornalístico, que busca encobrir os verdadeiros interesses da empresas e suas alianças econômicas e político-ideológicas (Lustosa, 1996, p.72).

O autor acrescenta ainda que essa técnica veio atender, também, às exigências da sociedade urbana da época, "quanto ao atendimento de suas necessidades de informação". E coincide, inclusive, com o início dos cursos de jornalismo, em nível universitário, uma vez que "o jornalismo passou a utilizar uma técnica que exigia um treinamento específico" (p.73).

\subsection{A imprensa no Brasil}

A imprensa chegou ao Brasil com a corte de D. João VI. Até então, qualquer atividade gráfica era proibida na colônia, assim como o ensino superior. Segundo Lage (2001), para alguns historiadores, tal limitação se 
atribui à falta de uma cultura nativa que pudesse fazer face à do colonizador ou ao receio de se firmar uma cultura autóctone.

Em junho de 1808, Hipólito da Costa, refugiado em Londres por causa de perseguições políticas, lançou o primeiro número do Correio Braziliense. Embora quase sempre movido por interesses mesquinhos, o jornal foi contra 0 absolutismo e a favor das liberdades políticas e das instituições civis. No entanto, o primeiro jornal editado e impresso no Brasil foi a Gazeta do Rio, publicado em 10 de setembro de 1808, o que marcou o início da imprensa no país.

O jornal era um porta-voz da corte, consistia basicamente de comunicados do governo e também publicava informes sobre a política internacional. Apesar de ser voltado para os interesses da coroa e da vida cortesã, a Gazeta do Rio lançou o hábito do consumo da informação periódica, já que era publicado duas vezes por semana. Na maioria das colônias, a imprensa surgia no Brasil dividida entre o oficial e o particular, entre a liberdade de expressão e a censura, entre o público e o privado.

O absolutismo da Coroa portuguesa não era mais capaz de se impor apenas pelas armas; precisava do aval da sociedade brasileira. Para isso, era preciso mantê-la informada e convencida da relevância de dar sustentação ao regime que naquele momento se instalava no Brasil. (Gontijo, 2004, p.278)

Ainda segundo Gontijo (2004), os jornais tinham um caráter panfletário e utilizavam o seu espaço para, quase sempre, defender as posições de seu proprietário. Tais jornais não tinham como intuito noticiar e sim produzir acontecimentos. A princípio pareciam saber que uma de suas finalidades era 
educar o povo, mas o que se via, no século XIX, era uma disputa radical, que resultava em redações jornalísticas bastante originais.

O jornalismo que era produzido por autores ligados à literatura trazia textos pretensiosos e pouco objetivos, associados a uma diagramação confusa que misturava assuntos desconexos na primeira página. De acordo com Gontijo (2004, p. 287), as notícias "eram encabeçadas por títulos curtos, mas seu conteúdo era superficial e entediante, sem subtítulos e lides, e desconheciam a forma de manchete já tão usada nos jornais americanos".

Outro fator a ser considerado em relação à imprensa do século XIX no Brasil é o que diz respeito aos critérios para a escolha das principais notícias, além da incapacidade de se adaptar a linguagem do jornal ao público-alvo. A imprensa se mostrava superficial e não existia o jornalismo investigativo nem uma apuração rigorosa, que eram critérios valorizados na América do Norte e na Europa.

Além de toda essa falta de objetividade, havia uma série de publicações de cunho social, como batizados, casamentos, aniversários, declarações de amor, fofocas e uma seção editorial chamada "a pedidos", que publicava qualquer coisa que fosse pedida, principalmente quando se falava mal dos outros.

Com o início do século XX, começaram as primeiras transformações na imprensa brasileira. Os jornais e revistas se transformaram em empresas e, com isso, a opinião do público passou a ser o foco do conteúdo jornalístico, já que os jornais não dependiam mais exclusivamente do Estado nem dos setores da economia e da política. O folhetim passou a ser substituído pelo colunismo, 
pelo artigo político, pelas entrevistas e, consequentemente, investia-se mais em informação, ainda que se objetivasse a opinião de modo imparcial.

Atualmente, a imprensa brasileira apresenta uma configuração bem diferente daquela do século XIX. A revolução tecnológica não só permitiu que a produção fosse massificada como também foi uma das responsáveis pela segmentação do mercado, possibilitando que o público buscasse a informação de modo personalizado, com diversas publicações voltadas para universos específicos.

\subsection{Jornalismo de "referência"}

O jornalismo de referência é um jornalismo que serve de referência para a informação, análise e produção de opinião. O público assume-se, desde a sua fundação, como um diário de referência que pratica um estilo que se enquadra no mesmo tipo de jornalismo praticado por outros periódicos de referência de todo o mundo.

No final do século XIX, começa a haver um aumento da literacia das populações, o que fez com o que o jornalismo adquirisse um novo formato.

Em geral, a história do jornalismo seguiu o padrão europeu ocidental de desenvolvimento profissional, sendo uma resposta à crescente alfabetização, ao aumento de riqueza e aos desenvolvimentos nas técnicas de comunicação e imprensa que a industrialização trouxe. (O'Boyle, apud Traquina, 2007. p.46). 
As lutas contra a censura, o contrato com repórteres e a prática da lei sobre a liberdade de imprensa, no final do século XIX, foram alguns dos fatores que cooperaram para uma alteração no modelo da imprensa.

A expansão da imprensa veio com o crescimento do que era designado «imprensa respeitável», os grandes jornais diários como The Times. A imprensa respeitável era ela própria um produto da industrialização em Inglaterra (Traquina, 2007. p.46).

Os leitores passaram a ser mais exigentes com a informação que queriam consumir, e o aumento de anunciantes e do conhecimento acadêmico permitiu que os jornais se tornassem instituições mais sólidas e autossustentáveis, adquirindo profissionais. "Estabeleceu-se a ideia de que a primeira função de um jornal era noticiar com exatidão e não distorcer as notícias com propósitos políticos" (Traquina, 2007. p.47). A noção descrita por Traquina (2007) é a percursora de um jornal de referência: construir a realidade por meio de jornalistas qualificados, reproduzindo a informação averiguada e com exatidão, sem dependências de qualquer ordem.

O século XIX marca então a gênese dos ideais do jornalismo de referência, também ligados à liberdade de imprensa. Os leitores são pessoas mais alfabetizadas, interessadas e informadas que exigiam uma imprensa mais elitista. Como refere Sousa (2008. p.105), 
O século XIX foi, também, como se disse, um século de expansão das ideias liberais e do espírito burguês, a que se associa a ideia da liberdade de imprensa. Esse fenômeno levou ao florescimento da imprensa política (que, entre outras designações, também pode ser denominada opinativa, combativa ou "de partido" "partypress"), apesar de, frequentemente, essa imprensa ser simultaneamente noticiosa, literária e divulgadora de ideias e descobertas. Era uma imprensa de elites, e para as elites alfabetizadas e envolvidas no combate político e ideológico, uma imprensa cara, inacessível aos cidadãos comuns.

O tipo de imprensa citada por Sousa (2008) era predominante durante a primeira metade do século XIX na Europa e América Latina enquanto que, nos Estados Unidos, na mesma altura, o cenário jornalístico dominante eram os jornais populares que, de acordo com Sousa (2008. p.105), eram:

$$
\begin{aligned}
& \text { Jornais predominantemente noticiosos, baratos, } \\
& \text { politicamente independentes, com um discurso acessível, } \\
& \text { direcionados para as pessoas comuns, encarados } \\
& \text { essencialmente como negócio empresarial, que } \\
& \text { começaram a competir com os jornais de elite } \\
& \text { dominantes. }
\end{aligned}
$$

$\mathrm{Na}$ Europa e América latina, dava início o conceito de imprensa de referência. Ela promovia um jornalismo independente, livre, isento, elitista e factual; já nos Estados Unidos, nascia um jornalismo popular: tendencioso, parcial e acessível às massas. No entanto, esses dois polos jornalísticos não se neutralizavam, convivendo sem que um ofuscasse o outro. Esses dois polos, de um lado o jornalismo popular e de outro a imprensa de referência, 
estão hoje igualmente vivos no mundo do jornalismo. Sousa (2008. p.152), aponta, através de Schudson (1978. p.88), as principais diferenças:

Por contraposição ao Novo Jornalismo, emotivo e que tudo promovia à condição de insólito ou sensacional, os jornais e revistas "de qualidade" procuravam apelar à razão, oferecendo uma informação mais rigorosa, "objetiva" e profunda, por vezes analítica, mais sóbria no grafismo, mais voltada para o público do que para 0 privado (ou seja, orientada para o interesse público e não para o interesse do público) e mais devotada à exploração estrutural dos grandes temas da política, da economia, da sociedade e das relações internacionais do que à superficial menção a crimes, escândalos e a outros atos singulares e ações desviantes.

A imprensa de referência possui as qualidades da partypress e as qualidades da imprensa de negócios do século XXI. Tais como: rigor, exatidão, sobriedade gráfica e de conteúdos, análise e opinião, independência, objetividade, seriedade, é elitizado e respeitável. Esses são termos usados para caracterizar jornais que se assumem como publicações de referência, em oposição às publicações populares ou sensacionalistas. Pois, pautam-se pelo rigor, exatidão, independência e objetividade no seu cotidiano, eliminando de suas páginas o sensacionalismo, que poderíamos distinguir como: as notícias sobre sentimentos, emoções, crimes insólitos, etc.

Assim, podemos descrever algumas características fundamentais dos jornais de referência: o rigor e exatidão da informação que tratam e veiculam; a tiragem e circulação; a credibilidade junto aos leitores; a cobertura de notícias a nível local, nacional e, sobretudo internacional; seu público alvo - geralmente 
intelectuais ou pessoas com certo nível de cultura; a análise política; a responsabilidade social e cultural que assumem perante os leitores; a sensatez e procura incessante pela verdade, pelo compromisso pelo serviço público, pela rejeição de abordagens sensacionalistas; a influência na sociedade e perante os outros jornais; a forma rigorosa como a informação é redigida e pelo tipo de pessoas que constroem e contribuem com o jornal (se são jornalistas de formação, escritores, filósofos, ensaísticas, críticos, entre outros).

\subsection{Jornalismo "popular"}

Desde o fim do último século, sucederam-se lançamentos de novos modelos de jornais populares no Brasil. Jornais direcionados, principalmente, à classe $\mathrm{C}$, tal escolha deveu-se ao seu potencial de consumo que ocorreram a partir das mudanças econômicas ocorridas neste período.

Os jornais populares procuram estreitar a relação com o leitor, utilizando diversos recursos como o foco na prestação de serviços, no entretenimento e nos temas ligados ao cotidiano das pessoas comuns.

Ao pesquisarmos a lexia "popular" no Dicionário Houaiss, o adjetivo pode ser definido como: "1. Relativo ou pertencente ao povo, esp. à gente comum; 2. Feito pelas pessoas simples, sem muita instrução; 3. Dirigido às massas consumidoras; 4. Ao alcance dos não ricos, barato" ${ }^{1}$. Já a lexia "sensacionalismo" aparece como "1. Gosto ou busca pelo sensacional; 2. Uso e

\footnotetext{
${ }^{1}$ Em: <http://200.241.192.6/cgi-bin/houaissnetb.dll/frame>. Acesso em: 20 de junho de 2013.
} 
efeito de assuntos sensacionais, capazes de causar impacto, de chocar a opinião pública, sem que haja qualquer preocupação com a veracidade"”2.

Assim, entendemos que o jornalismo do qual tratamos constituiria aquele relacionado ao cotidiano popular, ao banal e que tenha como característica o apelo à emoção e/ou ao escândalo. Porém, o sensacionalismo pode ser encontrado não somente em jornais populares, mas, também, em jornais tradicionais. Por isso, o termo sensacionalista já não pode esclarecer ou resumir as estratégias discursivas dos jornais populares, pois os mesmos vêm sendo reformulados.

A concepção de popular trabalhada aqui é baseada na ideia de Amaral (2006) a respeito de uma imprensa autointitulada popular e é bem consumida pelo seu público-alvo. Ela é composta de jornais baratos, com baixa paginação, vendidos em bancas, sem serviço de assinante, e que incorporam publicidades de produtos para a baixa renda. Além disso, é um tipo de imprensa que tem proximidade e empatia com o seu público, principalmente porque utiliza elementos culturais historicamente relacionados com as classes populares ou produzidos por eles.

Não há um consenso em relação à data de surgimento do jornalismo popular, uma vez que muitos dos primeiros jornais de cada país traziam características de uma linguagem popular. Também não é possível desassociar jornalismo sensacional de jornalismo popular, pois esse rótulo era utilizado para designar os jornais voltados para o público de baixa renda, designando o grau mais elevado de mercantilização da informação. Hoje em dia, essa noção

\footnotetext{
${ }^{2}$ Em: <http://200.241.192.6/cgi-bin/houaissnetb.dll/frame>. Acesso em: 20 de junho de 2013.
} 
está ultrapassada, porque os diversos segmentos populares são baseados em características diversas que não devem ser avaliadas de maneira generalista.

$\mathrm{Na}$ França, por exemplo, desde a metade do século XVI, havia os periódicos Gazette de France e Nouvelles Ordinaires voltados para as classes C,D,E e que se assemelhavam aos jornais sensacionalistas de hoje em dia, trazendo informações fantásticas que agradavam a todos (Amaral, 2006). Nos séculos XIX e XX, na Europa e América do Norte, os jornais que mais prosperaram foram os populares, que eram direcionados à maioria da população, recém-alfabetizada.

Um público que ansiava por parágrafos curtos, manchetes grandes e diversão junto com a informação. Alguns editores se deram conta do potencial desse mercado e reduziram o preço do exemplar, atraindo um grande número de leitores e obtendo lucro significativo. (Gontijo, 2004, p.224)

A imprensa popular nos EUA se destacou com o surgimento dos concorrentes New York World, de Joseph Pulitzer, e do New York Morning Journal, de William Randolph Hearst. Os dois jornais se especializaram em publicar histórias de dramas pessoais, além de adotar estratégias publicitárias para aumentar a vendagem, premiando os leitores com brindes, inventando notícias e entrevistas afim de entreter o seu público. A expressão "imprensa amarela", segundo Amaral (2006), surgiu em virtude do sensacionalismo dos dois jornais. Era uma referência ao personagem de uma história em quadrinhos, Yellow Kid, publicado no New York World. Tal expressão passou a ser usada para representar esse tipo de jornal sensacionalista. No Brasil, foi substituída por "imprensa marrom". 
Há quem diga que a expressão "jornalismo marrom" veio da referência à expressão francesa impremeur marron pela qual se conheciam os impressores ilegais do século XIX na Europa. Já o jornalista Alberto Dines afirmou em entrevistas que a expressão ficou generalizada a partir do uso no jornal Diário da Noite (RJ) em 1960. Dines, repórter do jornal na época, soube que alguém havia se matado por ter sido chantageado por uma revista de escândalos e fez uma manchete mencionando que a imprensa amarela havia levado um cineasta ao suicídio. Calazans Fernandes, chefe de reportagem, teria alterado a manchete: trocou a expressão "imprensa amarela" por "imprensa marrom", relacionando o marrom a "cor de merda". Desde então, a expressão jornalismo marrom é usada no Brasil para designar jornais e revistas de escândalos. (Amaral, 2006, p.19)

Em 1840, começaram a aparecer no Brasil os primeiros elementos de sensacionalismo introduzidos na imprensa a partir dos folhetins, mas foi a partir de 1920 que surgiram os primeiros jornais voltados para o segmento popular. Desses jornais, os mais importantes foram Folha da Noite (São Paulo, 19211960), O Dia (Rio de Janeiro, 1951 até os dias de hoje), Última Hora (Rio de Janeiro, 1951-1964), Luta Democrática (Rio de Janeiro, 1954-1979) e Notícias Populares (São Paulo, 1963-2000). Cada periódico agiu de forma diferente. Os jornais abordavam temáticas políticas e faziam reivindicações populares, servindo como intermediário entre o povo e o governo. Eles utilizavam recursos sensacionalistas para se tornarem mais próximos das classes populares, além de incorporarem seus elementos culturais.

Os jornais Última Hora e Notícias Populares, por exemplo, defendiam a posição política do seu dono. O primeiro era a favor de Getúlio Vargas; o 
segundo foi criado por líderes da União Democrática nacional (UDN). O Notícias Populares possuía as mesmas características do Última Hora, abordando temáticas que envolviam sexo, crime e sindicato, com exceção da política tradicional. De acordo com Amaral (2006), a proposta inicial do jornal era de ser anticomunista e tirar as massas do caminho da política. Já o Última Hora era um jornal populista, tribuna de Getúlio Vargas, cuja definição era "do povo para o governo".

Lage (2001) afirma que a grande imprensa brasileira é de elite e, por isso, muitos dos jornais populares existentes no começo do século praticamente sumiram desde a extinção dos subsídios ao papel, no início da década de 60. A leitura de jornais, no Brasil, passou a ser considerada por muitos um diferencial de classe, uma ocupação própria dos formadores de opinião. Os jornais já não eram feitos para todos, mas para camadas do público.

Nos anos 90, o Brasil passou a rever seus objetivos nacionais em virtude de uma nova política mundial. Muitos jornais voltados para as classes populares e com um formato parecido surgiram após 1997: Extra (RJ), Agora São Paulo (SP), Folha de Pernambuco (PE), Primeira Hora (MS), Notícia Agora (ES), Expresso Popular (SP), Diário Gaúcho (RS), Super Notícia (BH) e Aqui! (BH), do grupo Diários Associados, que, nos últimos anos, vem expandido a marca para outros estados, incluindo o Aqui PE, objeto deste estudo.

Por fazerem parte de uma vertente jornalística que valoriza a linguagem popular das notícias, o conteúdo do noticiário popular detém-se na dramatização ou humanização dos acontecimentos, enfocando principalmente os conflitos pessoais que fornecem aos leitores "elementos para projeção ou 
identificação, a partir dos seus problemas pessoais, o que permite a consumação de experiências catárticas" (Melo, 2003, p.189). Sendo assim, essas mensagens precisam estar ajustadas ao público-alvo, permitindo que se haja uma identificação com os termos usados.

Os jornais populares, segundo Amaral (2006), fazem parte de um novo mercado voltado para as classes C, D e E. É um segmento jornalístico mais focado no entretenimento e na prestação de serviços. O cotidiano das pessoas se torna a pauta principal, prevalecendo o interesse do público sobre 0 interesse público. A fim de se aproximar mais das camadas populares, esses impressos apresentam uma entonação diferente do jornalismo tradicional. Essa característica varia de periódico para periódico, mas os incluem num mesmo segmento.

Transformações de atitude linguística, isto é, de alteração do prestígio social das formas orais, vêm ocorrendo no dia-a-dia da linguagem urbana. Vocábulos e estruturas linguísticas ligados às classes populares se incorporaram ao uso, introduziram-se na mídia, participando de veículos de comunicação, como o rádio, a TV e a imprensa. (Dias, 1996, p.17)

Os meios de comunicação estão interessados em atingir essa parte da população, utilizando a variação linguística popular como estratégia de mercado, já que o público pouco escolarizado também consome jornais. Por causa disso, a linguagem precisa ser ajustada, a fim de atingir seus objetivos. Além disso, a ideia do jornalismo popular é não concorrer com os grandes jornais, que têm um formato tradicional.

Amaral (2006) observa que dentre as características padrões de um jornal popular está o fato de que eles são vendidos somente em bancas de 
jornais e suas capas são sempre chamativas, enfocando, com certa frequência assuntos que envolvem violência, mas com imagens cada vez mais raras de cadáveres. Além disso, esses periódicos buscam uma linguagem mais simples, o didatismo, a prestação de serviços e também a credibilidade. Eles abrangem as regiões metropolitanas e dão enfoque à editoria de Cidades. A temática política, atualmente, vem ocupando um lugar mais expressivo nesses jornais.

Verificamos, por meio dessa descrição da autora, que o jornal popular segue uma estrutura que se diferencia do padrão sensacionalista, mas também não se enquadra num perfil tradicional de jornalismo. Sua principal característica, a linguagem objetiva, mantém o vínculo com uma proposta original do jornalismo: clareza da informação. Segundo Pena (2008, p. 82), "o jornalista procura diminuir ao máximo o grau de entropia, pois sabe que seu público é heterogêneo e precisa de um entendimento imediato".

Apesar de todas as diversidades conceituais e estruturais do jornalismo popular, Dias (1996) destaca que boa parte das notícias são redigidas dentro das normas sintáticas cultas e que a variação popular recai mais sobre 0 vocabulário, que é a parte da língua mais sujeita a renovações. Exemplos disso são as gírias e expressões populares, que aparecem com mais frequência na linguagem das manchetes que na das notícias. Isso demonstra a preocupação do jornal com a sua vendagem, pois quanto mais chamativos forem os conteúdos das manchetes, mais interesse o jornal desperta no seu público. Através da utilização de gírias e expressões populares, o jornal popular demonstra estar sempre atualizado.

Para Gurgel (1990), a gíria contribui com o maior número de palavras e blocos, frases, expressões ou alocuções para a linguagem usual e 0 
equipamento falado. Ouro fator importante a ser ressaltado é que as gírias estão relacionadas com a época e o módulo de situação. Cada época tem sua gíria e, por isso, muitas delas surgem, têm a sua expectativa de vida, desempenham o seu ciclo e finalmente desaparecem.

No entanto, apesar de muitas das gírias serem um produto da época, algo relacionado à moda, muitas delas resistem por tempo maior. Algumas são absorvidas pela própria língua e passam a fazer parte do seu patrimônio, incorporando-se à linguagem padrão.

Segundo Amaral (2006), os periódicos populares buscam falar do universo de seus leitores, utilizando recursos temáticos, estéticos e estilísticos diferenciados do discurso jornalístico tradicional. Eles valorizam o cotidiano e a percepção de mundo personalizada, dando um enfoque subjetivo e pessoal às notícias.

Dias (1996, p.63) confirma que o envolvimento do redator muitas vezes estabelece um efeito narrativo muito a gosto da conversação, "criando-se um estilo de narrar que se aproxima da oralidade e que nos surpreende nos momentos menos esperados". Ainda segundo a autora, o jornalismo popular busca atender a uma expectativa do leitor, assim como no discurso oral, cujo falante tem interesse em satisfazer às expectativas do seu interlocutor.

A compreensão do que é o jornalismo popular tem ligação com os primórdios dos jornais populares dos anos 1970 e 1980, sendo passíveis de comparação, em determinados aspectos, com o estilo sem pudores e ficcional do Notícias Populares (NP), ícone do início desse tipo de publicação no Brasil. O aspecto que ainda pode ser identificado nos jornais populares é trinômio escândalo-sexo-sangue, que celebrizou o NP. 


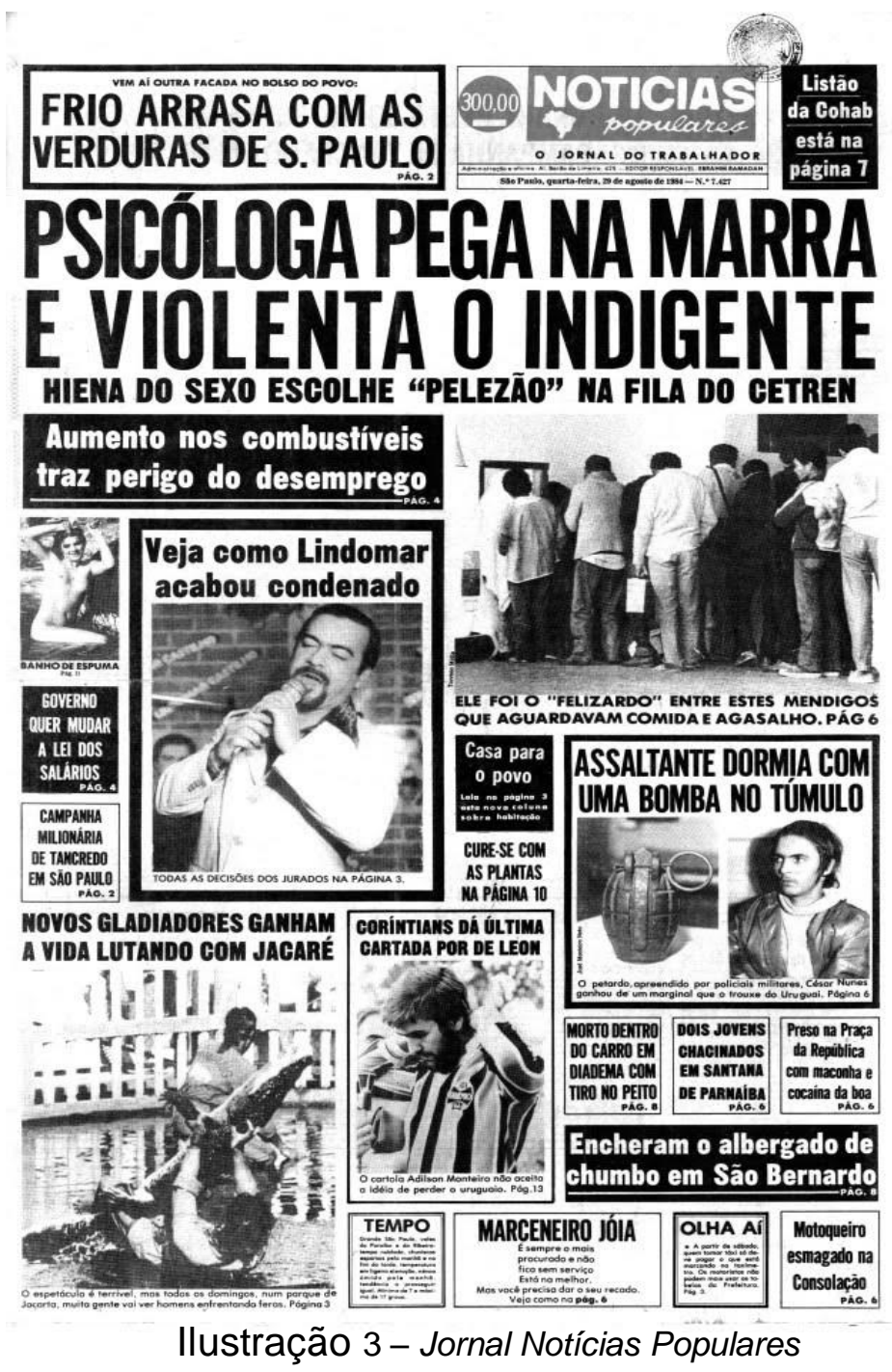

O Instituto Nacional de Jornais $(\mathrm{ANJ})^{3}$ aponta que cinco entre os dez jornais de maior vendagem do país em 2012 se encaixam no perfil de jornal popular. Estão nesse bloco o Super Notícia, de Minas Gerais, o Extra e o Meia Hora de Notícias, do Rio de Janeiro, o Diário Gaúcho, do Rio Grande do Sul, e o Daqui de Goiás.

Os jornais populares são comercializados em bancas ou em lugares de grande circulação, como estações de trem e metrô, devido ao poder aquisitivo dos leitores das classes para as quais são destinados. A circulação dos jornais

\footnotetext{
${ }^{3} \mathrm{Em}:<$ http://www.anj.org.br/a-industria-jornalistica/jornais-no-brasil/maiores-jornais-do-brasil>. Acesso em: 21 de junho de 2013.
} 
populares deve-se as estratégias de marketing como a distribuição de brindes ou o foco em notícias sobre celebridades ou entretenimento.

Tal escolha das notícias de um jornal popular, ou mesmo em jornais de referência, são analisadas e julgadas pelo jornalista, pois todo acontecimento deve ter determinadas qualidades, conhecidas como valores-notícias (Wolf, 1995). Os valores-notícia não são precisos, alteram e misturam-se permanentemente. Os jornais populares, assim como os de referência ${ }^{4}$, empregam diversas estratégias parecidas para seduzir seus leitores. Contudo, ao considerarmos o segmento popular detalhadamente, notaremos que alguns valores-notícia são predominantes.

Os temas noticiados pelos jornais populares diferem dos jornais de referência porque o lugar econômico, social e cultural do leitor é diferente do lugar do leitor dos jornais de referência. O leitor das classes C e D vive com renda menor, tem baixa escolaridade e depende dos poderes públicos para poder ter acesso à educação e saúde e não tem acesso a entretenimento. Assim, as notícias dos jornais populares têm relação com o cotidiano do leitor e tendem a mostrar a notícia do ponto de vista do leitor.

O aparecimento dos jornais populares pode ser entendido a partir do contexto sociocultural referente ao aparecimento de um novo sujeito, dentro de uma sociedade em que há um excesso de informação midiatizada e cuja população procura por informação. Destacamos que os jornais populares são orientados por uma visão prévia do público a que se destina, e tal visão prévia orienta o Lugar de Fala do jornal. Tal estratégia conseguem aproximar, assim,

\footnotetext{
${ }^{4}$ Os jornais de referência são conhecidos como quality papers e considerados veículos de credibilidade entre os formadores de opinião.
} 
mais o jornal dos seus leitores, pois deixa aparente a eles sua vivências cotidianas e abordam assuntos que afetam diretamente seu público-leitor.

Podemos perceber, também, que nos jornais populares há uma tendência de banalização das notícias, de acordo com Sodré (2002).

Os meios de comunicação de massa tornam-se a hipóstase de um modelo macroscópico de implosão das mediações tradicionais (representacionais ou expressivas), que podem ser entendidas como as 'mensagens', a 'realidade' e a própria ideia de 'meio'. A informação colocada na esfera pública da comunicação, por um gigantesco processo tecnológico e industrial, absorve e neutraliza conteúdos, dissolvendo a sociabilidade tradicional. (Sodré, 2002, p.30)

Com base na citação do autor, podemos afirmar que o conteúdo noticiado pelos jornais muitas vezes é banalizado perante a importância do ato de comunicar e noticiar algo. Por isso, os novos jornais populares poderiam ser percebidos como uma decorrência desse fenômeno.

O fenômeno dos jornais populares deve-se à necessidade de uma nova forma de comunicação para que as classes sociais menos favorecidas e com menos acesso à informação pudessem ser incluídas no processo informativo, o que torna a mídia um lugar de produção social de sentido. Porém, os jornais populares tendem, muitas vezes, ao uso de estratégias como o caricato para causar humor e atrair o leitor.

O caricato seriam as situações colocadas como ridículas e que produzem o riso no leitor, ainda que a situação noticiada derive de algo sério. Ao causar o riso, rompe-se com a tradição e traz-se para o leitor um novo 
aspecto, distinguida pelo fato. Utilizando-se do caricato, os jornais populares dialogam com seu público por meio do jornalismo e do humor.

Das páginas sensacionalistas dos jornais às revistas de fofocas com celebridades e à heterogeneidade da programação televisiva, a massa busca um espetáculo que a divirta e ao mesmo tempo a integre, ainda que imaginariamente no espaço público - espaço, como se sabe, historicamente difícil de se constituir num país como o Brasil, cujas elites sempre sufocaram o Estado e a república com seus interesses privados (Sodre e Paiva, 2002, p.110).

A escolha dos temas a serem noticiados também é importante estratégia dos jornais populares, estes trabalham com a quebra de padrões presentes no jornalismo de referência, e o ponto chave dessa estratégia é a transformação das notícias em "espetáculo". As manchetes são chamativas, bizarras e humoristícas; são utilizadas letras grandes e coloridas; e as escolhas das imagens revezam-se entre futebol, violência e mulheres seminuas. Os jornais populares, além da aproximação com o leitor, anseiam trabalhar com o lado emocional do leitor, a fim de fazê-lo ter prazer em ler o jornal. Entretanto, tais estratégias podem interferir na finalidade principal da imprensa, alcançar o interesse público e não apenas o do leitor.

Os jornais populares apresentam, conforme classificado por Duarte et al (2008), uma tríade temática, que seria composta pela veiculação de notícias relacionadas a: erotismo, violência e futebol. Mas, para que não haja dificuldade na codificação da mensagem, esses jornais constituem um equilíbrio na estrutura das capas; a cada capa, somente um dos elementos da 
tríade está em destaque. Percebe-se também a utilização do dueto realidade/ficção, na utilização de fotomontagens e seguindo os interesses mercadológicos do jornal, sem perder de vista a interação com os leitores.

Por fim, quando falamos em jornal popular e sensacionalismo precisamos levar em conta que a prática do sensacionalismo está inserida tanto no circuito do capital, quanto no da produção e o da circulação simbólica. Para Amaral (2006), o sensacionalismo pode utilizar, por vezes, artifícios inadmissíveis para a ética jornalística, porém pode ser somente uma estratégia de se comunicar de modo mais eficaz com os seus leitores, a partir de uma matriz cultural e estética distinta da que é empregada pela imprensa de referência. Assim, a distinção entre os jornais populares e os de referência não pode se dar somente com base em estratégias sensacionalistas.

A concepção de popular trabalhada aqui é baseada na ideia de Amaral (2006) a respeito de uma imprensa autointitulada popular e é bem consumida pelo seu público-alvo. Ela é composta de jornais baratos, com baixa paginação, vendidos em bancas, sem serviço de assinante, e que incorporam publicidades de produtos para a baixa renda. Além disso, é um tipo de imprensa que tem proximidade e empatia com o seu público, principalmente porque utiliza elementos culturais historicamente relacionados com as classes populares ou produzidos por eles.

Não há um consenso em relação à data de surgimento do jornalismo popular, uma vez que muitos dos primeiros jornais de cada país traziam características de uma linguagem popular. Também não é possível desassociar jornalismo sensacional de jornalismo popular, pois esse rótulo era utilizado para designar os jornais voltados para o público de baixa renda, designando o 
grau mais elevado de mercantilização da informação. Hoje em dia, essa noção está ultrapassada, porque os diversos segmentos populares são baseados em características diversas que não devem ser avaliadas de maneira generalista.

\subsection{A linguagem jornalística}

A linguagem utilizada pelos jornais enfatiza o conteúdo informativo a ser transmitido. Informação que será difundida em grande escala e para um público diverso. Pensando em tais questões, há uma necessidade de se adaptar as variáveis formais, reduzindo-as, para que haja uma apreensão eficaz. Assim, o texto jornalístico, segundo Lage (2001b, p.35), precisa ser submetido constantemente à crítica, "que remove o entulho e repõe vida nas palavras".

O texto jornalístico contém informação conceitual e procura suprimir usos linguísticos que se caracterizam pobres de valores referenciais, como as fórmulas congeladas das cartas comerciais e requerimentos, que não dão conta da variedade de situações próprias do mundo objetivo, tendendo a se diferenciar da língua corrente.

Lage (2001b) relaciona algumas restrições da linguagem jornalística às seguintes ocorrências: os registros de linguagem, o processo de comunicação e os compromissos ideológicos. Em relação aos registros de linguagem, o autor compartilha a mesma ideia sobre os estudos a respeito da heterogeneidade da língua, uma vez que nela estão contidos os usos regionais, os discursos especializados e os dois registros de linguagem citados no capítulo anterior: o formal (mais próximo da modalidade escrita e das situações 
tensas) e o coloquial (que compreende as expressões correntes na modalidade falada).

Quando se há uma conciliação entre o interesse de uma comunicação eficiente e ao mesmo tempo de aceitação social, temos uma linguagem jornalística constituída de palavras e expressões possíveis tanto no registro coloquial quanto no registro formal. Isso se aplica a qualquer época ou região, adaptando-se a linguagem às alterações próprias da língua.

Lage (2001b, p.38) abaixo discorre a respeito dessa linguagem incorporada pelo jornalismo e que faz uso dos registros formais associados aos interesses da comunicação. Na coluna do centro, encontram-se as formas usualmente preferíveis.

A linguagem jornalística tem, hoje, as seguintes características, segundo Lage (2001b, p.38):

\section{A - quanto à escolha de itens lexicais}

1. Utilização, sempre que possível de palavras admissíveis no registro formal e no registro coloquial da linguagem, isto é, daquelas palavras que pertencem, ao mesmo tempo, ao conjunto dos itens léxicos aceitos na linguagem formal e na linguagem coloquial. Sempre que os sentidos sejam permutáveis, entre perfunctório e superficial, o preferível, portanto, é superficial; entre próximo a e perto de, é perto de; entre recinto e sala, é sala; entre pretérito e passado, é passado; entre sintagma e locução, é locução. A regra se aplica, no geral, tanto ao texto escrito quanto ao coloquial simulado.

2. Criação de neologismos e atualizações necessárias (malufista, petista), formas condensadas que se originam da circunstância de os títulos terem letras contadas (FHC por Fernando Henrique Cardoso, desarme por 
desarmamento), bem como a incorporação de expressões populares e de gíria que se generalizam (bumbum, cheque voador).

3. Eliminação, sempre que possível, de preciosismos, palavras estrangeiras, de gíria local e jargão profissional. Palavras técnicas, quando necessárias - e elas se tornam necessárias em períodos de intensa transformação tecnológica como o atual - devem ser usadas com parcimônia (na linguagem jornalística, seria preferível com moderação) e definidas pragmaticamente, isto é, com a explicação necessária apenas a seu entendimento imediato.

Assim, por exemplo, na descrição de uma cirurgia: o corte é feito na artéria femural, a principal da coxa, quatro dedos acima do joelho... e não: $O$ corte é feito, seis centímetros acima da borda da rótula, na artéria femural, ramo primário da aorta descendente que se nomeia como artéria ilíaca até o ponto em que, ao sair da região ínguino-crural, assume esse nome ...

1. a teoria geral por detrás dessas escolhas é de que a precisão é sempre relativa, dependendo do contexto da enunciação. Se um político sofre de câncer, isto basta numa notícia destinada ao público em geral, mas não bastará certamente a seu médico assistente, que precisará averiguar a natureza, tamanho e localização do tumor, no mínimo. A informação de que uma nave experimental é movida a jatos de partículas subatômicas ou íons é adequada e bastante para um público com formação básica escolar completa, mas nitidamente insuficiente para um físico, que gostaria de dispor de detalhes sobre o funcionamento desse motor iônico; a mesma informação é, por outro lado, inacessível a pessoas sem formação básica completa ou que não prestaram a atenção merecida às aulas de ciências - daí o bom senso de se 
acrescentar no jornal uma explicação suplementar tal como "este é um tipo de motor que só existia em filmes de ficção e histórias em quadrinhos".

2. eliminação (com exceção das citações), de adjetivos e categorias testemunhais, isto é, daqueles e daquelas cuja aplicação depende da subjetividade de quem produz a mensagem. Assim, evita-se dizer que alguém é rico, ou que é bonito, ou que é notável; prefere-se alinhar os bens, reproduzir depoimentos de entendidos sobre a beleza ou contar episódios em que se comprova a notabilidade. A preferência pela adjetivação fatual ou comprovável (números, evidências) atende à circunstância de o jornalismo ser um discurso impessoal, da perspectiva do consumidor. Não conhecendo o autor do enunciado, ele geralmente não é capaz de avaliar os padrões de referência da aferição: em relação a que média se é rico, a que padrão étnico ou estético se reporta a beleza, qual a natureza ou intensidade da notabilidade atribuída.

3. eliminação, na medida do possível e com exceção de citações, de advérbios que expressam juízos de valor ou modulam predicações e sentenças, situando-as em mundos possíveis ou desejáveis - em suma dos advérbios de modo, intensidade e afirmação. Essa característica é importante para uma descrição formal, porque esses advérbios oferecem dificuldades suplementares para a análise, por serem elementos lógicos de segunda ordem, ou seja, que predicam o que já está predicado, atuando como funções de funções. O jornalismo reporta-se ao mundo real (é fundamento filosófico do ofício que ele existe), não ao que ao mundo que seria possivelmente, provavelmente, supostamente, desejavelmente, preferivelmente etc.

4. na mesma linha, restrição genérica e entendimento particular de verbos de atitude proposicional, isto é, que expressam esperanças, temores, 
desejos etc. quanto à proposição que os sucede, precedida de que (o que em inglês se chama de that verbs).

É o caso de considerar, esperar, ameaçar, parecer etc. - verbos cujo sentido pleno reporta-se à pessoa do falante. Quando se lê em um veículo de informação que "X considera que P", é tácita a leitura "X disse que considera que P".

\section{B - quanto aos procedimentos gramaticais}

1. de maneira paralela ao que ocorre quanto aos itens léxicos, utilizamse as formas sancionadas no registro formal e aceitas no registro coloquial da linguagem.

Construções em desuso, como as mesóclises, são definitivamente suprimidas; há forte tendência em favor da próclise em lugar da ênclise, por ser este o uso coloquial corrente no Brasil; pela mesma razão, é mais comum a forma analítica do que asintética do pretérito mais que perfeito, etc.

2. de modo geral, os jornalistas estão comprometidos com a normalização da língua, embora priorizem a necessidade de informar; assim, o verbo assistir, quando tem regência indireta (assistir ao espetáculo), não deveria admitir voz passiva (o espetáculo foi assistido por...), que, no entanto, tornou-se usual pela inexistência de qualquer outro verbo que permitisse apassivar a construção (o espetáculo foi presenciado por... não é o mesmo que o espetáculo foi assistido por...).

3. a linguagem do jornalismo é mais dinâmica do que a linguagem formal. Reflete, apesar da preocupação com a norma, os usos que se tornam correntes na língua coloquial, como, por exemplo, a tendência de violar a concordância verbo-nominal quando verbos pronominais vêm antes dos 
elementos descritos tradicionalmente como sujeitos: Vende-se casas, ampliase as possibilidades...

4. Os períodos costumam ser mais curtos do que no uso formal. Períodos muito longos (com mais de 20 palavras, em média, dependendo, naturalmente, do grau de coesão) são de leitura difícil e seletiva quanto ao nível cultural do leitor. A brevidade é evidentemente maior nos enunciados destinados a serem lidos, no rádio ou televisão, e nos que se destinam à veiculação noticiosa pela Internet.

5. As sentenças são construídas, quase sempre, na terceira pessoa, com exceção das citações em discurso direto. Os tempos preferenciais, nas notícias, são o passado perfeito, o futuro e o presente pelo futuro, reservandose o presente concomitante ou frequentativo para as interpretações e as formas imperfeitas para descrições que caracterizam os agentes - personagens e entidades em geral que interferem no enunciado. O subjuntivo é de uso restrito e há nítida preferência pelo infinitivo impessoal.

Em suma: o texto jornalístico utiliza um léxico simplificado, sistema verbal restrito à terceira pessoa e a alguns tempos verbais, constrói períodos mais curtos e evita ou delimita o sentido de construções problemáticas, como as proposicionais. Isso the permite produção rápida e eficiente para fins informativos, obedecendo às normas gerais da língua. No entanto, confina a abrangência dos enunciados: a informação em jornalismo é axiomática, geralmente não dedutiva, dispensa a argumentação e as estratégias de convencimento.

Em resumo: no jornalismo, enfatiza-se o conteúdo da informação, que será processada em escala industrial, para consumo imediato. Por causa disso, 
há uma necessidade de se adequar às variáveis formais, reduzindo-as, para que haja uma compreensão eficaz. De acordo com Lage (2001b, p.35), o texto jornalístico precisa ser submetido constantemente à crítica, "que remove o entulho e repõe vida nas palavras".

O texto jornalístico contém informação conceitual e procura suprimir usos linguísticos que se caracterizam pobres de valores referenciais, como as fórmulas congeladas das cartas comerciais e requerimentos, que não dão conta da variedade de situações próprias do mundo objetivo, tendendo a se diferenciar da língua corrente.

Lage (2001b) relaciona algumas restrições da linguagem jornalística às seguintes ocorrências: os registros de linguagem, o processo de comunicação e os compromissos ideológicos. Em relação aos registros de linguagem, o autor compartilha a mesma ideia sobre os estudos a respeito da heterogeneidade da língua, uma vez que nela estão contidos os usos regionais, os discursos especializados e os dois registros de linguagem citados no capítulo anterior: o formal (mais próximo da modalidade escrita e das situações tensas) e o coloquial (que compreende as expressões correntes na modalidade falada).

Quando se há uma conciliação entre o interesse de uma comunicação eficiente e ao mesmo tempo de aceitação social, temos uma linguagem jornalística constituída de palavras e expressões possíveis tanto no registro coloquial quanto no registro formal. Isso se aplica a qualquer época ou região, adaptando-se a linguagem às alterações próprias da língua.

Lage (2001b, p.38) estabelece o quadro abaixo a respeito dessa linguagem incorporada pelo jornalismo e que faz uso dos registros formais 
associados aos interesses da comunicação. Na coluna do centro, encontramse as formas usualmente preferíveis.

\subsection{A estrutura do jornal}

Segundo Marcuschi (2008, p.174), suporte de um gênero é um locus físico ou virtual com formato específico que serve para suportar, fixar e mostrar um gênero materializado como texto. O jornal é considerado um suporte textual à medida que agrupa uma série de gêneros textuais, como notícias, artigos, chamadas, notas, crônicas, charges etc, em uma estrutura composta por editorias, que são seções com assuntos variados (Esportes, Cultura, Política, entre outros). Cada um desses gêneros possui características particulares, tanto em relação à linguagem, quanto à estrutura. Abaixo, algumas definições de acordo com o Manual da Redação da Folha de S. Paulo (2010):

Primeira Página - mostra os principais assuntos da edição e deve ser representativa de todas as editorias. O texto deve ser claro e conciso. Há sempre a presença de fotos e artes (em cores). É importante salientar que a primeira página de um jornal é feita por uma equipe exclusiva. Seu conteúdo é definido em reuniões vespertinas diárias.

Chamada - é um texto curto na Primeira Página, resumindo as informações publicadas pelo jornal a respeito de determinado assunto. Remete o leitor às páginas que trazem a cobertura extensiva. 
Manchete - é a principal notícia do dia, portanto, deve receber o título mais importante da Primeira Página.

Chapéu - é uma palavra ou expressão curta que vem acima de um título. É utilizada para indicar o assunto de que trata o texto ou os textos que seguem abaixo dela.

Título - grande parte dos leitores de um jornal lê apenas o título da maioria dos textos. Daí a importância do título: ou é tudo que o leitor vai ler sobre o assunto ou é o fator que vai motivá-lo, ou não, a ler a notícia completa. O título se configura como uma síntese precisa do fato mais importante do texto. Deve trazer sempre 0 aspecto mais específico do assunto.

Linha fina - é uma frase ou um período sem ponto final que aparece abaixo do título, completando seu sentindo ou acrescentando informações extras. A linha fina funciona como subtítulo. As letras utilizadas são menores que as do título e maiores que as do texto.

Lide (ou lead) - é o primeiro parágrafo do texto, cuja função é introduzir o leitor no texto e prender sua atenção. Há dois tipos de lide: o noticioso, que procura responder às questões sobre um fato (o quê, quem, quando, como, onde por quê?),e o não-factual, que explora outros recursos para chamar atenção do leitor. 
Olho - é um recurso de edição utilizado para destacar os melhores trechos de textos longos. Normalmente tem apenas três linhas de texto centralizadas, nas quais aparecem destacadas frases relevantes e sugestivas do artigo, entrevista ou transcrição.

Intertítulo - é um pequeno título que aparece no interior dos textos muito longos, com função de arejar a leitura.

Notícia - é o registro dos fatos, sem opinião. A exatidão é a característica principal da notícia; no entanto, vários fatos podem ser justapostos de maneira tendenciosa. Suprimir ou inserir uma informação no texto pode alterar o significado da notícia.

Essas nomenclaturas são importantes para que se compreenda como funciona a estrutura do jornal e a importância de cada gênero no processo de comunicação. Algumas dessas estruturas podem não aparecer em alguns jornais com certa frequência - é o caso do olho e do intertítulo. Outras recebem nomes diferentes, como é caso da linha fina, conhecida também como subtítulo ou sutiã. 


\section{CAPÍTULO 3 - A QUESTÃO DO GÊNERO}

A todo instante produzimos e interpretamos diversos tipos de texto em nossas interações diárias. Tais textos diferenciados por diversos estilos, propósitos, modos de organização, conteúdo e formatos. No entanto, não concretizamos nossa troca comunicativa de forma ocasional. Seguimos, basicamente, um cabedal de formas ritualizadas, porém, ao mesmo tempo, com certo grau de dinamicidade, construídas sócio-historicamente, conhecidas como gêneros textuais.

\subsection{Gêneros primários e secundários}

Bakhtin (2000, p.280) afirma que houve a preocupação de se estudarem os "gêneros do discurso cotidiano", de modo particular, o da réplica do diálogo cotidiano. Ele rememora todo o curso por que passou o estudo dos gêneros, começando pelos "gêneros literários" (voltados para os aspectos artísticoliterários e despreocupados com a linguagem), passando pelos "gêneros retóricos" - com pouca diferença dos mencionados anteriormente, porém mais atentos à linguagem oral - e desembocando nos "gêneros do discurso cotidiano" - com mais atenção ao componente linguístico.

Para Bakhtin, é indispensável avaliar a heterogeneidade dos gêneros do discurso e os problemas em definir a natureza genérica do enunciado. Segundo ele, os gêneros se dividem em primários (considerados simples, e nesse grupo se insere a réplica do diálogo cotidiano, a carta) e secundários (considerados complexos, como o romance, o teatro, o discurso científico, ideológico, etc.) e aqueles que concentram e transmutam estes. Nesse caso - 
aqui se instala a crítica de Bakhtin - quando uma carta (gênero simples), por exemplo, é assimilada por romance (gênero complexo), apesar de seu conteúdo e significado retratem a realidade cotidiana, não é parte da realidade exterior/cotidiana, mas sim parte da vida literário-artística.

Deste modo, a "saída" encontrada por Bakhtin (2000, p.282) foi remir a relação entre os gêneros primários e secundários e o processo histórico da composição dos gêneros secundários no estudo dos gêneros, e não somente como faziam os behavioristas, analisar o fenômeno dos gêneros sob o ângulo exclusivo dos gêneros primários. Assim, é possível explicar a crise pela qual passaram as bases oferecidas por Aristóteles, com o surgimento do Romantismo, e o porquê de as teorias mais modernas considerarem o gênero como uma categoria fluida (Marcuschi, 2006, p.23), ou seja, de natureza híbrida.

\subsection{Elementos do gênero}

Sobre os elementos do gênero jornalístico o primeiro critério a ser adotado, segundo Melo (2003), é o da intencionalidade, com duas vertentes, a reprodução do real e a leitura do real. No primeiro caso, tem-se a observação da realidade e a descrição do que interessa à instituição jornalística. No segundo caso, tem-se a análise da realidade e a avaliação.

A necessidade que as pessoas têm de se informarem fez com que 0 jornalismo se articulasse em torno da informação e da opinião. Por isso o relato jornalístico assume duas modalidades: a descrição dos fatos e a versão dos 
fatos, necessitando estabelecer fronteiras entre a descrição e a avaliação do real. Resulta disso, então, o jornalismo informativo e o jornalismo opinativo.

O segundo critério adotado por Melo (2003, p.64) para esta classificação dos gêneros é a estrutura dos relatos notáveis nos processos jornalísticos, não como estrutura dos textos ou das imagens que representam e reproduzem a realidade, mas sim como "articulação que existe do ponto de vista processual entre os acontecimentos (real), sua expressão jornalística (relato) e a apreensão pela coletividade (leitura)".

Assim, o autor diferencia a natureza dos gêneros que se agrupam na categoria informativa dos que se agrupam na categoria opinativa. Nos gêneros que correspondem ao universo da informação, sua expressão não depende da instituição jornalística, mas sim da eclosão e evolução dos acontecimentos e da relação que há entre os profissionais/jornalistas com seus protagonistas.

Em termos de estudos linguísticos, ainda que haja uma certa recorrência a textos jornalísticos, existem poucos estudos destes gêneros.

De acordo com Bonini (1999), falta ainda uma explicação geral dos princípios de organização do jornal e de seus gêneros, ainda que muitos estudiosos da área jornalística já tenham elaborado algumas tipologias. Para o autor, ainda faltam, de forma sistemática, respostas a questões como o que é um gênero jornalístico e como este se constitui. Para tais respostas, o autor sugere que se tratem os gêneros jornalísticos a partir do processo de textualização do jornal.

Quanto às tipologias levantadas na literatura jornalística, Bonini (1999, p.36) delineia três linhas de conclusão para tal análise: 
I) a noção de gênero provém da teoria da informação;

II) a teoria de gênero tomada como base não possibilita 0 levantamento de critérios relativos aos gêneros propriamente, mas às funções do jornal; e

III) a inexistência de critérios mais refinados dificulta a visualização dos limites da categoria que se quer classificar.

Assim, Bonini (1999) traça uma resposta para a questão: o que seria o gênero em um jornal? Inicialmente, podemos dizer que se trata de um conjunto de parâmetros de textualização que, em função do hiper-gênero (o jornal), estruturam um propósito comunicativo(noticiar, opinar, criticar, localizar), linearizando uma unidade textual identificável como totalidade.

Os gêneros que fazem parte do jornal, de acordo com Bonini (1999), são aqueles que, em relativa estabilidade e autonomia, atendem aos propósitos comunicativos do jornal, ou seja, relatar fatos e informações recentes bem como interpretá-los, e desencadear processos opinativos e estar de acordo com a estruturação do jornal como gênero.

\subsubsection{O Gênero capa}

As capas de jornais mostram um número limitado de notícia, são mostradas aquelas que a equipe jornalística seleciona como principais. Além disso, dentre essas escolhidas, existe uma que tende a ter maior destaque, constituindo com isso, uma finalidade temática. Com isso, os editores constroem a composição da capa, organizando o texto verbal e visual de 
acordo com o que se quer chamar mais a atenção do leitor, e consequentemente, o estilo, sendo elaborado de acordo com os recursos lexicais disponíveis na notícia.

Segundo Travassos (2010), gênero capa de jornal funciona como um direcionador que facilita, orienta e seduz o leitor do jornal. Sua função, segundo a autora, é a de informar sobre o conteúdo veiculado no interior do periódico e de funcionar como um atrativo para a compra do jornal. Por trás do resultado atrativo que chega às bancas, a autora Luciana Moherdaui (2008) esclarece que há um planejamento editorial, o qual é responsável por definir as diretrizes, ideais, público alvo e, dessa forma, orientar a composição das páginas a partir de gêneros, noticiabilidade, entre outros critérios.

As capas de jornais, de acordo com Moherdaui (2008), possuem um equilíbrio de quatro elementos básicos: manchete, texto, foto e legenda. $E$ seguem sua composição com as características e possibilidades de cada meio. Eliseo Verón (2005) fomenta a explicação sobre a construção de uma capa ao indicar uma base de formulação:

(...) em uma mesma capa fala-se de vários temas diferentes, e cada tema se organiza em torno de um deslocamento entre dois níveis. Todo um sistema de marcas gráficas contribui para sublinhar a segregação entre as unidades de cada nível: a dimensão, a tipografia, a cor, a disposição na página. (Verón, 2005,p.208).

A capa de um jornal é similar à vitrine de uma loja, pois além da mera intenção de informar, serve para vender os jornais, seduzindo o leitor para que leia as notícias contidas em seu interior. 


\subsubsection{O Gênero Manchete}

Quando consideramos o discurso como uma unidade comunicativa, referimo-nos, basicamente, a um gênero de discurso verificado, que ditará as regras para a construção desse discurso, segundo o gênero no qual o mesmo esteja inserido. Portanto, o conceito de gênero discursivo de Bakhtin (2000) pode ajudar a melhor entendermos a estruturação e as características do gênero discursivo manchete, que será o gênero que servirá como objeto de análise para o presente trabalho.

Os gêneros de discurso, segundo Maingueneau (2004, p. 61), "são dispositivos de comunicação que só podem aparecer quando certas condições socio-históricas estão presentes." Assim, se um jornal cria manchetes é porque tal gênero possui uma função dentro da coletividade na qual está inserido e até mesmo dentro da mídia, pois o próprio jornal seria um macro-gênero discursivo multifacetado em outros (sub)gêneros, cada um marcando a sua função dentro do todo da linguagem jornalística. Diz-nos Dias (1996,p.106) que:

A manchete contém a macroinformação, cuja função é despertar o interesse do leitor para certos pontos que, espera-se, sejam desenvolvidos no corpo da notícia.

Há um encaminhamento da leitura, no sentido de que a ordem de relevância dada, muitas vezes, a um mero pormenor, sirva para atrair a atenção do leitor, conduzindo seu interesse, naquilo que $\circ$ jornal julga ser 0 mais importante e levando-o a uma leitura predeterminada.

Ao analisar o gênero notícia, Charaudeau (2006, p.132) considera que este constitui um "conjunto de informações que se relaciona a um mesmo 
espaço temático, tendo um caráter de novidade, proveniente de uma determinada fonte e podendo ser diversamente tratado."

O fato de o leitor (re)conhecer uma manchete se dá pelo que Maingueneau (2004, p. 63) chama de "economia cognitiva", que se refere ao fato de que a competência genérica (o domínio de diferentes gêneros) seria um componente facilitador da comunicação verbal. 


\section{CAPÍTULO 4 - CORPUS DA PESQUISA: JORNAL MEIA HORA DE NOTÍCIAS}

No quarto capítulo, apresentamos o corpus de nossa pesquisa, o jornal Meia Hora de Notícias, contextualizamos o jornal, o perfil do leitor e uma primeira tabulação sobre a temática das capas do jornal.

\subsection{Contextualizando o jornal Meia Hora de Notícias}

O Meia Hora de Notícias é um jornal do Rio de Janeiro e faz parte do grupo O Dia. Sua circulação iniciou-se em setembro de 2005. Trata-se de um tabloide popular, com o custo de $\mathrm{R} \$ 1,00$ (Um Real). Tem de 32 a 44 páginas, é matutino e tem como objetivo ser de fácil compreensão, utilizando linguagem acessível e coloquial. Inicialmente, apresentou-se como opção mais barata ao Jornal Extra, porém acabou atingindo outro nicho de público. Grande parte do noticiário é retirada do jornal O Dia. Os slogans do jornal são: "Nunca foi tão fácil ler jornal" e "Se tempo é dinheiro, Meia Hora é só R\$1,00". Informações obtidas no site da Associação Nacional de Jornais mostram uma média de 136.802 leitores diários, aproximadamente. Destes, segundo informações do site do departamento comercial do Grupo O Dia, $2 \%$ são da classe A, $24 \%$ da classe B, $60 \%$ da classe C, $13 \%$ da D e 1\% da E. O "Meia Hora de Notícias" alcança grande faixa da população devido à estratégia de colocar vendedores 
autônomos vendendo os jornais em locais estratégicos, como estações de metrô e ônibus, lugares frequentados diariamente pelo público-alvo consumidor do jornal. A tiragem média, nos dias de semana, é de 230 mil exemplares, número que lhe afere a posição de terceiro jornal mais lido do estado do Rio de Janeiro (perdendo para "O Globo" e "Extra") e sexto mais lido do Brasil.

As manchetes do Meia Hora de Notícias são permeadas por oralidade. Tais manchetes rompem com o ideal de neutralidade fazendo juízos e escolhas lexicais que provocam o humor. Além disso, não se valem da norma escrita culta como o padrão linguístico dos jornais. O Meia Hora, como já dito, é um produto destinado às classes populares. O estilo jornalístico popular busca retratar os acontecimentos cotidianos de forma cômica, empregando textos concisos, com um resumo dos acontecimentos, sem se aprofundar nos fatos. A escolha lexical é pela linguagem coloquial, sempre permeada por elementos da oralidade, tais como os neologismos e as gírias, linguagem escolhida para promover a aproximação com o linguajar do público-leitor.

O jornal faz a imagem de um leitor ideal menos intelectualizado, que prefira uma já opinião formada, cujos interesses se reduzam à violência, futebol e sexo. Soma-se a isso o fato de nem sempre dominarem a norma culta, como vemos, especialmente na primeira página, na qual não há um compromisso com a norma escrita ou seguimento de manuais de redação como nos demais jornais. O Meia Hora apresenta ao leitor uma leitura pronta, direcionada, monitorada, que não proporciona ao leitor refletir, questionar, nem o deixa livre para criar as suas próprias opiniões.

A temática das capas do Meia Hora é formada, basicamente, pela tríade: violência, futebol e sexo, estratégia comum no jornais populares. Essa tríade 
temática representa uma estratégia que compõe os quadros de sentido sobre determinado personagem, fato comum ou acontecimento jornalístico. O sexo ou erotismo, geralmente, é representado pela exibição de imagens de mulheres seminuas, explorando o corpo feminino.

O futebol é outro componente da tríade temática. O futebol e os jogadores-celebridades são representados nas capas do jornal, na maioria das vezes, estimulando a rivalidade entre os times locais. O destaque é dado inteiramente aos times do Rio de Janeiro, por se tratar de uma publicação carioca, cujo público-leitor é praticamente todo proveniente da cidade. O Meia Hora aborda os escândalos do meio esportivo fazendo uso de manchetes apelativas e irônicas.

Quanto à temática da violência, o jornal dá destaque para crimes bárbaros e de intensa comoção popular, ocorridos em alguma localidade do Rio de Janeiro ou, se de grande relevância, no restante do país. As manchetes, nesses casos, são expressas de modo exagerado, melodramático e sensacionalista. Mas há, porém, vezes em que as notícias sobre violência são tratadas com humor e há ironia, geralmente, quando se retrata a prisão de bandidos. Nota-se também que as manchetes sobre a violência são formadas de modo a chocar e causar emoções diversas no leitor, tal qual: revolta ou indignação.

Segundo um estudo de Duarte e Lannes (2008), o jornal Meia Hora tem um discurso midiático que tende ao espetacular e sensacionalista, a partir da exploração da tríade "erotismo -violência - futebol". A constituição do discurso do jornal também é elaborada para que se estabeleça uma interação com o comportamento e a realidade do público-leitor. 
Estruturalmente, o jornal Meia Hora de Notícias apresenta o formato de tabloide, forma com a metade do tamanho de um jornal do tipo standard, como o Folha de São Paulo ou O Globo, as medidas do jornal apresenta um tamanho médio de $24 \mathrm{~cm}$ de largura por $38 \mathrm{~cm}$ de altura. Graficamente, em sua capa e logotipo, o Meia Hora apresenta as cores vermelho, preto e branco. A capa do jornal é colorida, entretanto, internamente o Meia Hora é predominantemente preto e branco.

As capas do jornal são bastante chamativas, de cores fortes, entre as quais predominam no logotipo o vermelho e o preto. Além da manchete, na qual predomina a cor amarela e preta, de acordo com a imagem de fundo. Segundo Mestriner (2002, p. 53), "a cor constitui-se num elemento de comunicação, provocando estímulo visual como nenhum outro elemento".

Cada cor possui uma característica única. O vermelho é a cor que mais se destaca visualmente e a mais rapidamente distinguida pelos olhos. $O$ amarelo é uma cor fundamental e passa a ideia de atenção. Danger (1973, p. 57), afirma que o vermelho e amarelo são as cores com o melhor poder de atração do público por serem facilmente reconhecíveis e se sobressaírem, fornecendo, assim, incentivo às vendas.

Conforme pode ser visto na llustração 4 - capa 68, de 07 de dezembro de 2012, as cores utilizadas pelo jornal para destacar a manchete e atrair a atenção do público é o amarelo, seguido pelo vermelho utilizado no logotipo e no chapéu da manchete. 


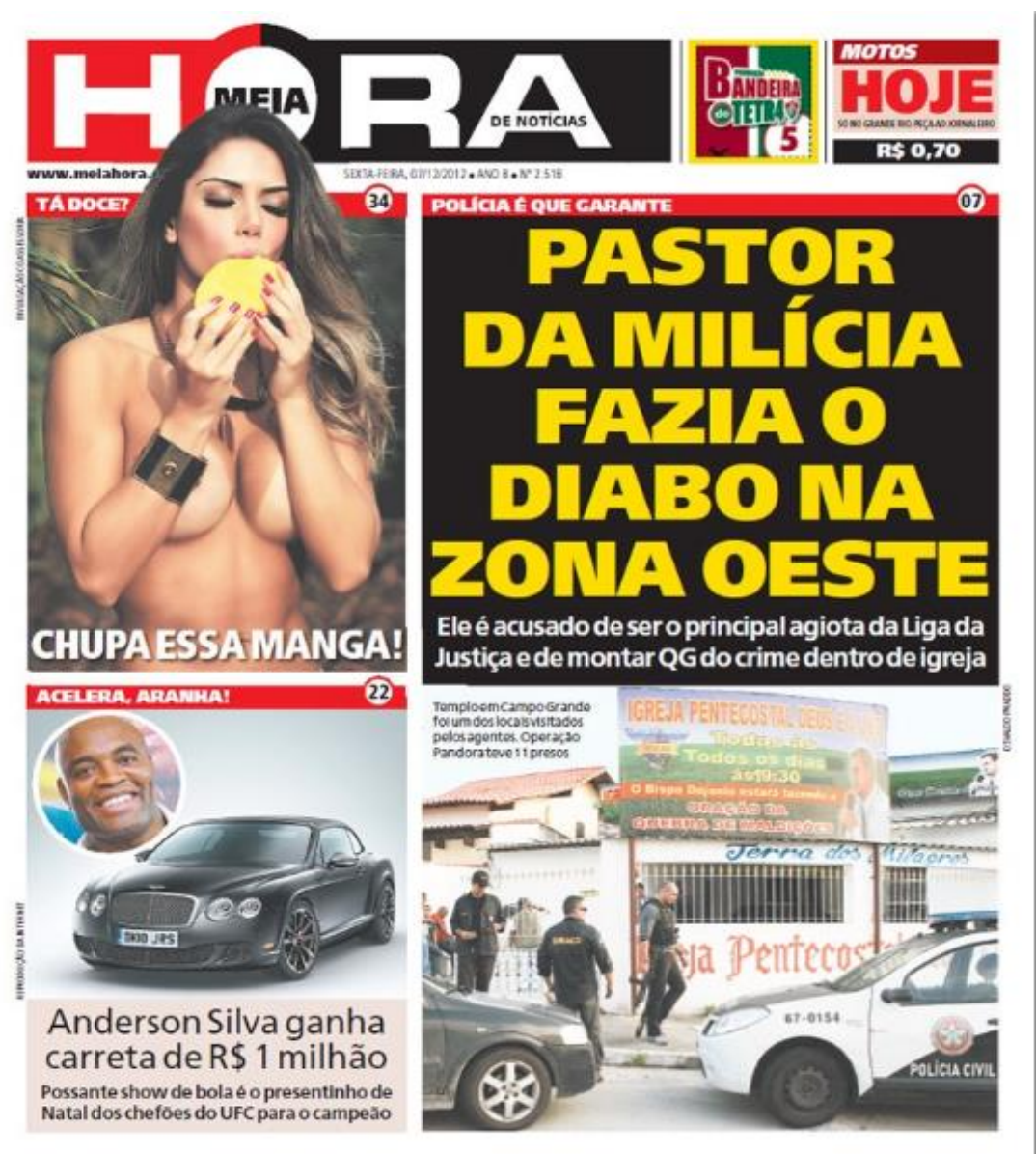

Ilustração 4 - Capa 68-Meia Hora de Notícias (07/12/12)

$\mathrm{Na}$ parte interna do jornal, são apresentadas as vagas de empregos, além de seções de telefones úteis e resultados lotéricos. A seguir, são exibidas as editorias de polícia e notícias em geral; juntas, ocupam entre treze e quinze páginas e estão sempre no início do jornal. Nessa seção, nas segundas, quartas e sextas, encontramos a coluna "Balanço Geral", produzida pelo jornalista Wagner Montes. Às terças, temos a coluna "O Presidente Responde", onde os leitores podem enviar perguntas para serem respondidas pela presidente. Em seguida, há o caderno de Esportes, ocupando onze páginas e localizada na parte central do jornal. No caderno de esportes, são informadas notícias sobre os jogos ocorridos, tabelas de pontuação, notícias sobre os 
jogadores e a coluna fixa "Gata da Hora" que traz fotos sensuais de leitoras torcedoras de algum time de futebol. Logo após, a editoria de Saúde que ocupa uma página. Há também as seções Tecnologia com editorias com conteúdos relacionados às redes sociais e a seção Internacional com notícias sobre o mundo, que ocupam uma página cada.

Como seções variáveis, o Meia Hora apresenta: a "Voz do Povo"; nela, o jornal promove um serviço público com a apresentação de fotos de crianças desaparecidas; Cartas dos Leitores, "Boca no trombone", onde os leitores podem dar suas opiniões sobre fatos atuais; "Corações Solitários", apresentando solteiros se candidatando a possíveis relacionamentos e "Dicionário", um glossário sobre as palavras empregadas na edição e consideradas difíceis.

$\mathrm{Na}$ parte final do jornal, há duas páginas referentes ao "Jornal FM O Dia", com informações sobre a rádio FM O Dia e que pertence ao mesmo grupo de comunicação do jornal. Depois, três páginas são dedicadas à editoria TV, apresentando reportagens, o guia de programação e o resumo das novelas. Há ainda uma página reservada para a coluna "Alto Astral", com a publicação sobre assuntos exotéricos. Duas páginas são designadas ao roteiro cultural da cidade e a última página de conteúdo do jornal é ocupada pela coluna "Babado", sobre fofocas. A quarta capa é destinada ao espaço publicitário. O jornal varia na quantidade de páginas, sendo o Domingo o dia com o maior número delas.

O jornal Meia Hora de Notícias, segundo seu material de divulgação, caracteriza-se por apresentar "capas irreverentes e histórias exclusivas em uma leitura rápida" (EJESA, 2012). 
Dessa forma, para esta pesquisa, foram lidas e observadas 365 capas do jornal Meia Hora de Notícias. Com base numa análise preliminar do corpus colhido, produzimos a tabela a seguir, em relação à temática, num total de 849 ocorrências; tal número refere-se não somente às manchetes, como também aos títulos de notícias e demais elementos presentes na capa do jornal. Especificamos em termos de quantidade, a saber:

\begin{tabular}{|l|l|l|l|l|l|}
\hline \multicolumn{5}{|c|}{ Jornal Meia Hora de Notícias } \\
\hline \multicolumn{5}{|c|}{ Temas apresentados nas manchetes de setembro/2012 a setembro/2013 } \\
\hline Meses & Violência & Futebol & Sexo & TV & Outros \\
\hline set/12 & 26 & 21 & 5 & 11 & 2 \\
\hline out/12 & 29 & 14 & 8 & 15 & 5 \\
\hline nov/12 & 20 & 18 & 9 & 10 & 5 \\
\hline dez/12 & 31 & 8 & 12 & 8 & 10 \\
\hline jan/13 & 26 & 11 & 6 & 11 & 5 \\
\hline fev/13 & 20 & 11 & 10 & 5 & 11 \\
\hline mar/13 & 21 & 16 & 8 & 9 & 10 \\
\hline abr/13 & 26 & 22 & 10 & 3 & 6 \\
\hline mai/13 & 25 & 24 & 10 & 7 & 4 \\
\hline jun/13 & 24 & 23 & 8 & 7 & 4 \\
\hline jul/13 & 24 & 14 & 10 & 5 & 11 \\
\hline ago/13 & 27 & 24 & 10 & 5 & 5 \\
\hline set/13 & 26 & 23 & 3 & 8 & 4 \\
\hline Total & 325 & 229 & 109 & 104 & 82 \\
\hline
\end{tabular}


Podemos observar que o principal tema tratado pelo jornal Meia Hora de Notícias é a violência, com 325 aparições durante o ano. Sobre a temática da violência, as capas do jornal mostram fatos ocorridos na cidade do Rio de Janeiro, abordando crimes, drogas e atos da polícia local. O segundo tema mais visto foi o futebol (229 aparições). Neste tema, o jornal traz notícias sobre os principais times cariocas (Flamengo, Botafogo, Fluminense e Vasco). $\mathrm{O}$ tema sexo aparece em terceiro lugar (109 aparições) e trata de assuntos relacionados ao erotismo, apresentando fotos de mulheres seminuas ou utilizando trocadilhos que remetam à sexualidade. $\mathrm{O}$ quarto tema abordado pelo Meia Hora apresenta tópicos referentes a televisão (104 aparições), citando artistas, novelas e intrigas do meio televisivo. O último tema apresentado - outros (82 aparições) aborda assuntos diversos, geralmente notícias relevantes em todo país, como a vinda do Papa Francisco ao Brasil e o incêndio na boate Kiss em Santa Maria; ou assuntos alusivos à época, como o carnaval no mês de fevereiro.

\subsection{0 perfil do leitor}

De acordo com a empresa de pesquisas Ipsos Marplan ${ }^{5}$, a maioria dos leitores do jornal Meia Hora é masculina e do total de leitores do jornal $64 \%$ pertencem à classe $\mathrm{C}$ e $27 \%$ à $\mathrm{B}$. Quanto à região, $28 \%$ moram na Baixada

\footnotetext{
5 Os dados foram extraídos de www.odiacomercial.com.br/pdf/perfil_leitrores_2012.pdf (consulta em 02/10/2012). Não foi divulgada a tabela de base para o cálculo da Marplan: IBGE ou ABEP, para determinação da classe econômica.
} 
fluminense. Vejamos o quadro que segue:

\begin{tabular}{|c|c|c|c|c|c|}
\hline \multicolumn{6}{|c|}{ PERFIL DOS LEITORES } \\
\hline \multirow{2}{*}{ Sexo } & \multicolumn{3}{|c|}{ Homens } & \multicolumn{2}{|c|}{ Mulheres } \\
\hline & \multicolumn{2}{|c|}{1.220 .000} & & \multicolumn{2}{|c|}{1.104 .000} \\
\hline \multirow{2}{*}{ Classe } & A & B & C & D & $E$ \\
\hline & 23.000 & 587.000 & 1.482 .000 & 221.000 & 10.000 \\
\hline \multirow{2}{*}{ Idade } & $10-19$ & $20-29$ & $30-39$ & $40-49$ & 50 ou + \\
\hline & 414.000 & 635.000 & 508.000 & 374.000 & 393.000 \\
\hline & \multicolumn{2}{|c|}{ Total de leitores } & 2.324 .000 & & \\
\hline
\end{tabular}

Tabela 2 - Perfil dos leitores do jornal Meia Hora de Notícias

De acordo com a tabela 2, o público-leitor situa-se na faixa econômica da classe $\mathrm{C}$, que tem ascendido do ponto de vista econômico em relação ao consumo de bens materiais e ingressado aos poucos em cursos superiores; porém, a história ainda não mudou: a escolaridade média dessa faixa econômica continua baixa. Então, alguns recursos gráficos empregados nos títulos dos jornais, resguardadas as variantes, podem não ser entendidos pelos leitores. O uso das aspas, por exemplo, pode ou não advertir o leitor sobre possíveis efeitos de sentido. Outros recursos, como o emprego de letras maiúsculas no meio da frase (no título) na indicação de nomes próprios podem passar despercebidos.

As classes econômicas no Brasil são medidas pelo Critério de Classificação Econômica do Brasil (CCEB), passando a haver no país uma unidade em torno desse sistema no que se refere à classificação dos 
consumidores em categorias econômicas. O CCEB tem como função estimar o potencial de compra das famílias e segmentar o mercado em classes sociais. Porém, não pretende dividir a sociedade em classes sociais. Esse critério tem como parâmetros a atribuição de pontos à quantidade de determinados itens que o indivíduo possui - considerando dez itens. As classes sociais, nesse critério, ficam assim subdivididas: A1, A2, B1, B2, C, D. Os itens ficam distribuídos da seguinte maneira:

\begin{tabular}{|c|c|c|c|c|c|}
\hline Itens & Não tem & Tem 1 & Tem 2 & Tem 3 & Tem 4 ou + \\
\hline TV & $\mathbf{0}$ & 2 & 3 & 4 & 5 \\
\hline Rádio & $\mathbf{0}$ & 1 & 2 & 3 & 4 \\
\hline Banheiro & $\mathbf{0}$ & 2 & 3 & 4 & 4 \\
\hline Carro & $\mathbf{0}$ & 2 & 4 & 5 & 5 \\
\hline Empregada & $\mathbf{0}$ & 2 & 4 & 4 & 4 \\
\hline Aspirador de pó & $\mathbf{0}$ & 1 & 1 & 1 & 1 \\
\hline Máq. Lavar & $\mathbf{0}$ & 1 & $\mathbf{1}$ & $\mathbf{1}$ & $\mathbf{1}$ \\
\hline Video/DVD & $\mathbf{0}$ & 2 & 2 & 2 & 2 \\
\hline Geladeira & $\mathbf{0}$ & 2 & 2 & 2 & 2 \\
\hline Freezer & $\mathbf{0}$ & 1 & 1 & 1 & 1 \\
\hline \multicolumn{5}{|c|}{ Grau de instrução do chefe de família } & Pontuação \\
\hline \multicolumn{5}{|c|}{ Analfabeto/primário incompleto } & $\mathbf{0}$ \\
\hline \multicolumn{5}{|c|}{ Primário complete / ginasial incompleto } & 1 \\
\hline \multicolumn{5}{|c|}{ Ginásio completo / colegial incompleto } & 2 \\
\hline \multicolumn{5}{|c|}{ Colegial incompleto / superior incompleto } & 3 \\
\hline \multicolumn{5}{|l|}{ Superior complete } & 5 \\
\hline \multicolumn{5}{|c|}{ Classe } & Pontos \\
\hline \multicolumn{5}{|c|}{$\mathbf{A 1}$} & $30-34$ \\
\hline \multicolumn{5}{|c|}{$\mathbf{A 2}$} & $26-29$ \\
\hline \multicolumn{5}{|c|}{ B1 } & $21-24$ \\
\hline \multicolumn{5}{|c|}{ B2 } & $17-20$ \\
\hline \multicolumn{5}{|c|}{$\mathbf{C}$} & $11-16$ \\
\hline \multicolumn{5}{|c|}{$\mathbf{D}$} & $6-10$ \\
\hline
\end{tabular}

Tabela 3 - Classificação econômica dos consumidores brasileiros ${ }^{6}$

De acordo com o sistema CCBE, classificam-se as pessoas profissionalmente, segundo sua classe social. Assim, os profissionais mais

\footnotetext{
${ }^{6}$ ABEP - Associação Brasileira de Empresas de Pesquisa. Página eletrônica disponível em http://www.abep.org.br. Acesso em 12 de junho de 2014.
} 
comuns na classe A são os banqueiros, empresários, políticos (de cargos de alto escalão), grandes agricultores, diretores de empresas nacionais e multinacionais, pessoas ligadas à arte e à cultura (de fama internacionalmente reconhecida) e, mais recentemente, técnicos científicos ligados à área tecnológica e de telecomunicações. Os profissionais da classe B são os escriturários de grandes empresas, bancários, médicos, profissionais liberais e autônomos. Os profissionais da classe C são os viajantes, trabalhadores do transporte e comunicação, trabalhadores de processos de produção, professores, enfermeiros, profissionais com cursos de especialização (mecânica, elétrica, corte e costura, etc). Os profissionais da classe D são os trabalhadores da construção civil, as empregadas domésticas, os trabalhadores rurais e o trabalhador autônomo de pequeno porte (costureira, faxineira, encanador), que fazem parte do trabalho informal.

O brasileiro da classe C, perfil do leitor do jornal Meia Hora de Noticias, nas últimas décadas, representa um nicho dentro da representação da classe C como um todo deixou de ser visto como um mero coadjuvante e tem ocupado um papel cada vez maior na economia do país. Diferente de há vinte anos, quando havia bem menos produtos e tudo era menos acessível, hoje existe uma grande concorrência, o que gera uma guerra de preços e economia mais equilibrada.

Segundo Flauzino (2008) em um novo cenário econômico brasileiro, a classe $\mathrm{C}$ consome mais e com qualidade e o abismo social tem ficado menor. Graças ao crédito, o consumidor das classes "menos favorecidas" mostra que tem grande potencial. O Brasil não deixou de ser um dos piores países em distribuição de renda, mas depois de quase uma década e meia de aumento do 
abismo social, uma transformação vem ocorrendo, no sentido oposto.

Com base nas pesquisas realizadas pelos vários órgãos de pesquisas, no Brasil, pode-se dizer que classe $C$ tem mudado de maneira drástica seus hábitos de consumo e está no topo das táticas de grandes empresas. Com o aumento da renda e do emprego, crédito em ascensão e programas sociais, essa camada passou de 36\% em 2006 para 46\% em 2007, ou seja, 20 milhões de brasileiros saíram da pobreza e passaram a integrar a classe que hoje consome mais de $R \$ 410$ bilhões, segundo Flauzino (2008). 


\section{PARTE II - ANÁLISE DO CORPUS}

\section{Capítulo 5. 0 Corpus}

As ocorrências observadas no levantamento feito especificamente para o corpus da análise foram numeradas para efeito de permitir as devidas remissões na análise, conforme Anexo 1 (Tabulação - capas dos jornais Meia Hora de Notícias - 01/10/2012 a 30/09/2013)

Abaixo apresentamos a tabela de manchetes divididas em 3 temas objetos da dissertação, isto é: violência, futebol, sexo e incluímos uma lista de outros temas também encontrados.

Consideramos, para separação das manchetes, os seguintes conceitos sobre os temas com os quais trabalharemos. O primeiro, e com o maior número de aparições, é a violência, segundo (Michaud, 1989) pode ser entendida como a ação de um indivíduo ou grupo contra uma ou mais pessoas a fim de causar danos. Além disso, existe violência quando a ação causa constrangimentos não apenas físicos, mas também psicológicos e morais. Finalmente, é preciso incluir a violência simbólica, que não causa a morte física, mas atenta contra as crenças, a cultura e a própria identidade dos indivíduos que dela são vítimas. Concluindo, entende-se como violência tudo aquilo que não é desejado pelo outro, e que lhe é imposto pela força concreta ou simbólica (falta do necessário à vida; necessidade, fome, miséria). As manchetes que abordam tal temática trazem notícias sobre o tráfico de drogas, a violência na cidade do Rio de Janeiro, a polícia carioca, mortes e roubos.

O segundo tema trata do futebol, jogo popular no Brasil. As manchetes falam sobre os 4 times cariocas (Flamengo, Botafogo, Fluminense e Vasco. $\mathrm{O}$ 
foco é dividido entre os times e os jogadores famosos, cujos atos também acabam nas manchetes do Meia Hora.

Há também manchetes que abordam temas relacionados ao sexo, onde há o uso de ambiguidade para se tratar sobre a relação sexual e o uso de imagens de mulheres seminuas.

Ainda constatamos a presença de manchetes que abordam temas relacionados ao cotidiano da cidade do Rio de Janeiro ou acontecimentos importantes no país.

A tabela abaixo enumera as capas, especificando em qual dos eixos temáticos ela se adéqua melhor.

\begin{tabular}{|c|c|c|c|}
\hline Violência & Futebol & Sexo & Outros \\
\hline 24910121314 & 3531343542 & 2125283254 & 16811232439 \\
\hline 1516171819 & 4353557478 & 8081115145 & 4445474951 \\
\hline 2022262729 & 84143155156 & 150170187189 & 6164657273 \\
\hline 3033363738 & 162163183196 & 199200204215 & 7782868889 \\
\hline 4041464850 & 209214217218 & 223235258273 & 92939697101 \\
\hline 5256575859 & 220227242246 & 310311322328 & 105107108113 \\
\hline 6062636667 & 265268271274 & 334335 & 119121126128 \\
\hline 6869707175 & 275306307317 & & 133135137140 \\
\hline 7679838587 & 332340348356 & & 144147151153 \\
\hline 9091949598 & 358365 & & 154157158161 \\
\hline 99100102103 & & & 165166176177 \\
\hline 104106109110 & & & 180182201203 \\
\hline 111112114116 & & & 205231233237 \\
\hline
\end{tabular}




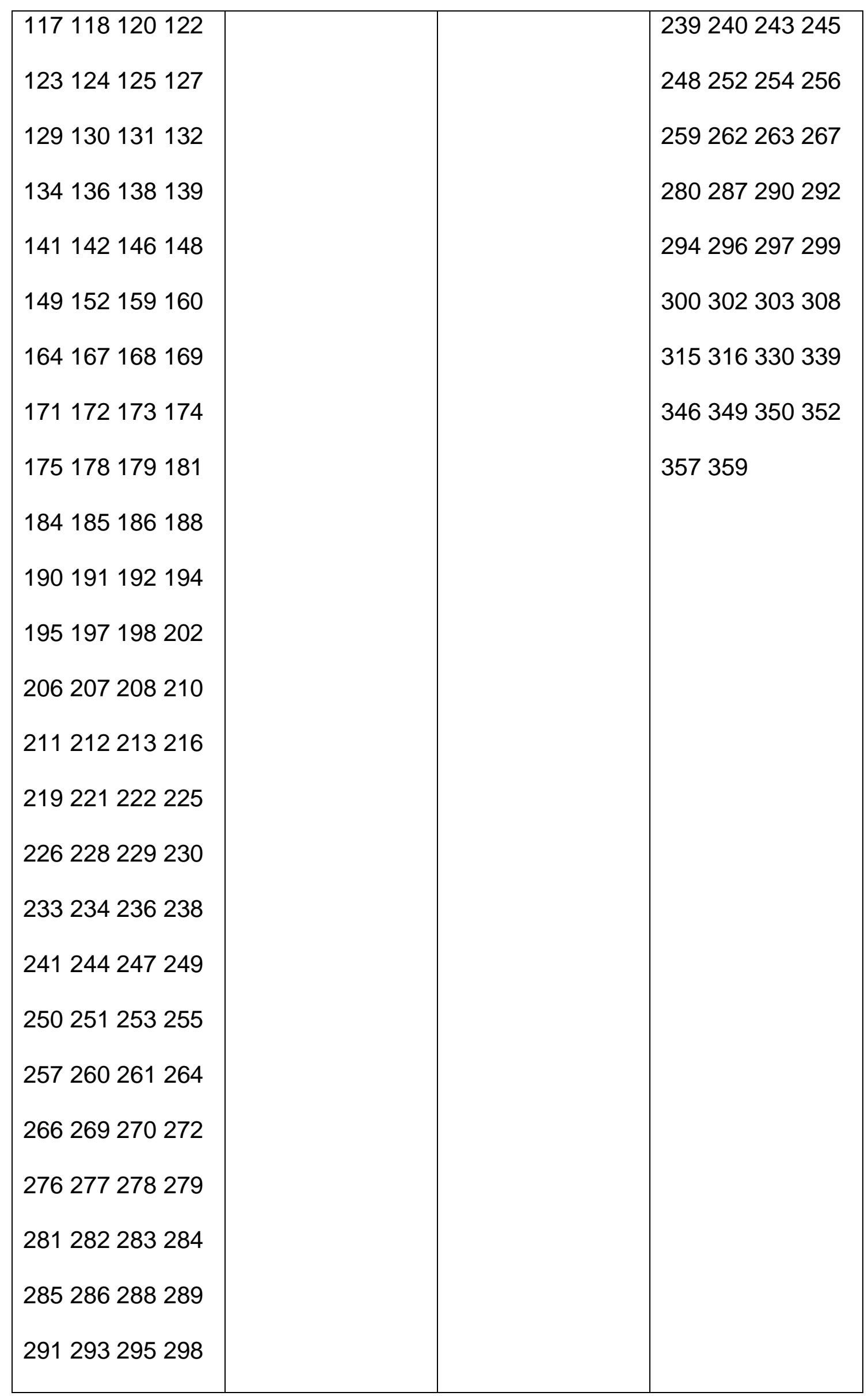




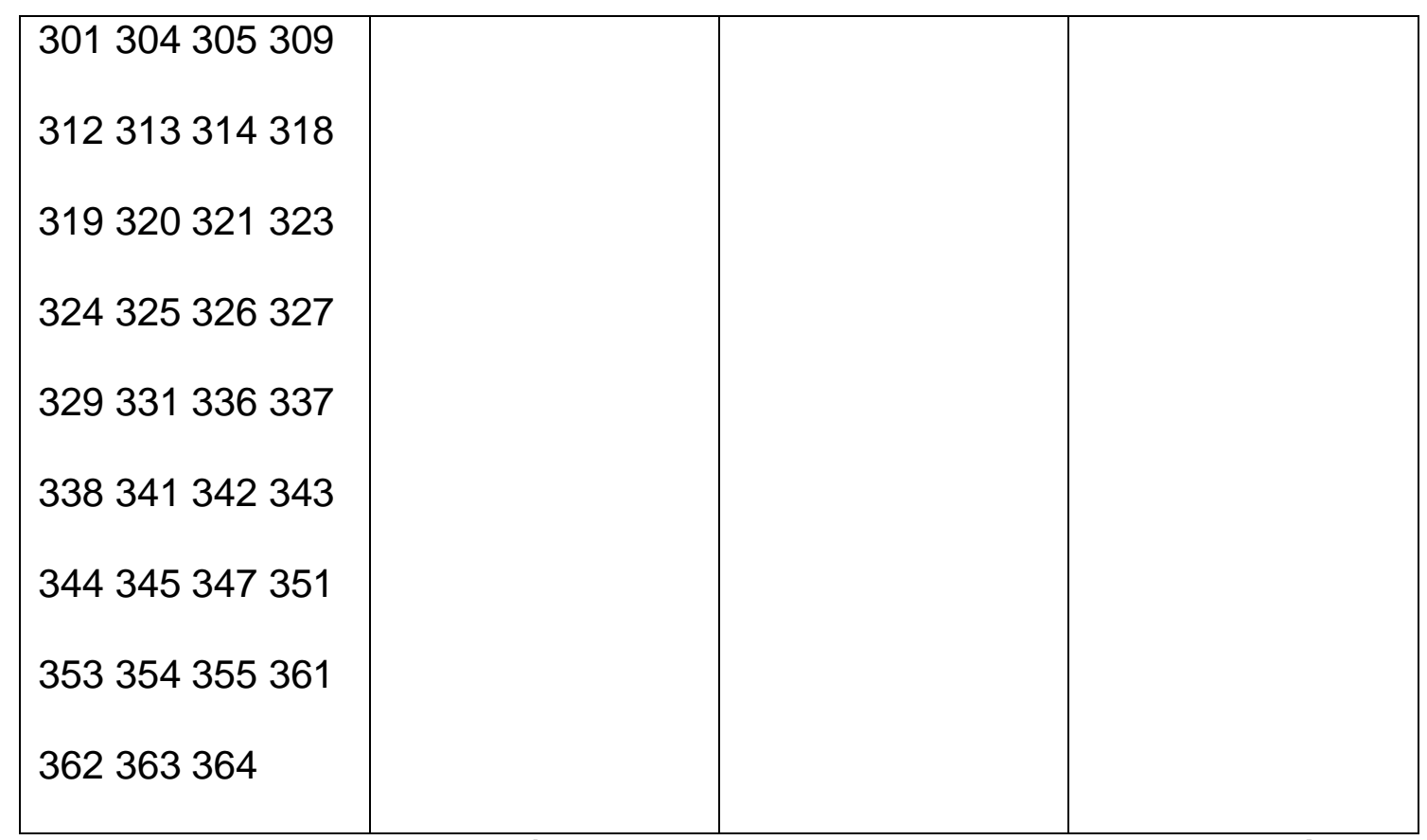

Tabela 4 - Indicação da temática das manchetes do jornal Meia Hora de Notícias

Com base nos estudos de Marcuschi (2007) e Koch (2008) e Urbano (1998, 2000, 2006 e 2011) a respeito da fala e da escrita e nos conceitos de Charaudeau (2006) sobre os papéis dos sujeitos envolvidos no ato da linguagem, analisamos o jornal Meia Hora de Notícias e as marcas de oralidade existentes. Utilizamos uma classificação baseada em Dias (2003) para tratar dessas marcas encontradas no jornalismo popular, dividida em dois níveis: pragmático/discursivo e linguístico. Assim como Dias (2003) observou em seu estudo a respeito da linguagem do jornalismo popular, também constatamos que o texto do Meia Hora de Notícias não é uma transcrição da língua falada, mas todos esses recursos empregados tentam se aproximar o máximo possível desse tipo de linguagem, o que resulta em um texto escrito permeado de características da oralidade, o que pode ser justificado pelo continuum tipológico (Marcuschi, 2007). 
Focamos o nosso estudo na estrutura da manchete das capas do Meia Hora de Notícias. Na ilustração a seguir, esclarecemos ao leitor o que entendemos por manchete e quais são as partes analisadas.

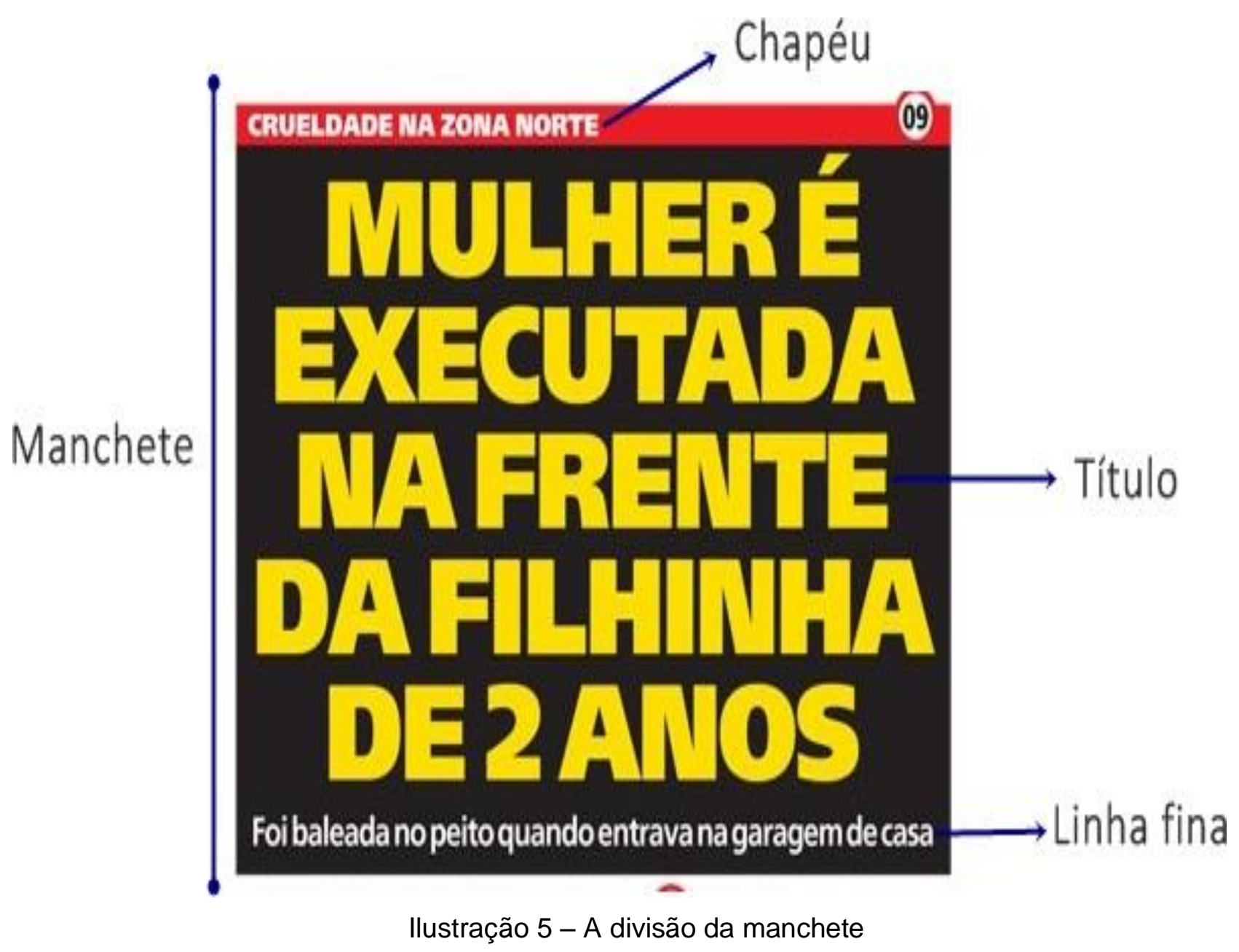

Fizemos essa escolha porque, além de observarmos maior presença de marcas da oralidade nesses textos, também verificamos, em nossos estudos a respeito de jornalismo popular, que essa linguagem de capa é a maior responsável pela vendagem dos jornais, exatamente porque traz uma variação linguística marcada por expressões coloquiais, mais do que qualquer outra seção do periódico. Consequentemente, seria importante para o nosso estudo verificarmos o que estaria relacionado a essa linguagem de capa dentro do 
jornal. E constatamos que também há o emprego de muitos recursos da linguagem popular nessa estrutura interna, quase todos concentrados no chapéu e no título da notícia. A linha fina e o lide apresentaram poucas variações.

Em nosso primeiro contato com o corpus coletado, realizamos uma observação de todos os elementos presentes na capa do jornal; a partir de tal observação, criamos a tabela que apresenta a divisão do jornal dentre os três temas principais já citados (Violência, futebol e sexo), além do tema "outros", que conforme explicação anterior sugere temas relativos acontecimentos relevantes no dia da publicação.

Após tal tabulação, decidimos voltar nossa análise apenas para as manchetes na tabela que segue como anexo 1, numeramos as 365 manchetes do jornal; tal tabela visa facilitar a consulta do leitor desta dissertação. As manchetes foram tabuladas de acordo com a temática e divididas em: violência, tema de maior ocorrência, com 197 aparições; futebol, com 41 aparições; e sexo, com 27 ocorrências. A divisão, também, pode ser facilmente identificada pelo sistema de cores utilizado na tabela: Vermelho - violência, amarelo - futebol, roxo - sexo e verde - outros.

Para análise mais apurada, escolhemos 30 manchetes que exemplificaram de modo satisfatório a teoria empregada. Porém, como pode ser visto nos anexos, em todas as 365 capas do jornal Meia Hora de Notícias ocorrências de oralidade puderam ser encontradas.

A lista a seguir traz as 30 manchetes do Jornal Meia Hora de Notícias em que se analisam as marcas de oralidade, representadas por enunciados cuja intenção subjetiva é a aproximação com o leitor. 
Nessa terceira tabulação do corpus, além das manchetes, apresentamos também o chapéu e a linha fina, pois estes são importantes complementos da manchete e podem ajudar na análise e compreensão da informação.

A análise está sistematizada em diversos níveis e aspectos, a saber: 0 primeiro nível de análise é pragmático/discursivo e divide-se nos subníveis: narrativo, língua culta x Língua popular, fórmulas fixas, frases triádicas e envolvimento do narrador. O próximo nível analisado é o linguístico que dividese em: fonético, lexical, sintático e semântico / lexical.

\subsection{Nível pragmático/discursivo}

Segundo Charaudeau e Maingueneau (2008), o nível discursivo é o lugar onde se estabelecem as diversas formas de dizer do sujeito, seus modos de falar e os papéis linguajeiros que deve ter. Nesse nível de discurso, o sujeito usa diferentes procedimentos de encenação discursiva. Observamos que no jornal esses procedimentos que se aproximam da oralidade são variados. Em nosso estudo, destacamos para análise: as notícias em forma de narrativas; a linguagem com variações culta e popular ao mesmo tempo; as fórmulas fixas; as frases verbais triádicas; e o envolvimento do redator nos textos. Selecionamos algumas das amostras estudadas para exemplificar a presença desses recursos na linguagem do jornal.

\subsubsection{Narrativa}

Em relação ao nível narrativo, Dias (1996, p.63) confirma que o envolvimento do redator muitas vezes estabelece um efeito narrativo muito 
próximo da conversação, "criando-se um estilo de narrar que se aproxima da oralidade e que nos surpreende nos momentos menos esperados". Ainda segundo a autora, o jornalismo popular busca atender a uma expectativa do leitor, assim como no discurso oral, cujo falante tem interesse em satisfazer às expectativas do seu interlocutor.

\section{VÍTIMA É UM BEBEZINHO DE 10 MESES!}

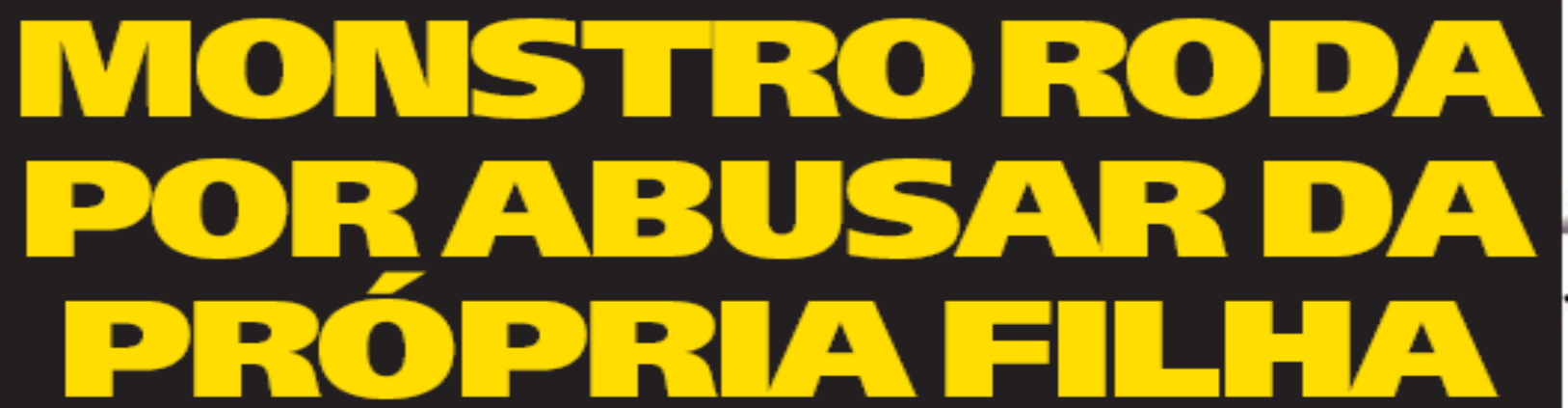

Esposa viu vídeo comprometedor no celular do tarado, e ele acabou sendo levado para a prisão pelo irmão, que é da PM

llustração 6 - Capa 206

Podemos ver que nesse título de notícia, referente à capa 206, o estilo de narrativa é típico do jornalismo popular, pois permite um maior envolvimento do leitor com a história, assim como na ficção escrita, que utiliza estratégias relacionadas à língua falada, a fim de permitir uma maior proximidade e identificação do leitor com o texto.

Existindo essa aproximação entre jornalismo e ficção no quesito envolvimento (da língua falada) e integração (da língua escrita), verificamos que de acordo com a proposta de distribuição bidimensional de traços funcionais em quatro gêneros (texto científico, ficção, discussão acadêmica e conversação), de Marcuschi (1993), podemos encontrar traços de similaridade do texto jornalístico popular com a conversação espontânea. 
Segundo Dias (1996), o jornal popular institui com seus leitores uma interação próxima da conversação, com o intuito de que o discurso soe familiar. Isso é possível graças ao fator de envolvimento e pela recuperação de roteiros conhecidos, que são típicos da narrativa ficcional, possibilitando, assim, a satisfação da necessidade do leitor de ser informado.

Análises semelhantes podem ser aplicadas nas ocorrências que seguem a seguir.

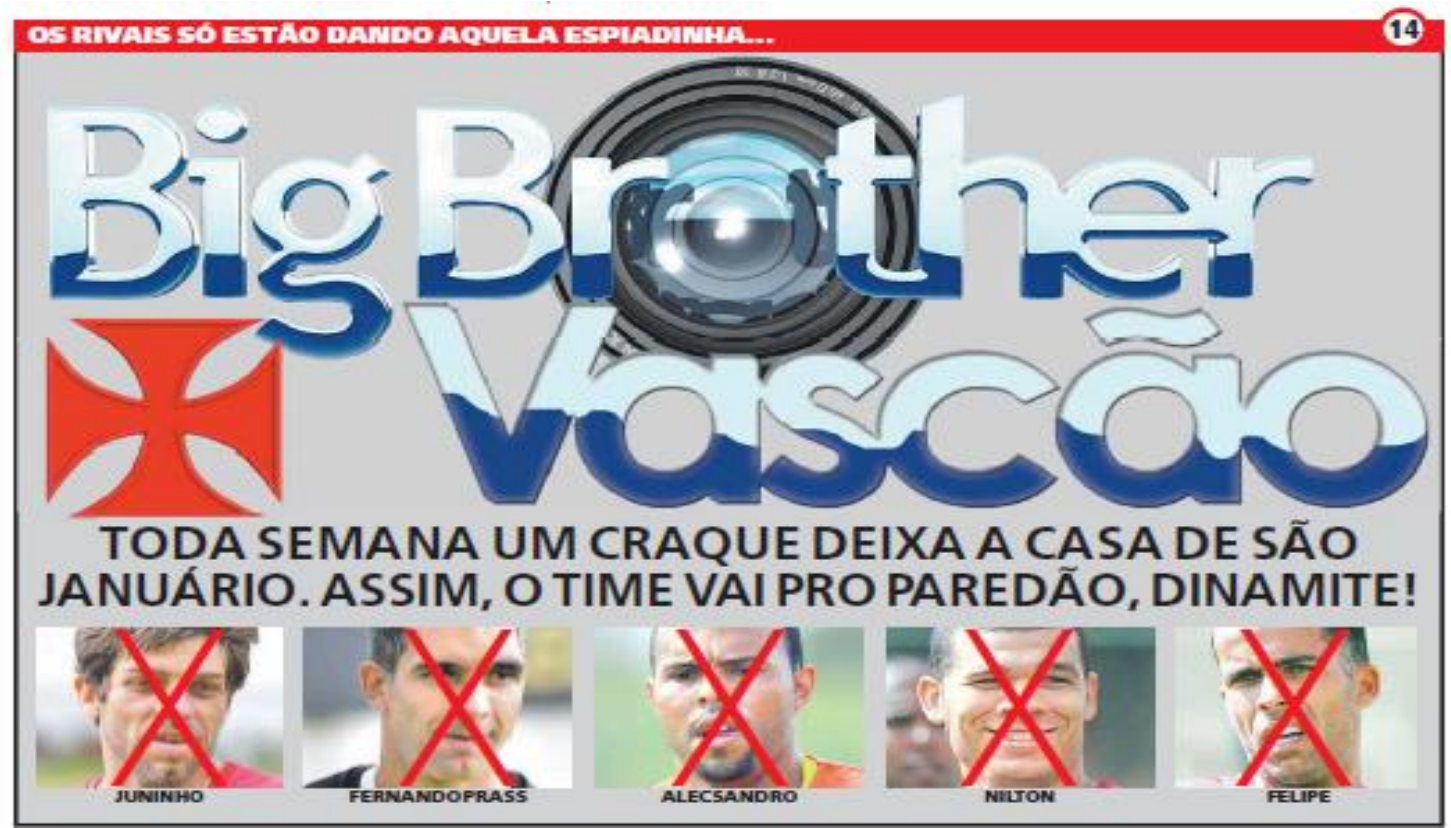

llustração 7 - Capa 84

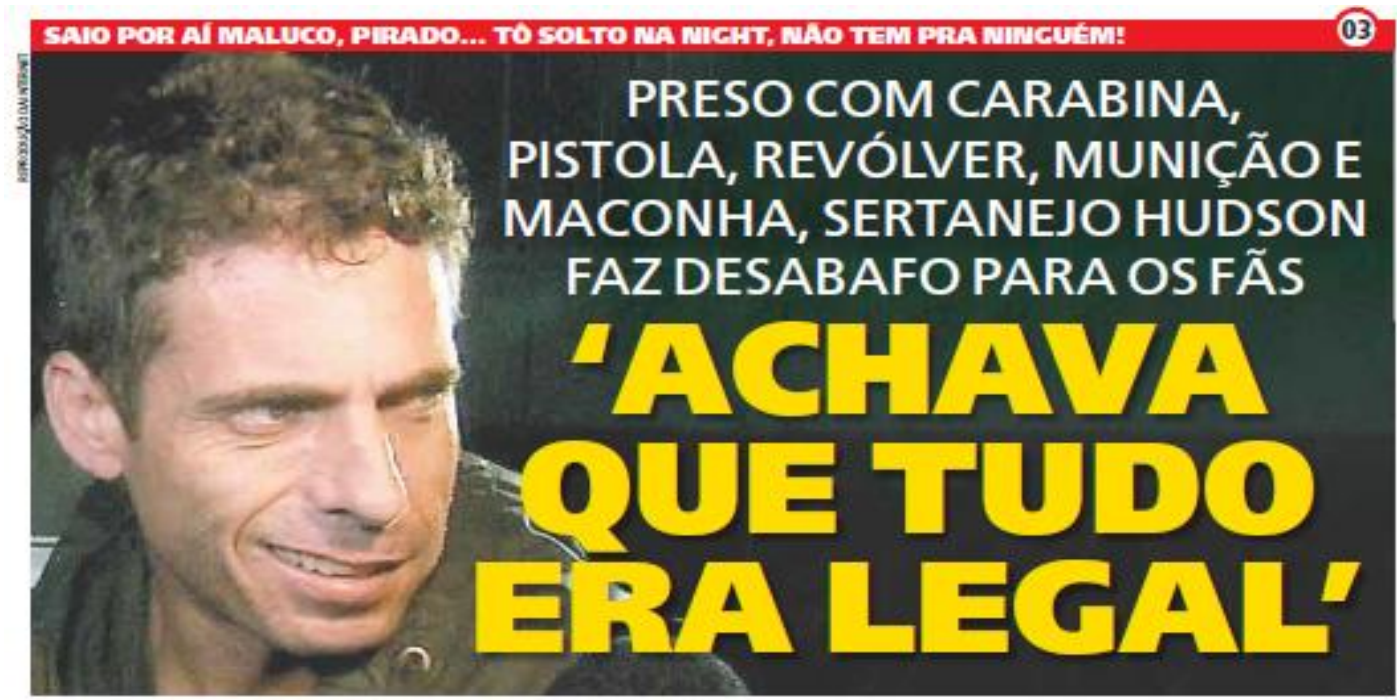

llustração 8 - Capa 173 


\subsubsection{Língua culta x Língua popular}

Encontramos uma variação entre o estilo culto da linguagem e o estilo popular principalmente quando relacionamos manchetes com notícias. Normalmente, os títulos de notícia abusam da linguagem popular, mas a linha fina segue a estrutura do jornalismo tradicional, utilizando uma linguagem de acordo com os manuais de redação.

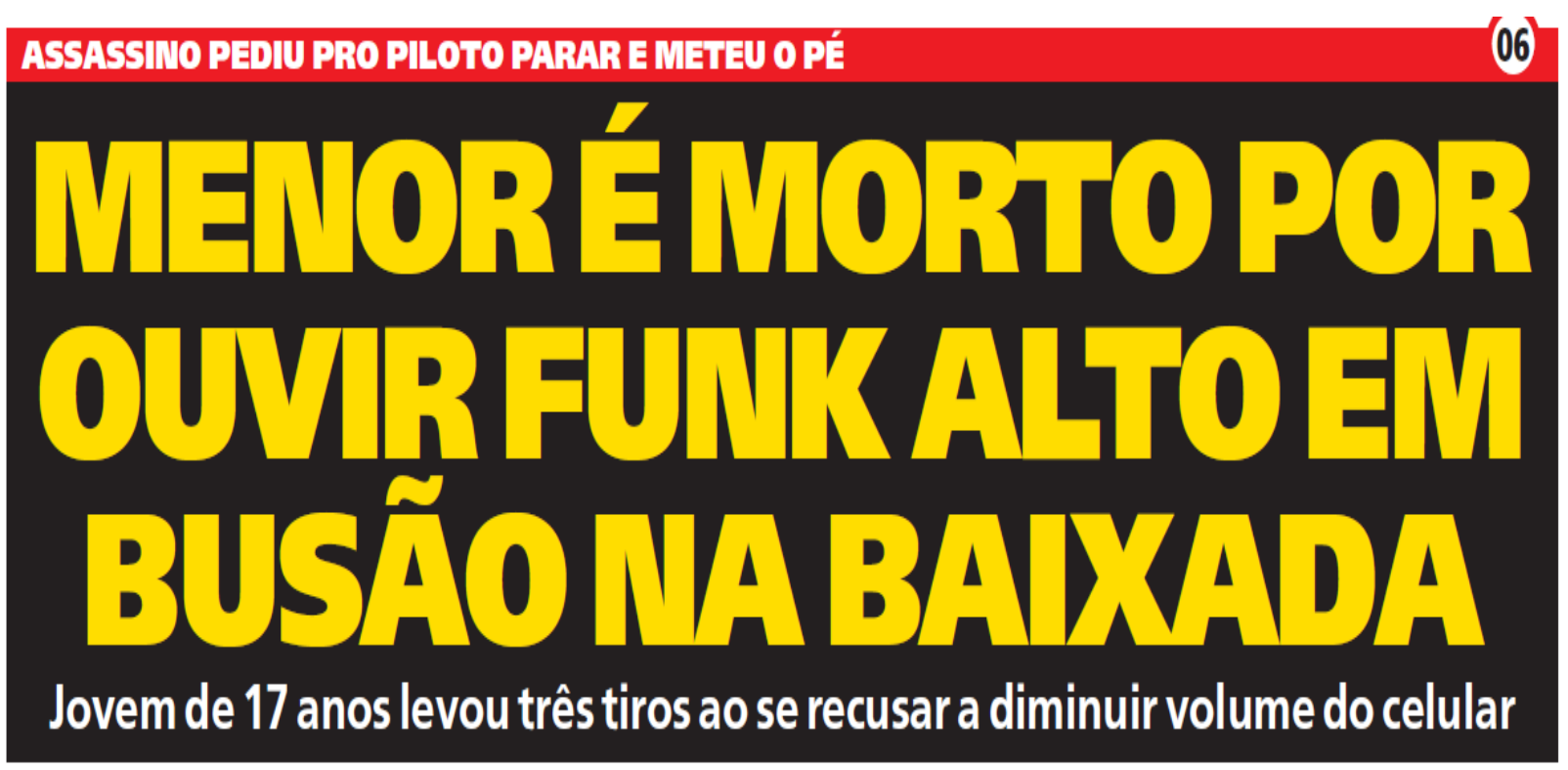

llustração 9 - Capa 26

Na manchete da capa 26, o jornal utiliza uma linguagem coloquial típica da língua falada ao se referir ao jovem morto, como "menor", lexia comumente utilizada quando se refere a pessoas menores de dezoito anos. Ainda há o termo gírio "busão", termo utilizado para designar o ônibus. No chapéu aparecem os termos: "piloto" referente a motorista e "meter o pé" para dizer "fugir". No entanto, no título de notícia o estilo jornalístico se mantém muito próximo da norma culta, sem a presença de itens lexicais que caracterizam uma fala popular. Enquanto a manchete utiliza "menor" a linha fina utiliza "jovem". 
Na capa a seguir (capa 56), o chapéu "Assassinato de Eliza Samudio" e a linha fina "Para a promotoria, condenação de Macarrão indica que goleiro vai ser considerado culpado", há o uso de linguagem formal, não há a presença de gírias e observa-se o uso formal da preposição "para" mais artigo "a" em "Para a", diferente do que ocorre na manchete, na qual se usa a forma reduzida e ligada à fala "pra". Na manchete, há também o uso da expressão "cana dura" para se referir à prisão.

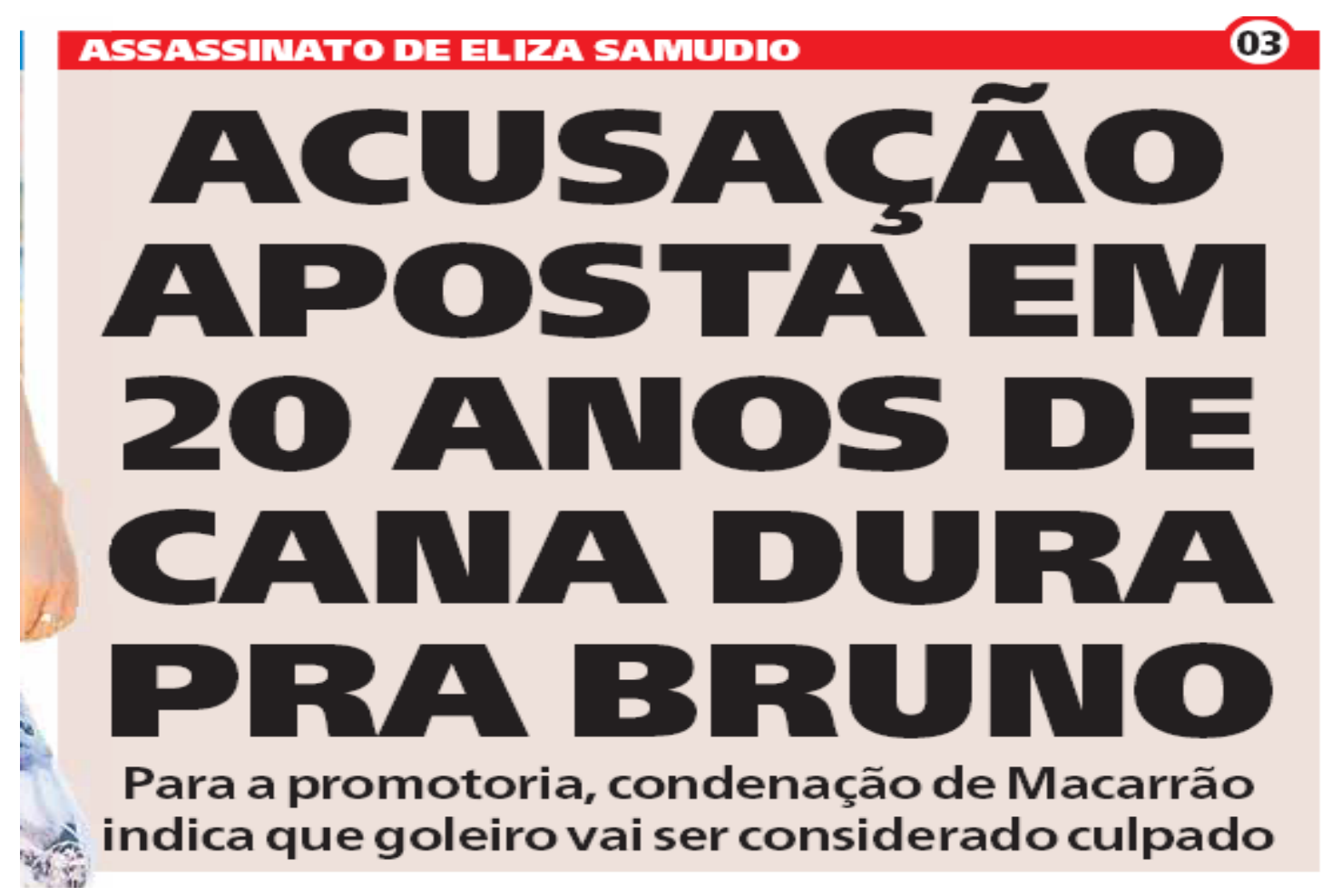

llustração 10 - capa 56

Análise semelhante pode ser notada na capa 114, na qual se nota o uso da gíria "quebrar" cujo sentido na manchete não é o sentido literal de destruir algo, mas sim de "fazer algo dar errado", "estragar os planos de outrem". Já na linha fina podemos observar o uso da voz passiva, forma culta e a indicada pelos manuais de redação. 


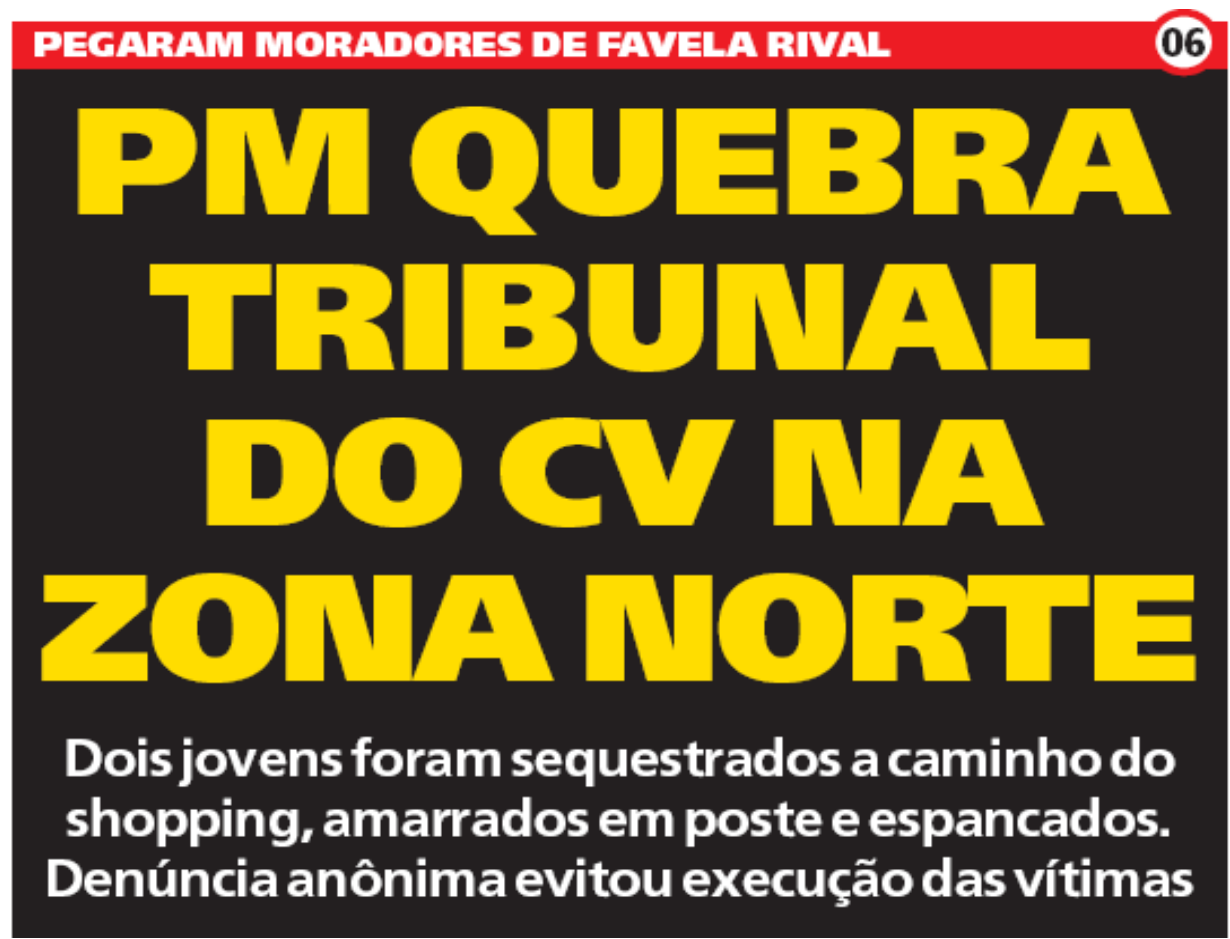

Ilustração 11 - capa 114

\subsubsection{Fórmulas fixas}

De acordo com Charaudeau e Maingueneau (2008), uma fórmula fixa caracteriza-se pelo seu uso constante, sua circulação em um espaço público em uma determinada conjuntura, constituindo-se como objeto de amplo conhecimento partilhado. Assim, fórmulas fixas são expressões ditas como comentários em circunstâncias particulares, como as frases feitas, os ditados populares ou os provérbios, que surgem com certa frequência no Meia Hora de Notícias. Tais recursos discursivos são utilizados como uma forma de provocar uma identificação pessoal do público com expressões as quais fazem parte do seu cotidiano, constituindo certa intimidade. São bem comuns na língua falada, pois servem para manifestar as mesmas opiniões, sem muitas variantes. 
Segundo Nóbrega (2008, p. 105):

Fórmulas fixas são blocos de palavras ou frases repetidas e rotineiras, falados a todo instante por inúmeros usuários em determinados contextos. Entre essas fórmulas fixas consideramos os clichês, os chavões, os lugares-comuns, as frases feitas e os provérbios.

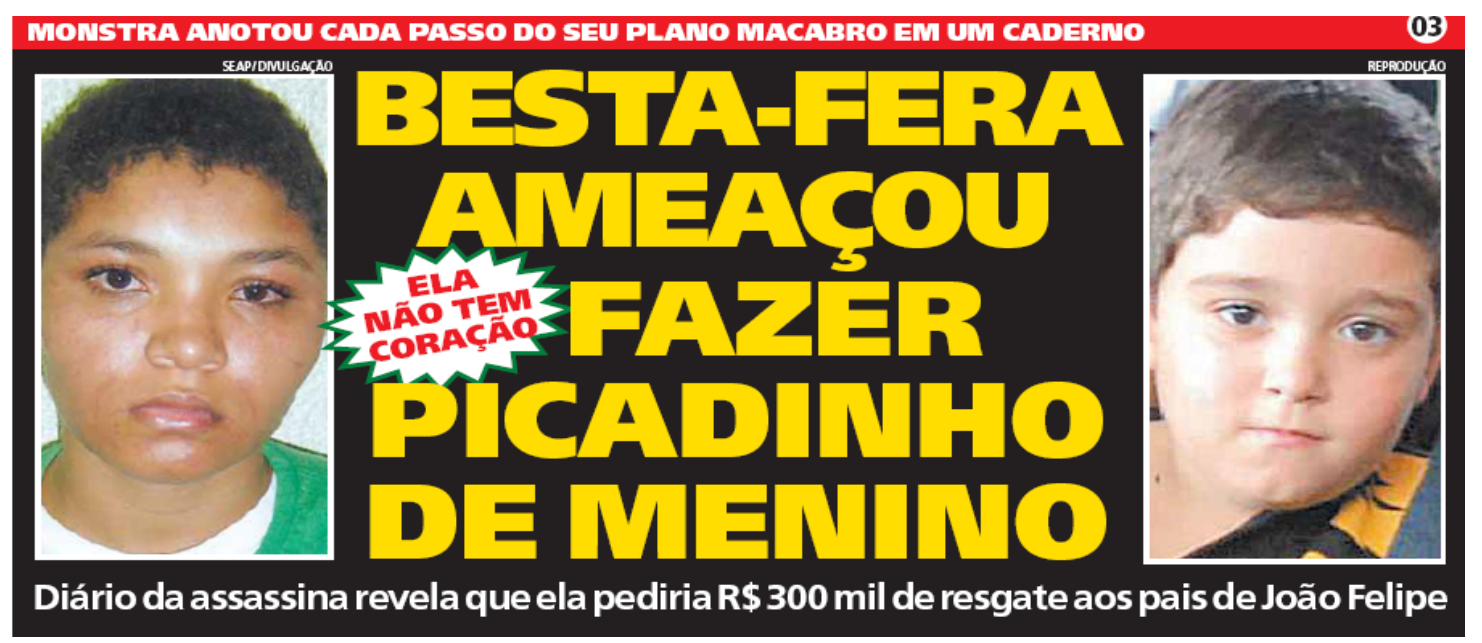

llustração 12 - Capa 26

No caso acima (capa 26), observamos a utilização da expressão popular "fazer picadinho" (matar). É uma expressão coloquial utilizada na língua corrente, ou seja, típica da língua falada do cotidiano, particularmente em determinados grupos sociais. No entanto, a intencionalidade e informalidade do texto no jornalismo popular permitem a utilização de tais expressões na língua escrita.

Nestes outros exemplos abaixo, as expressões populares são compostas por vocabulário gírio (por exemplo, apodrecer), utilizado na oralidade. Muitas delas já se tornaram comuns nas classes A e B, outras ainda se mantêm restritas às classes mais populares. 


\section{VÍTIMA É UM BEBEZINHO DE 10 MESES!}

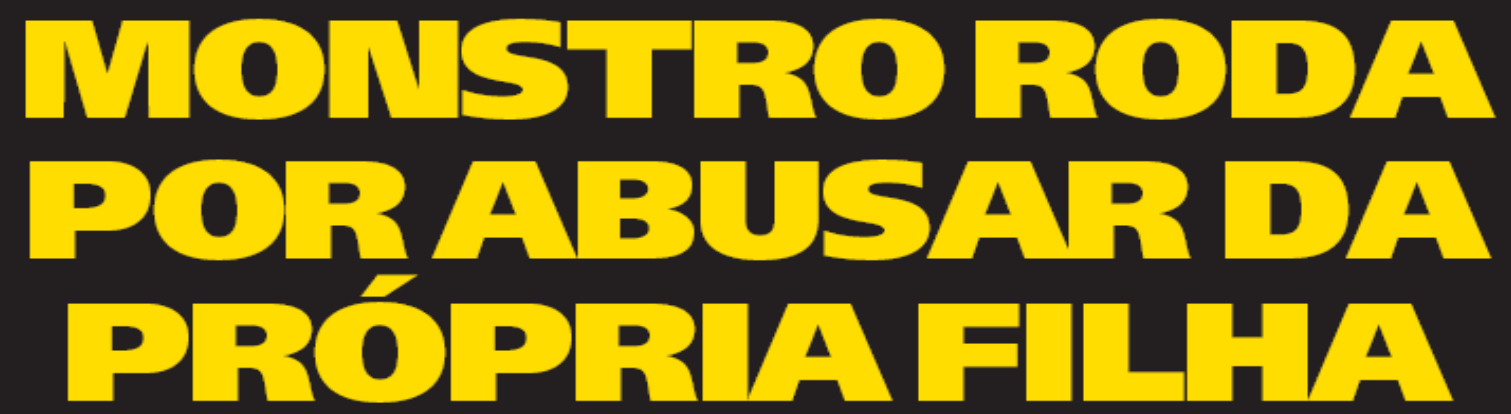

Esposa viu vídeo comprometedor no celular do tarado, e ele acabou sendo levado para a prisão pelo irmão, que é da PM Ilustração 13 - Capa 206

Neste outro exemplo (capa 125), temos no título as expressões "semnoção" (indivíduo desatento ou alheio à realidade) e "dar o bote" que indica atacar.

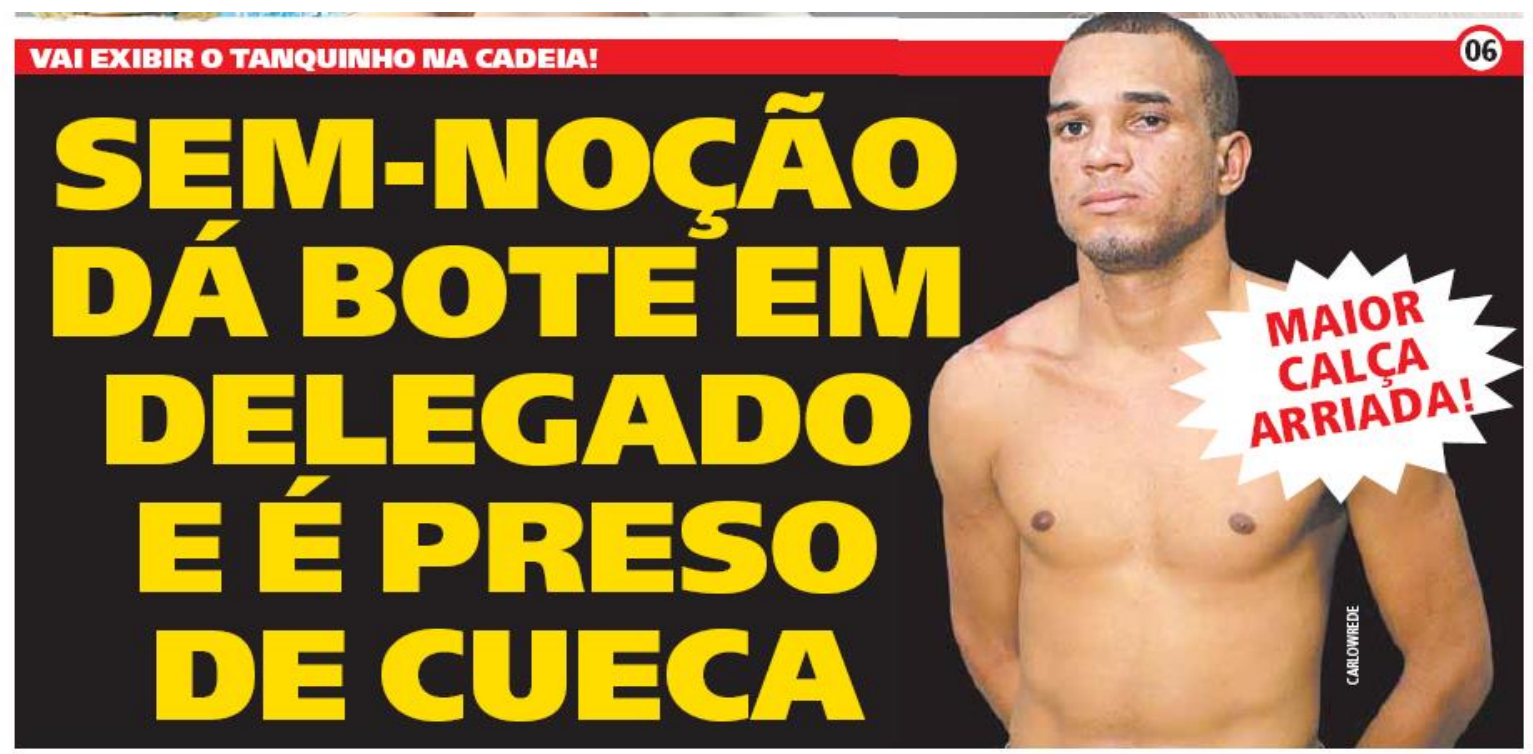

Ilustração 14 - Capa 125

Segundo Carvalho (1996), nem sempre essas expressões são usadas literalmente. Pode-se inserir um novo elemento e criar um jogo de palavras que altera a frase feita, de modo a desmontar estereótipos. Seu uso é bastante difundido nos meios de comunicação de massa, sobretudo no jornalismo e na publicidade. 
O receptor, ao ativar seus esquemas mentais, descobre algo familiar e o traduz, de acordo com uma leitura particular, por meio de projeções, que, por sua vez, são resultado de um legado comunitário. O processo se dá a partir da memória particular de cada um, mas constitui o fio condutor que leva ao âmago da própria cultura. (Carvalho, 1996, p.85)

$\mathrm{Na}$ capa a seguir, observamos uma fórmula fixa que sofreu uma adaptação; tal retextualização tem a intenção de parodiar a frase original e gerar um efeito de humor e crítica. A frase original "E o salário ó", se trata de um bordão sempre citado ao fim do programa humorístico "Escolinha do professor Raimundo", exibido nos anos 90 na Rede Globo e apresentado pelo humorista Francisco "Chico" Anysio de Oliveira Paula Filho.

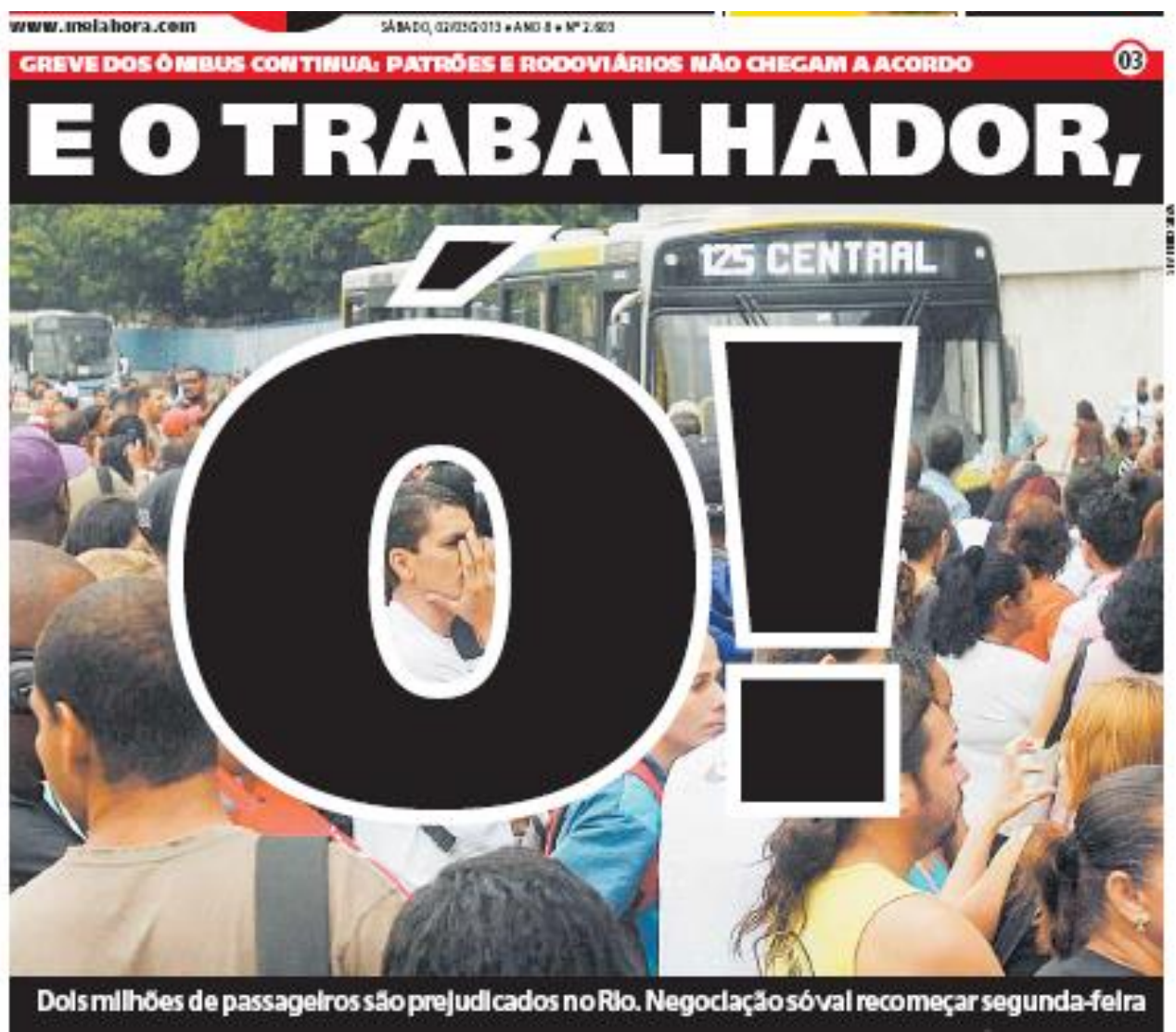

llustração 15 - Capa 153 
No chapéu da capa 331 também se observa o uso da fórmula fixa.

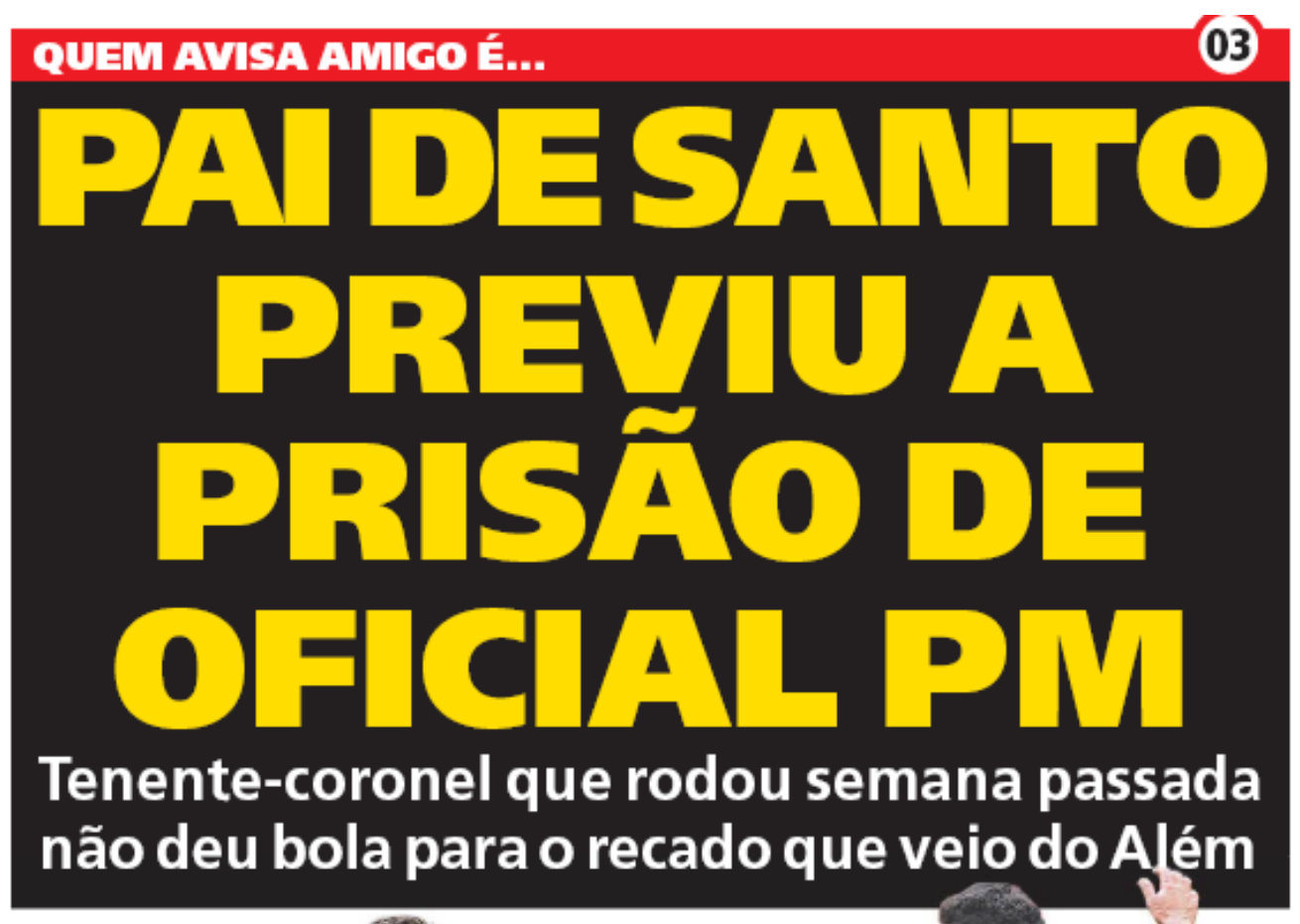

Ilustração 16 - Capa 331

\subsubsection{Frases triádicas}

As frases triádicas se baseiam na estrutura sintética da frase "Veni, vidi, vici” proferida por Julio César em 47 a.C. na guerra da Gália. Segundo Dias (1996, p.72), "as frases compostas com três segmentos verbais revelam a intertextualidade, no que o fenômeno linguístico tem de mais simples e acessível na memória do povo".

Observa-se, ainda, uma estrutura rítmica (2 sílabas e tônica na 1a $^{\text {}}$ sílaba). Na capa 19, há a construção da frase triádica em: "Banho, tosa e surra". 


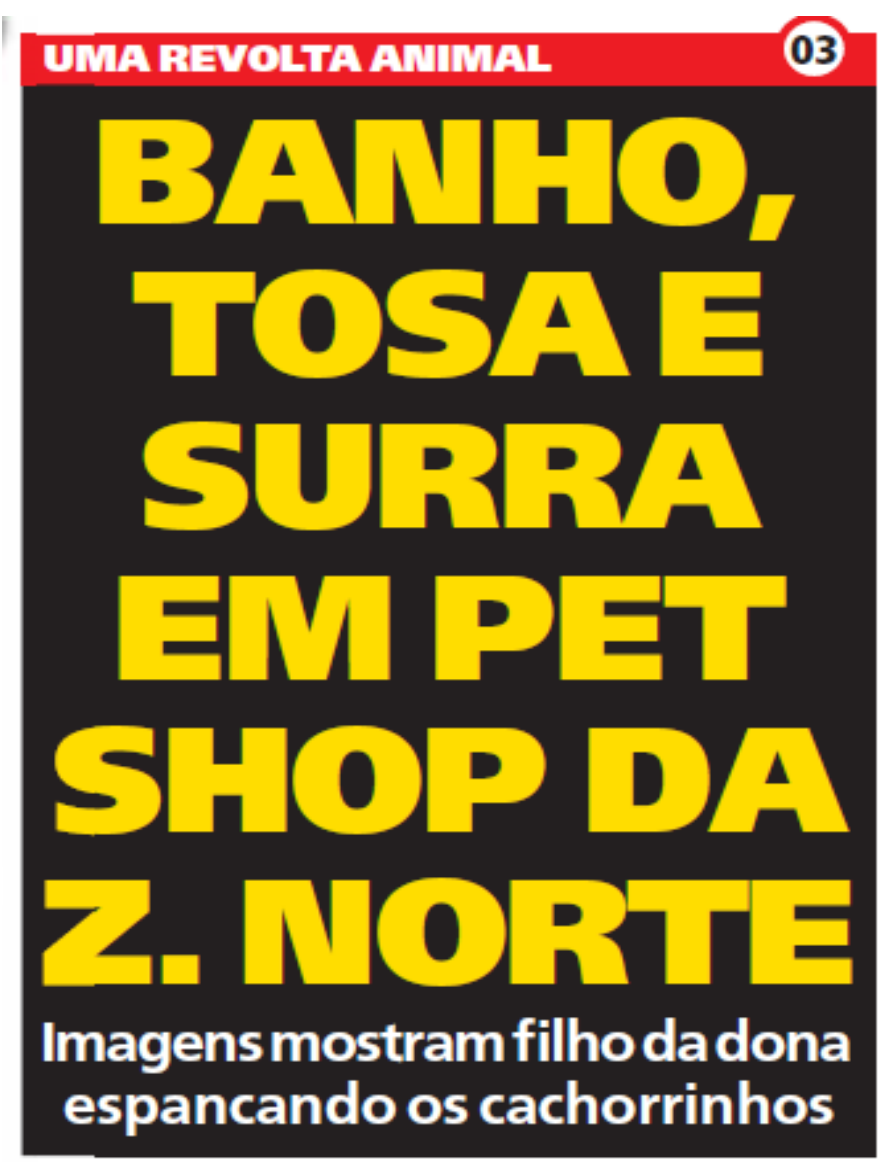

Ilustração 17 - Capa 19

\subsubsection{Envolvimento do narrador}

O envolvimento do narrador nos textos do jornal Meia Hora de Notícias é explícito. Ocorre repetidamente um posicionamento de quem escreve a notícia diante dos assuntos abordados, expressando seus comentários por meio uma linguagem coloquial. Essa "participação" do jornalista acontece principalmente graças a marcadores conversacionais.

Os marcadores conversacionais, segundo Charaudeau e Maingueneau (2008), representam uma série de elementos verbais e não-verbais, próprios de situações de interação e desempenham um papel de sinalização em relação à produção discursiva. Pertencentes a diversas categorias (interjeições, 
advérbios, conectores, adjetivos etc), os marcadores conversacionais são considerados característicos do discurso oral, sobretudo conversacional, e costumam ser os primeiros a serem eliminados na versão escrita de um diálogo. No caso da linguagem do jornalismo popular, justifica-se sua utilização em virtude da tentativa de aproximação com o discurso falado e com o leitor.

De acordo com Galembeck e Blanco (2001), os marcadores conversacionais de finais de turno como: né? não é? entendeu? exercem duas funções relacionadas com a troca de falantes: sugerem a entrega explícita do turno a outro interlocutor (passagem requerida) ou apenas sinalizam o fim do turno (passagem consentida).

O narrador se coloca explicitamente, utilizando a primeira pessoa, em algumas notícias, também com o intuito de mostrar envolvimento. E utiliza expressões para "falar" com o leitor, fazendo-lhe perguntas ou solicitando opiniões.

Na capa a seguir (capa 349) podemos observar o chapéu a expressão "Sabe na última?", típico da fala, introduz uma conversa entre os interlocutores.

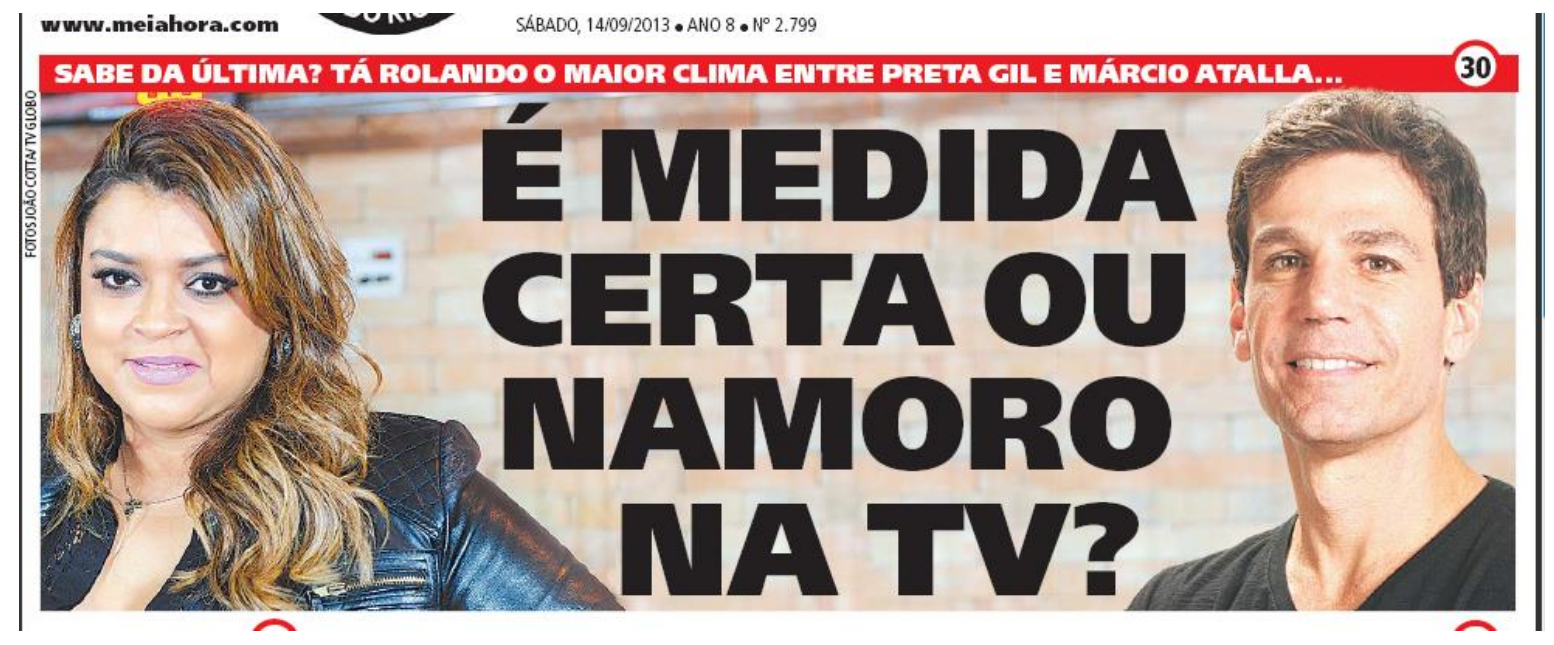

llustração 18 - Capa 349 


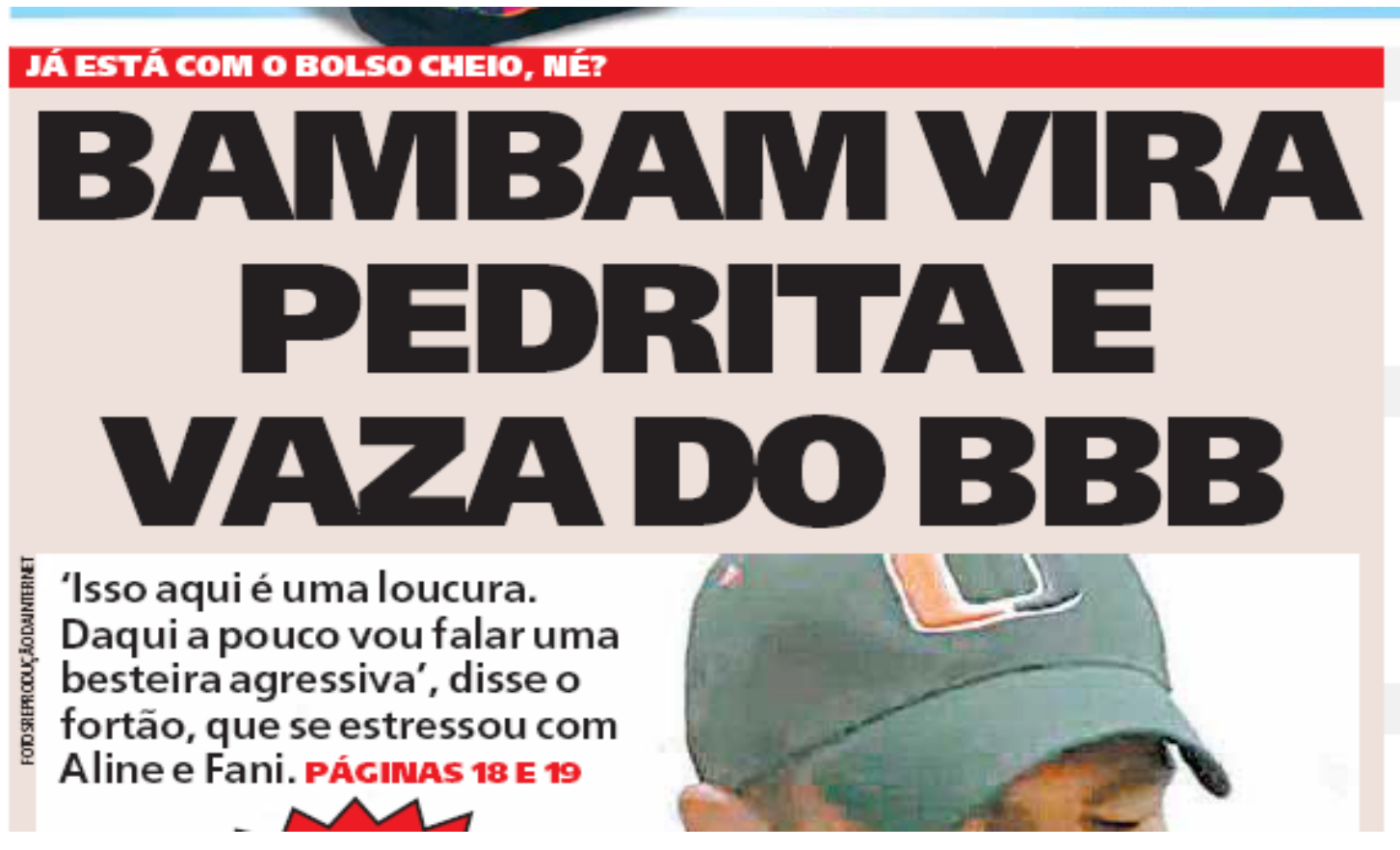

Ilustração 19 - Capa 105

No chapéu da capa 105 há o uso no marcador conversacional de final de turno "né?", o uso de tal marcador tem a intenção de se aproximar do leitor, simulando uma conversa entre jornal e leitor.

\subsection{Nível linguístico}

A linguística é dividida em áreas ou níveis estudados particularmente, como a fonética, a sintaxe, a morfologia e a lexicologia. Em nossa pesquisa a respeito dos recursos linguísticos utilizados pelo Meia Hora de Notícias, salientaremos como são empregados esses recursos, enquanto marcas de oralidade, tomando como base a intenção de aproximar o texto escrito do texto oral. 


\subsubsection{Fonética}

De acordo com Bechara (1999), a fonética é responsável pelo aspecto acústico e fisiológico dos sons reais e concretos dos atos linguísticos: a produção, a articulação e as variedades. Encontramos alguns recursos utilizados pelo jornal Meia Hora de Notícias para traduzir as características fonéticas da língua falada. Alguns deles tentam reproduzir o coro popular, muitas vezes por meio de onomatopeias e recursos de repetição, trazendo um efeito de comemoração ou de reivindicação ao texto, como nos exemplos abaixo.

Na capa 152 há a simulação de um coro em: "ÊE, Ê, Ê, tá com medinho da UPP!"
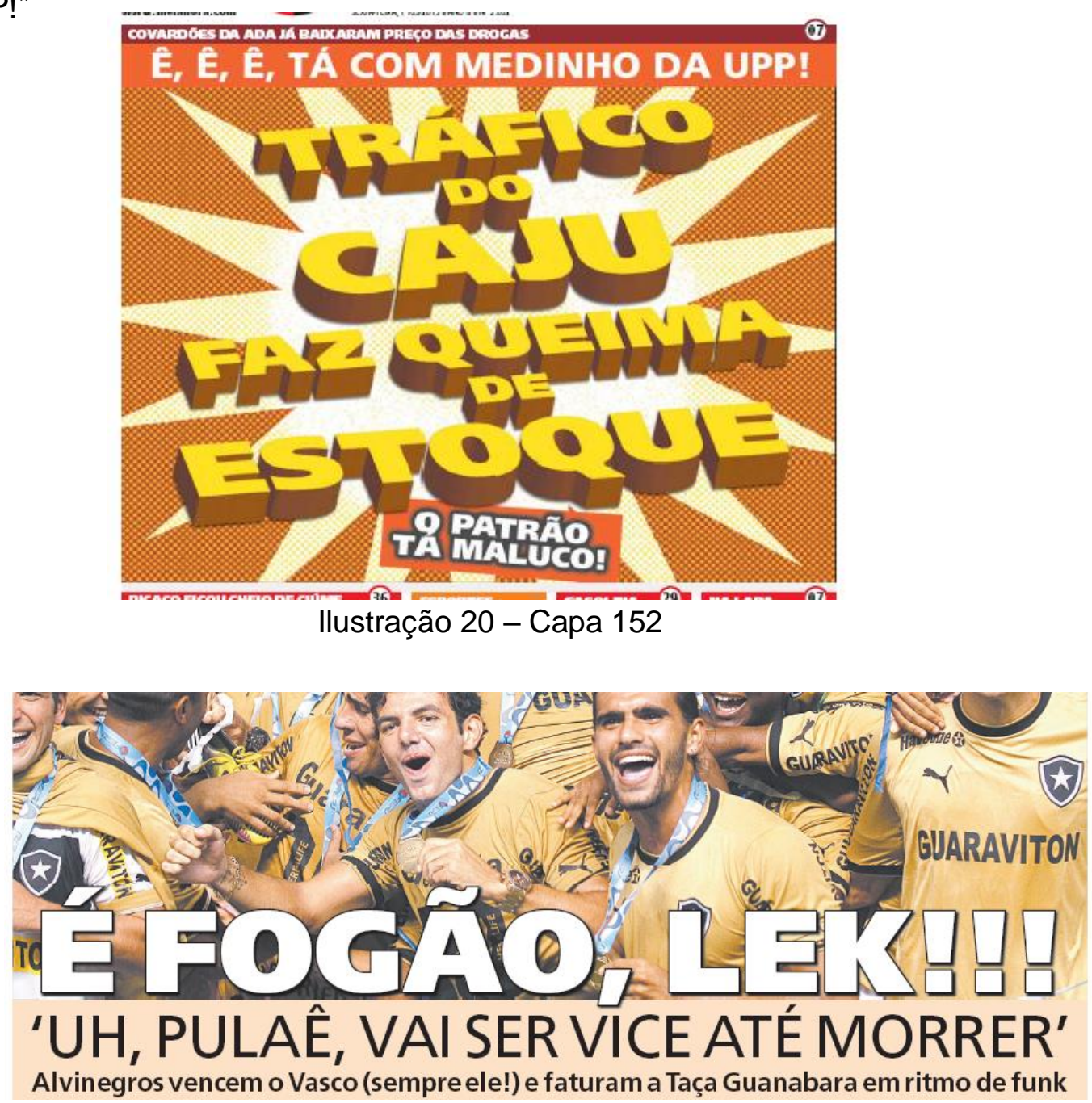

llustração 21 - Capa 162 


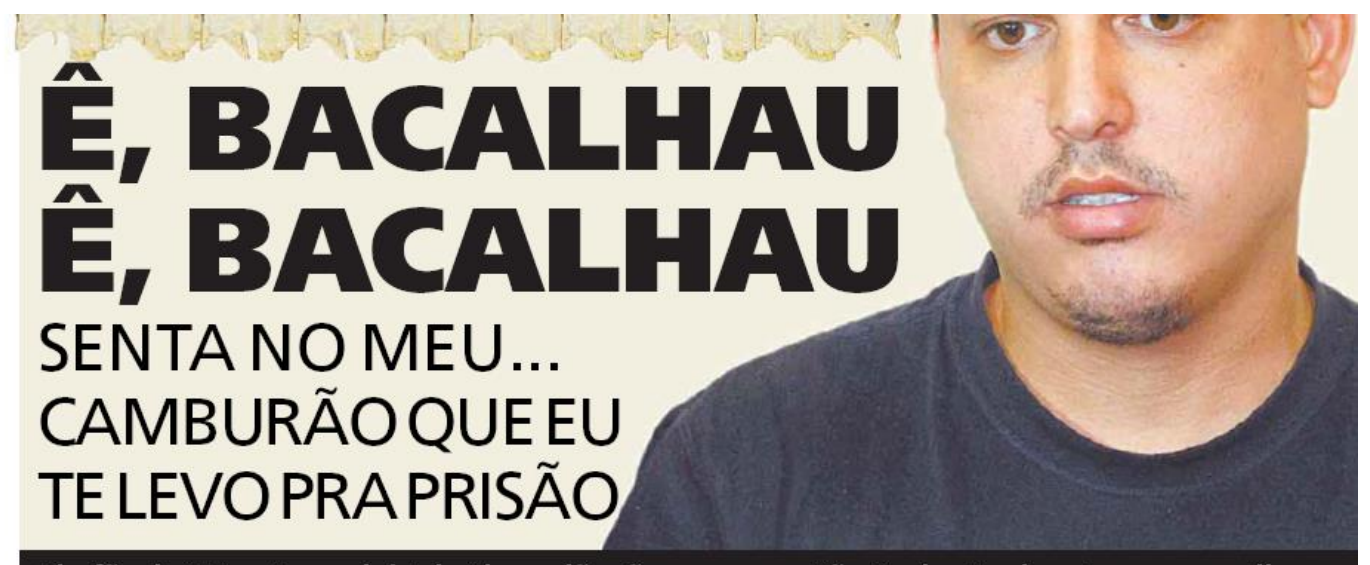

Chefão do CVe o 'zero-dois' do Chapadão são presos em SãoPaulo. Dupla estava com mulheres

\section{llustração 22 - Capa 2}

Notamos, ainda, que há um efeito de intertextualidade relacionado a esses efeitos fonéticos. São gritos de torcida utilizados em determinados contextos e reaproveitados pela linguagem do jornal para ressaltar o coro popular. No caso da capa 162, o jornal faz uso de um grito de torcidas rivais a do time mencionado, "Uh, pulaê, vai ser vice até morrer".

Outro efeito empregado pelo jornal é também recorrente na fala popular. São as formas reduzidas. Assim, temos a alteração de para em pra, para o em pro e está em tá. Como pode ser visto no título da manchete a seguir "Homem sem pênis já levou 100 mulheres pra cama"

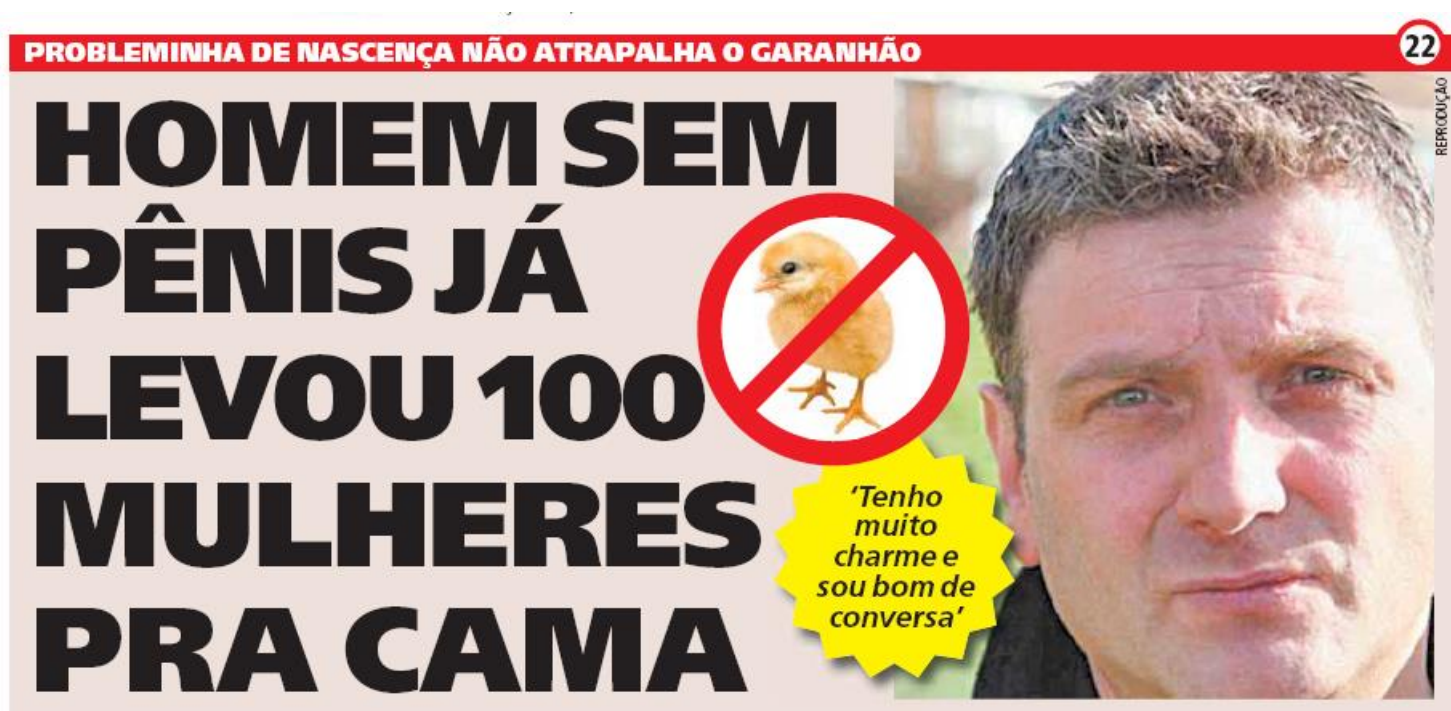

Segurança com 'algo a menos' vai ganhar um bilau feito com tecido do braço 


\subsubsection{Léxico}

Segundo Castilho (2010, p.110), “o léxico é um inventário de categorias e subcategorias cognitivas; e de traços semânticos inerentes". Para o autor, esse inventário é virtual, pré-verbal, um feixe de propriedades de que lançamos mão para a criação das palavras.

No Meia Hora de Notícias, a variação linguística se concentra mais no campo lexical, em virtude das gírias e expressões populares utilizadas em seus textos. Segundo Gurgel (1990), a gíria é o componente mais importante dentre as variações mais repetidas no sistema linguístico, pois possui o maior número de palavras e blocos, frases, expressões ou alocuções para a linguagem usual e o equipamento falado. Preti (1983) salienta que, em sua essência, a gíria constitui-se num vocabulário ligado à vida e à cultura de um grupo social restrito. Ela tem a função de defesa e preservação de classe, todavia, como muito frequência se vulgariza e passa a uma gíria geral. Dentre as amostras estudadas, encontramos uma gama de itens lexicais que representam a fala do povo.

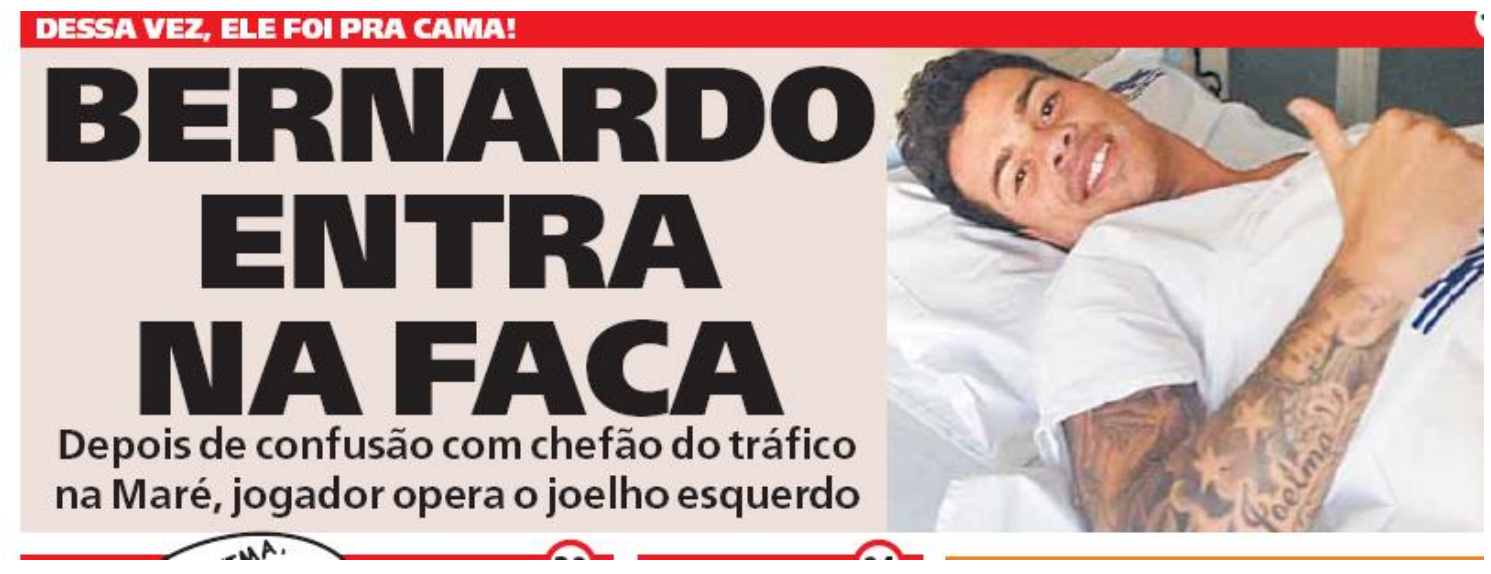

llustração 24 - Capa 214 
No caso, "entrar na faca" é expressão que significa passar por procedimento cirúrgico, cuja origem é uma gíria ou jargão médico, mas já se tornou comum entre a as expressões populares utilizadas em jornais.

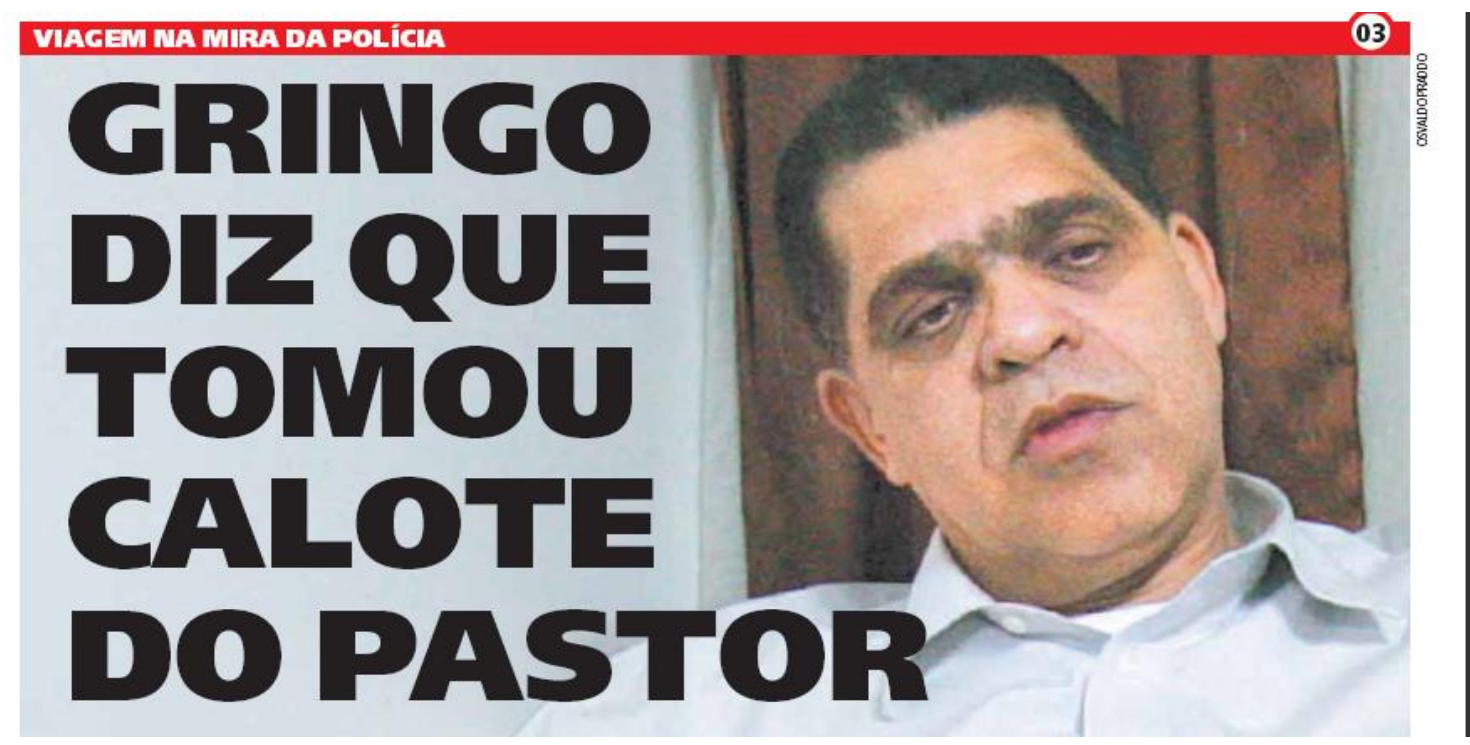

llustração 25 - Capa 225

"Gringo", também é outra expressão popular das mais usadas na oralidade. É usada para se referir aos estrangeiros de modo geral.

Análises semelhantes podem ser aplicadas nas ocorrências que seguem a seguir.

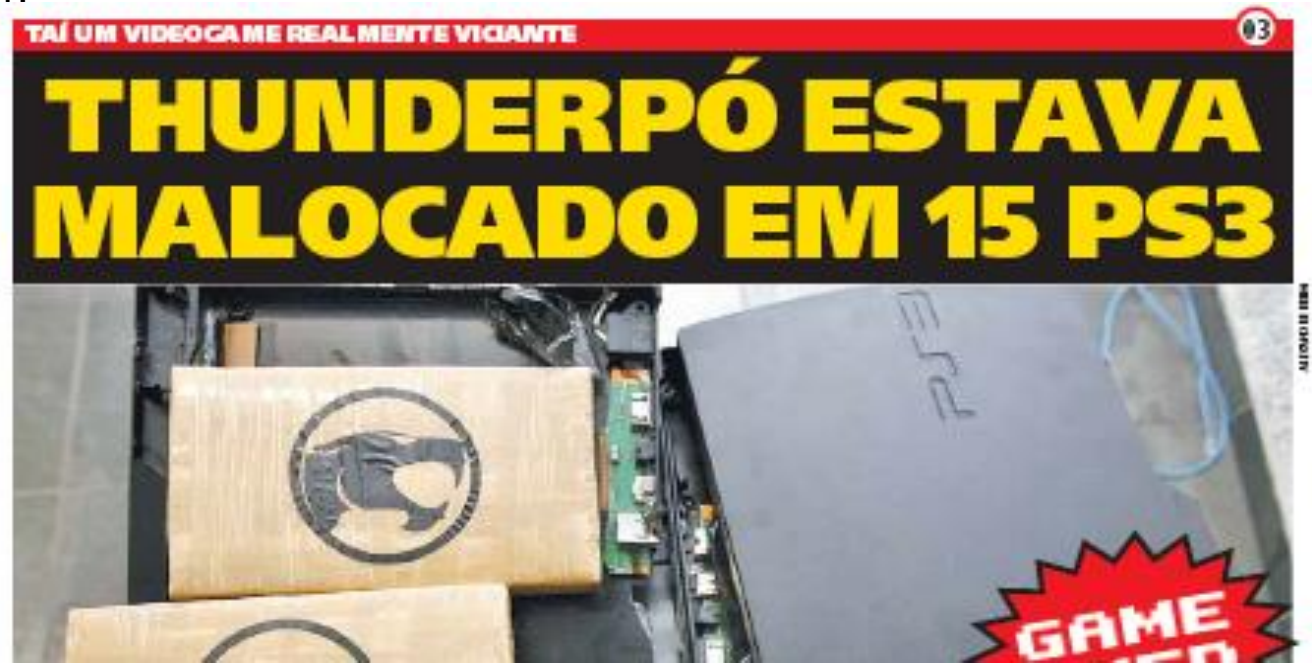

llustração 26 - Capa 9

"Malocado" gíria para algo bem escondido. 


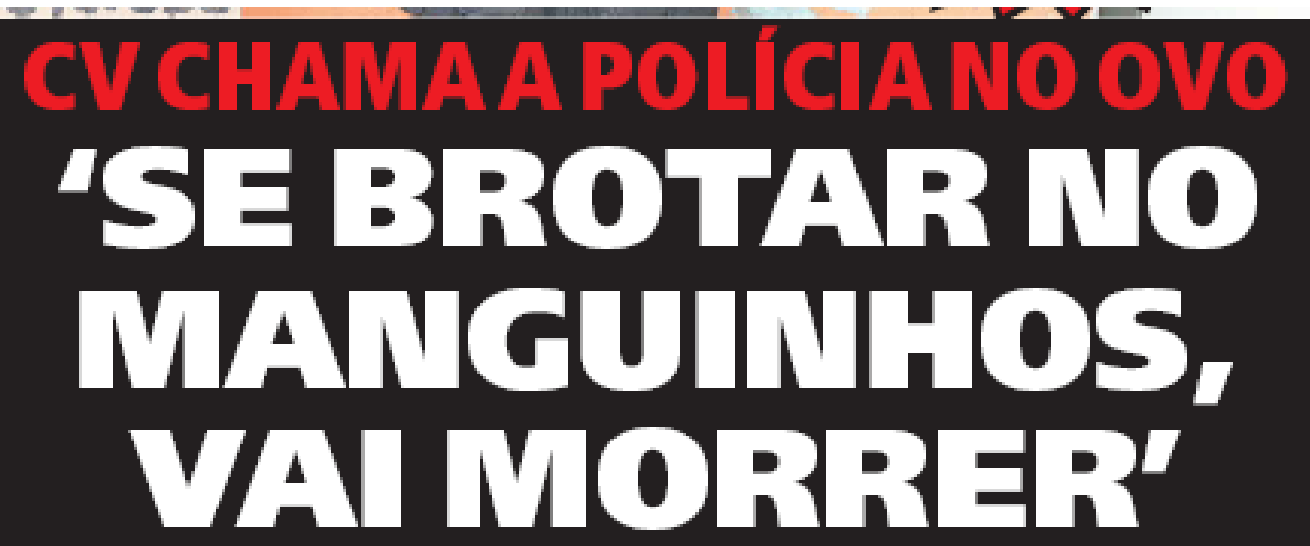

Montagemno Youtube desafia ocupação marcada pra domingo e diz que traficantes do Jacaré e do Mandela também vão pro pau. Será? Duvideodól pAcamas os Eo4

Ilustração 27 - Capa 12

A gíria "brotar" no sentido de aparecer em algum lugar.

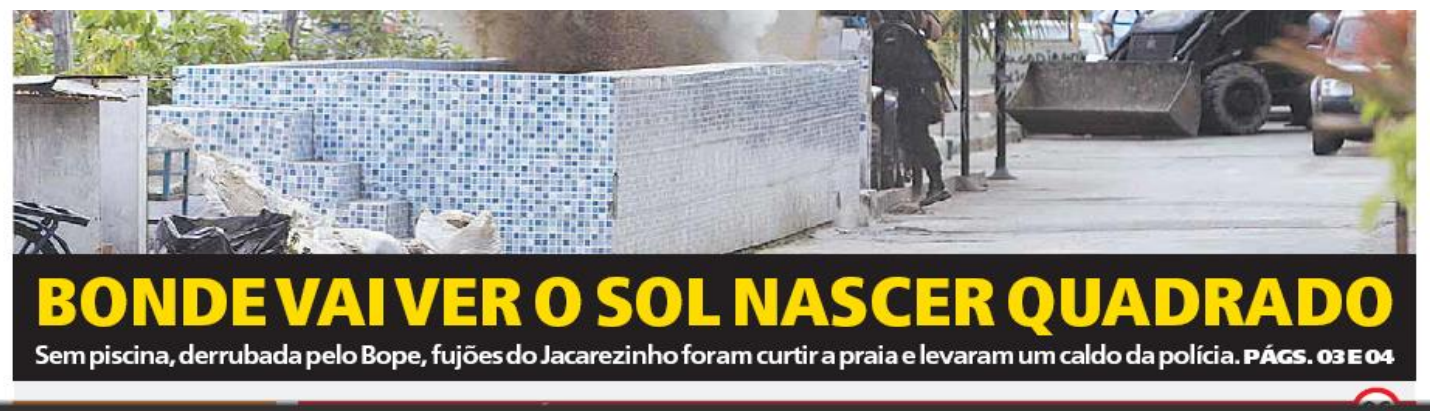

Ilustração 28 - Capa 17

"Bonde" como gíria para quadrilha, bandidos.

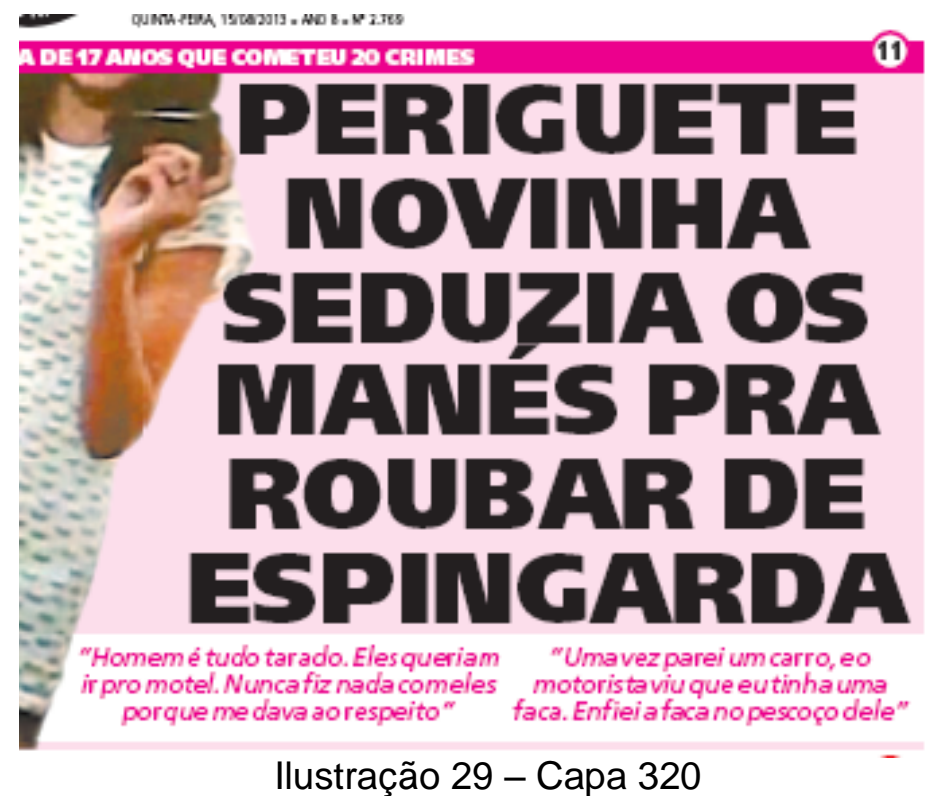

llustração 29 - Capa 320 
$\mathrm{Na}$ capa 320 observamos as gírias: "periguete" (mulher sedutora) e "novinha" (Garota com menos de 18 anos)

\subsubsection{Sintático}

A sintaxe é a parte da linguística responsável pelo estudo da função das palavras na frase e das frases no discurso. Embora o jornal valorize os aspectos da oralidade, seu discurso é heterogêneo, já que transita entre a linguagem popular e a linguagem culta. Por se tratar de um texto jornalístico escrito, e não uma transcrição da fala popular, há um apego às regras sintáticas. Associado a isso, existe o fato de que o jornalista que escreve tais textos não faz parte da mesma classe social de seu público alvo, portanto, há um planejamento dessa linguagem.

Observamos, no entanto, alguns aspectos a serem notados. Como por exemplo, o uso do verbo ter com sentido de existir. Na norma culta, essa construção é considerada inadequada, mas é bastante utilizada na fala popular:

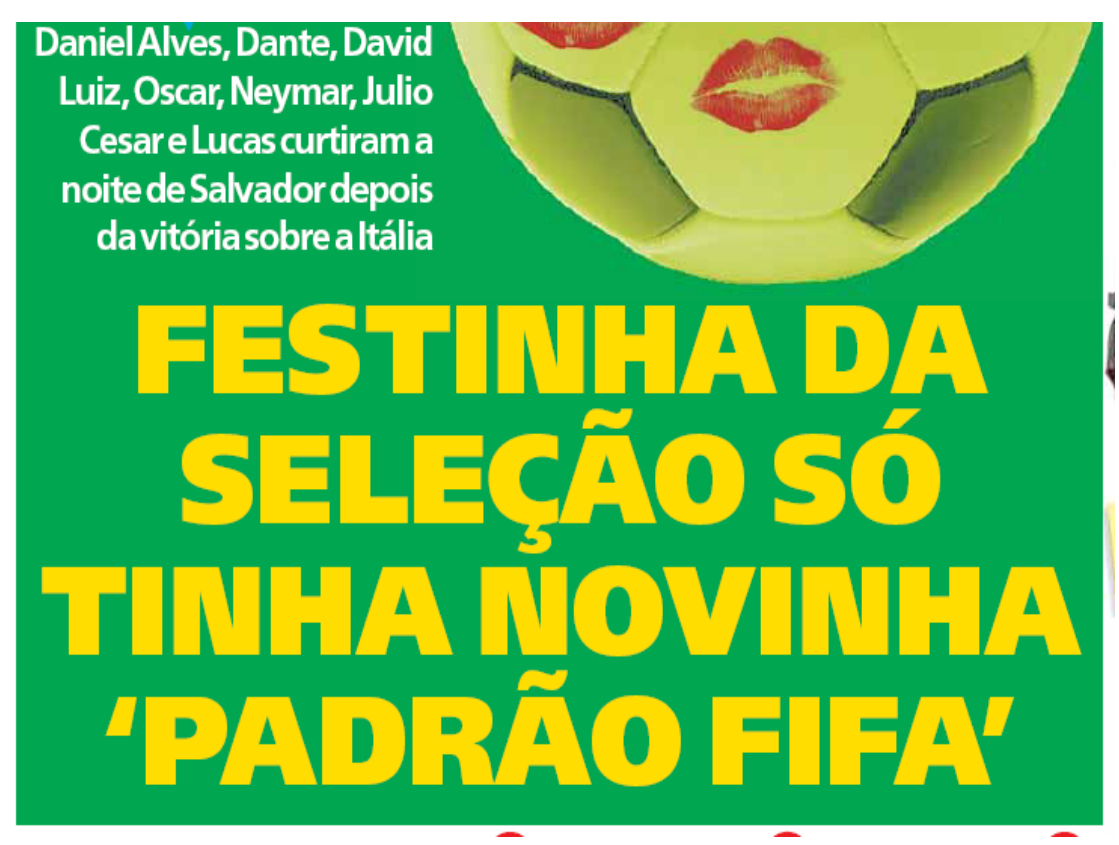

llustração 30 - Capa 268 


\subsubsection{Morfológico}

Na morfologia, estuda-se a composição, a concepção e a classificação das palavras. Esse estudo é voltado para as palavras isoladamente, sem levar em conta sua participação na frase ou período. As marcas de âmbito morfológico no Meia Hora de Notícias dizem respeito, sobretudo, à terminação dos vocábulos no aumentativo e diminutivo

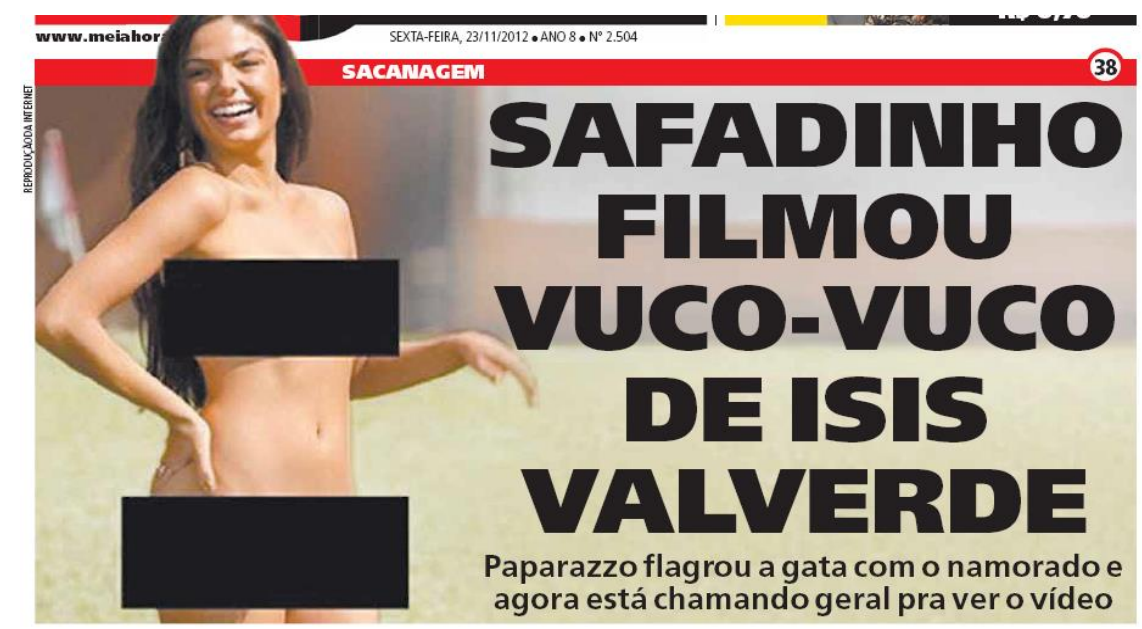

Ilustração 31 - Capa 54

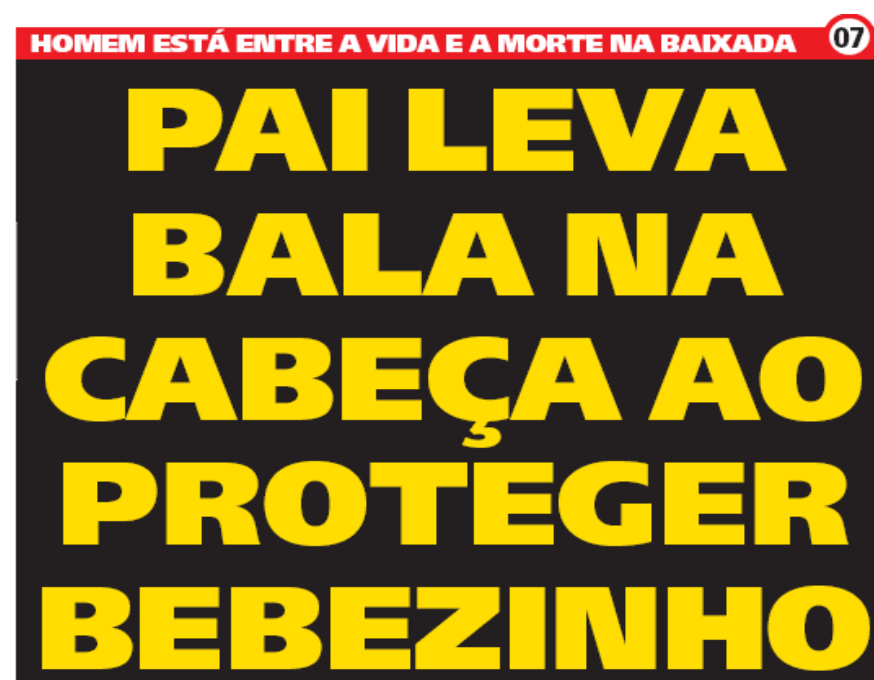

Professor pegou o filho de 9meses no coloprafugir de tiros dados por traficantes. A criança nada sofreu

Ilustração 32 - Capa 260 
Também é possível notar o emprego de um sufixo popular (ada) para formar o coletivo de uma palavra, numa criação analógica: mulherada. Isso ocorre no exemplo da capa 60, 161 e 272.

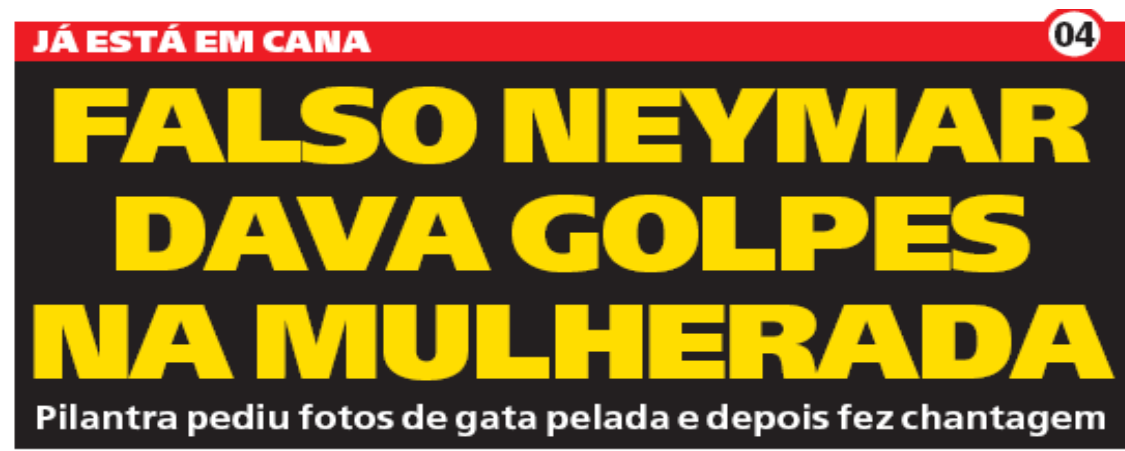

Ilustração 33 - Capa 60

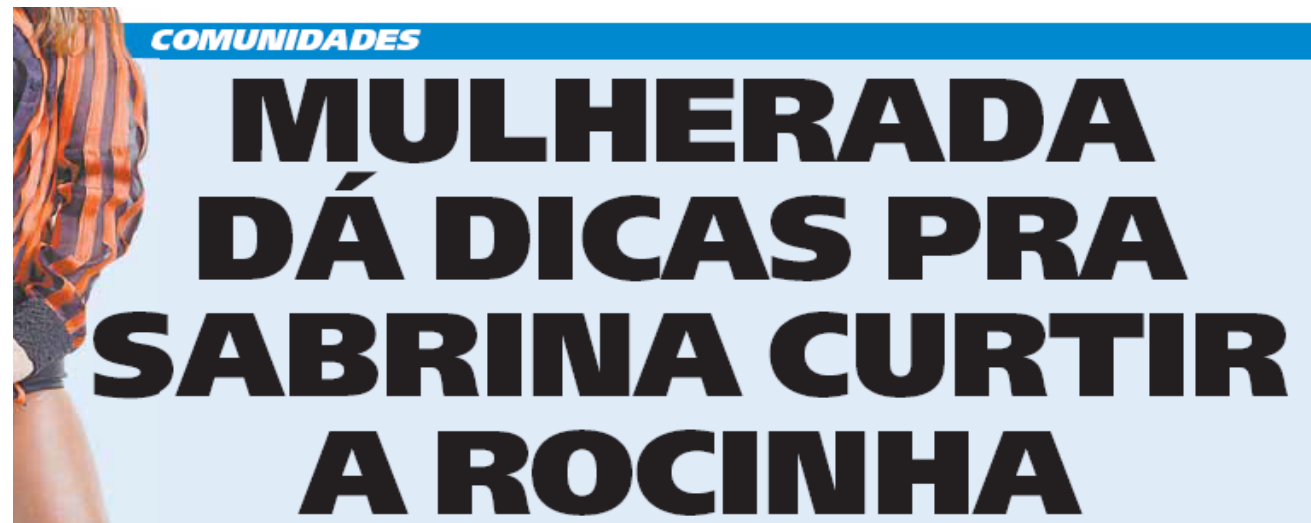

Locais mostram à japa, que vai morar uns dias na comunidade, onde cortar o cabelo, comprar roupa, comer, malhar e fazer a night $\frown$ Ilustração 34 - Capa 161

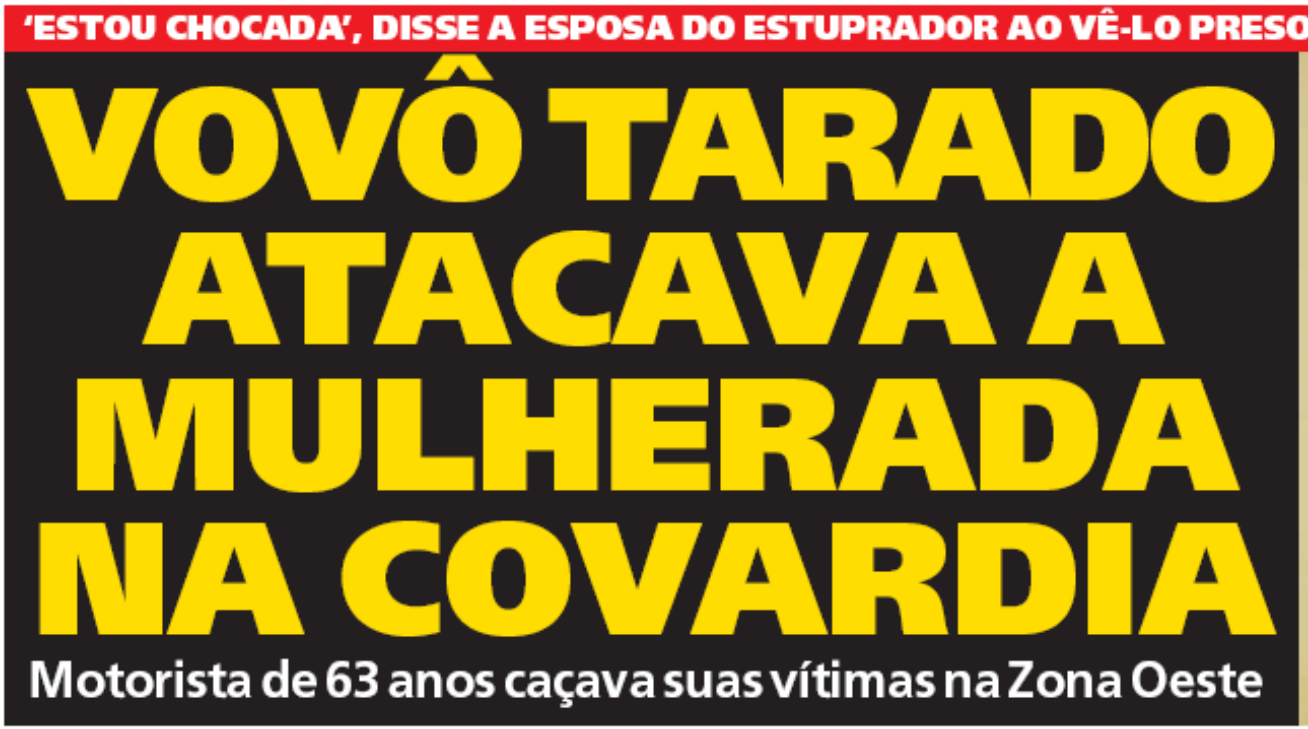

Ilustração 35 - Capa 272 
A simplificação é comum na língua oral popular. A presença dessas marcas no texto do jornal mostra a ligação do discurso escrito com a oralidade. Segundo Dias (1996, p.79), "de certa forma, o jornal contribui para a divulgação dessas criações linguísticas do povo, conservando-as ou acompanhando seu processo de renovação".

A partir dessas amostras, verificamos que o jornalista tenta explorar 0 universo do leitor, utilizando um vocabulário rico em gírias e expressões populares que permite uma identificação com o público-alvo. 


\section{CONCLUSÕES}

Em nossa pesquisa consideramos que o jornalismo popular procura se aproximar ao máximo da fala popular por meio da linguagem da qual se utiliza em suas capas. Nosso estudo procurou mostrar as características desse tipo de texto jornalístico, utilizando como corpus da pesquisa o jornal Meia Hora de Notícias e os fundamentos teóricos de: Marcuschi (1993, 1995, 2004 e 2007), Koch e Oesterreicher $(1985,2007)$, Charaudeau $(2007,2008)$, Koch (1997, 2008), Ong (1998), Preti (1983, 2004), Dias (1996), Urbano (1998, 2000, 2006 e 2011), Fávero (2009). Consideramos que a linguagem desse jornal está próxima da linguagem falada ao verificarmos que as semelhanças e diferenças entre os textos orais e escritos estão inseridas em um continuum. Assim, o texto do jornal popular tem características mistas, como o fator envolvimento, que é típico da língua falada e o fator integração, da língua escrita.

Podemos crer que essas marcas de oralidade nas capas do jornal são planejadas pelo editor coma intenção de atingir o leitor de culturas diversas, que teve pouco acesso aos estudos e utiliza uma tipologia de linguagem usual como forma de expressão, levantamos a hipótese de que há uma simulação de oralidade no jornalismo popular. Assim, utilizam-se estratégias discursivas e até ideológicas para que ocorra uma identificação maior desses leitores com a fala popular. Essa simulação acontece principalmente porque o sujeito que escreve as notícias não faz parte do mesmo meio social de seu público-alvo e, portanto, constrói simulacros do próprio jornal e do leitor.

Para fundamentar nossa hipótese, selecionamos e analisamos amostras de 30 manchetes do jornal Meia Hora de Notícias dentro do período analisado 
de 1 ano, tabulamos 365 capas do referido jornal, analisando a temática da qual tratavam. Optamos pela análise de manchetes (que classificamos, aqui, como a junção de chapéu, títulos e linha fina) por acreditarmos, segundo mostram os estudos, que há uma maior presença de marcas da oralidade nesses gêneros, já que eles funcionam como atrativos para o leitor.

Ao analisarmos as características de tais textos e os recursos empregados com base em dois níveis, discursivo e linguístico, pudemos confirmar nossa hipótese de que, de fato, há uma simulação de oralidade no jornal, visto que:

a) o editor que escreve para o jornal idealiza um público-alvo que pode ou não se identificar com o discurso. Sendo assim, ele constrói um discurso baseado na imagem que ele tem do outro.

b) a linguagem do jornal não pode ser completamente baseada nos recursos da oralidade, pois a fala não poderia ser reproduzida em sua totalidade. Desse modo, ao preparar as notícias, o editor se preocupa com a língua culta, com a sintaxe escrita. Assim, ocorre frequentemente um contraste entre a linguagem das manchetes, carregada de recursos da oralidade, e a linguagem das notícias, presa à sua sintaxe.

c) Os textos orais e escritos se enquadram no conceito de continuum, no qual há uma relação de proximidade e diferença entre os diversos gêneros textuais. Assim, é aceitável que no texto de um jornal popular surjam recursos que se aproximam da oralidade, uma vez que nesse tipo de discurso há traços em comum com a conversação espontânea. 
Nossa pesquisa buscou avaliar um tipo de jornalismo consumido pelas classes populares, por um público leitor, em sua maioria, pouco escolarizado. O jornalismo popular tem assumido uma maior importância social, já que informa setores mais amplos da população e não está limitado a um único estilo de se fazer notícia. $O$ jornal propõe uma relação com o leitor, não somente por meio das ocorrências da oralidade, que comprovamos existir. $O$ jornal Meia Hora de Notícias constrói uma relação com o seu público; tal relação está longe de ser passiva, uma vez que o jornal faz sucesso porque há uma recompensa aos leitores, sejam elas por causa do entretenimento oferecido ou pelo baixo preço. Isso ocorre, principalmente, porque o jornalismo popular se pauta pelo interesse do público e não pelo interesse público, dando ênfase às temáticas de interesse da classe $\mathrm{C}$, seu principal público consumidor.

Podemos concluir que há a presença de marcas de oralidade em todas as 365 capa que pudemos analisar, há ainda o uso de várias outras estratégias cuja intenção é a aproximação com o leitor, podemos destacar o uso do humor. Pretendemos continuar nossos trabalhos comprovando tal hipótese do uso da oralidade e, também, do humor como estratégia de aproximação. 


\section{REFERÊNCIAS BIBLIOGRÁFICAS}

\section{REFERÊNCIAS}

AMARAL, Márcia Franz. Imprensa popular: sinônimo de jornalismo popular? Anais do XXIX Congresso Brasileiro de Ciências da Comunicação, 6 a 9 de set. 2006. Brasília: Universidade de Brasília, 2006.

BAKHTIN, M. Estética da criação verbal. Os gêneros do discurso. $2^{\mathrm{a}}$ ed. São Paulo: Martins Fontes, 1997. . Estética da Criação Verbal. São Paulo: Martins Fontes, 2000.

BECHARA, Evanildo. Moderna Gramática Portuguesa. Rio de Janeiro: Lucerna, 1999.

BONINI, A. O conhecimento de jornalistas sobre gêneros textuais: uma contribuição à teoria dos esquemas cognitivos para textos. Florianópolis, 1999. Tese (Doutorado em Linguística) - Curso de Pós Graduação em Letras/Linguística, Universidade Federal de Santa Catarina.

CARVALHO, Nelly. Publicidade: a linguagem da sedução. São Paulo: Ática, 1996.

CASTILHO, A. T. Nova gramática do português brasileiro. São Paulo: Contexto, 2010. 
CHARAUDEAU, Patrick. Discurso das mídias. Tradução Ângela M. S. Corrêa. São Paulo: Contexto, 2006.

. Linguagem e discurso - modos de organização. Tradução Ângela M.

S. Corrêa, Ida Lúcia Machado. São Paulo: Contexto, 2008.

; MAINGUENEAU, Dominique. Dicionário de análise do discurso. 2. ed. Tradução Fabiana Komesu. São Paulo: Contexto, 2008.

DANGER, E.P. A cor na comunicação. Trad. De llza Marques de Sá, 1ł ed. Brasileira, Rio de Janeiro, Forum Editora, 1973.

DIAS, Ana Rosa Ferreira. $\mathbf{O}$ discurso da violência - as marcas da oralidade no jornalismo popular. São Paulo: Cortez, 1996.

DUARTE, Ricardo; LANNES, Joaquim; et al. A estratégia das imagens e dos títulos nas capas do tablóide Meia Hora de Notícias do Rio de Janeiro: o jogo dos valores instituídos. I Colóquio em Comunicação e Sociabilidade "Comunicação Midiática: Instituições, Valores e Cultura". Belo Horizonte, novembro de 2008.2 Disponível em: $<$ http://www.fafich.ufmg.br/cis/pdfs/grispress/DUARTE_ricardo.pdf >. Acessado em 11 de jun. 2010.

FÁVERO, Leonor ET AL. Oralidade e escrita - perspectivas para o ensino da língua materna. 7. ed. São Paulo: Cortez, 2009. 
FLAUZINO, Valdenir. Classe C, o público de $\mathbf{R} \$ \mathbf{4 1 0}$ bilhões. Disponível em http://www.webinsider.com.br. Publicado em 03 de junho de 2008. Acesso em 02 de junho de 2014.

FOLHA DE S. PAULO, Manual da redação. 14. ed. São Paulo: Publifolha, 2010.

GALEMBECK, BLANCO. Marcadores conversacionais na linguagem jornalística. Disponível em: $\quad<$ http://www.filologia.org.br/revista/arti go/7\%2820\%2905.htm>. Publicado em 2001. Acesso em 03 de junho de 2014.

GONTIJO, Silvana. O livro de ouro da comunicação. Rio de Janeiro: Ediouro, 2004.

GURGEL, J.B. Serra e. Dicionário de gíria - Modismo linguístico - O equipamento falado do brasileiro. Rio de Janeiro:Gráfica MEC Editora, 1990.

HALLIDAY, M.A.K.; HASAN, R. Cohesion in English. London: Longman, 1976.

HALLIDAY, M.A.K. Introduction to functional grammar. Londres: E. Arnold. 1985. On Grammar. Collected Works of M. A. K. Halliday (vol. 1), ed. By Jonathan Webster. London:Continuum: 2002, 323-351. 
$\mathrm{KOCH}$, Ingedore G.V. Interferência da Oralidade na Aquisição da Escrita. In: Trabalhos em Linguística Aplicada. Campinas, (30.): 31-38, Jul./Dez. 1997.

Ler e compreender: os sentidos do texto. $2^{\mathrm{a}}$ ed., $2^{\mathrm{a}}$ reimpressão. São Paulo: Contexto, 2008.

$\mathrm{KOCH}$, Peter; OESTERREICHER, Wulf. Sprache der Nähe - Sprache der Distanz. Mündlichkeit und Schriftlichkeit im Spannungsfeld von Sprachtheorie und Sprachgeschichte. In: Romanistisches Jahrbuch, 36. Berlim; Nova lorque: Walter de Gruyter, 1985, p. 15-43.

. Lengua hablada en la Romania. Español, Francés, Italiano (Biblioteca Románica Hispánica. Estudios y Ensaios; 448). Madrid: Gredos, 2007.

LAGE, Nilson. Ideologia e técnica da notícia. 3. ed. Florianópolis: Insular, Ed. da UFSC, 2001. . Linguagem jornalística. 7. ed. São Paulo: Ática, 2001b.

LEVINSON, Stephen. Pragmatics. Cambridge: Cambridge University Press, 1983.

LUSTOSA, Elcias. O texto da notícia. Brasília: UnB, 1996. 
MAINGUENEAU, D. Interdiscurso. In: CHARAUDEAU, P. \& MAINGUENEAU, D. (Orgs.) Dicionário de Análise do Discurso. Coord. da trad.: Fabiana Komesu. São Paulo: Contexto, 2004.

MARCUSCHI, Luiz Antônio. Análise da conversação. São Paulo: Ática, 1986. O tratamento da oralidade no ensino de língua. Recife, Universidade Federal de Pernambuco, texto mimeografado. 1993 . Oralidade e Escrita. Conferência apresentada no II COLÓQUIO FRANCO-BRASILEIROS SOBRE LINGUAGEM E EDUCAÇÃO, na Universidade federal do Rio Grande do Norte (UFRN), Natal, 26-28 de Junho de 1995.

. Da Fala para a Escrita: Atividades de Retextualização.

São Paulo: Cortez, 2001.

. Gêneros textuais e ensino. 3 ed. Rio de Janeiro: Lucerna , 2005

.MARCUSCHI, Luiz Antônio. Gêneros Textuais: configuração, dinamicidade e circulação. In KARWOSKI, Acir Mário.; GAYDECZKA, Beatriz; BRITO, Karim Siebeneicher. Orgs. Gêneros textuais reflexões e ensino. 2 ed. Rio de Janeiro: Lucerna, 2006.

. Da fala para a escrita - atividades de retextualização. 8 . ed. São Paulo: Cortez, 2007. . Produção textual, análise de gêneros e compreensão. São 
Paulo: Parábola Editorial, 2008.

MELO, José Marques de. Jornalismo opinativo: gêneros opinativos no jornalismo brasileiro. Campos do Jordão: Mantiqueira, 2003.

MESTRINER, Fábio. Design de embalagem. Curso Avançado. 1ł. ed. São Paulo: Prentice Hall, 2002.

MICHAUD, Y. A violência. São Paulo: Ática, 1989.

MOHERDAUI, L. Em busca de um modelo de composição para os jornais digitais. In: Anais do II Simpósio Nacional da ABCiber (Associação Brasileira de Pesquisadores em Cibercultura). São Paulo - SP, 2008.

NÓBREGA, Marlene Assunção. Quando os provérbios dão a manchete: a oralidade no texto escrito jornalístico - o caso Jornal da Tarde. São Paulo, 2008. Tese (Doutorado em Letras) - Curso de Pós Graduação em Letras, Universidade de São Paulo.

ONG, W. J. Oralidade e cultura escrita: a tecnologização da palavra. Campinas: Papirus, 1998. 
PENA, Felipe. Teoria do Jornalismo. São Paulo: Contexto, 2008.

PRETI, D. A linguagem proibida: um estudo sobre a linguagem erótica. São Paulo: T.A. Queiroz, 1983.

A linguagem proibida - um estudo sobre a linguagem erótica. São Paulo: t. A. Queiroz, 2004.

SCHUDSON, Michael. Discovering the News: A social history of American newspapers. 1978. New York: Basic Books. 240 p.

SODRÉ, Muniz. A comunicação do grotesco. 10. ed.Petropolis: Vozes, 1985. . Muniz; PAIVA, Raquel. O império do grotesco. Rio de Janeiro, Mauad, 2002.

SOUSA, Jorge Pedro. Uma história breve do jornalismo no Ocidente. 2008.

Universidade Fernando Pessoa. Disponível em: http://www.bocc.ubi.pt/pag/sousa-jorge-pedro-uma-historia-breve-dojornalismo-no-ocidente.pdf. Acesso em: 20 junho de 2014.

TAKAZAKI, Heloísa Harue. Língua Portuguesa. São Paulo: Ibep, 2004. 360 p.

TRAQUINA, Nelson. O que é o Jornalismo. Lisboa: Quimera, 2007 
TRAVASSOS, Tarcisia. A transformação histórica do gênero capa de jornal. 2010. 179 f. Tese (Doutorado em Letras) - Universidade Federal de Pernambuco, Pernambuco, 2010.

URBANO, Hudinilson. Variedades de planejamento no texto falado e no escrito. In: PRETI, Dino (Org.). Estudos de língua falada: variações e confrontos. São Paulo: Humanitas/ FFLCH/ USP, 1998. p. 131-151.

Oralidade na literatura ( 0 caso Rubem Fonseca).

São Paulo: Cortez, 2000.

. Usos da linguagem verbal. In: PRETI, D. Oralidade em diferentes discursos. São Paulo: Humanitas, 2006.

A frase na boca do povo. São Paulo: Contexto, 2011.

VAL, M. G. C. Redação e textualidade. 3. ed. São Paulo: Martins Fontes, 2006.

VERÓN, Eliseo. Fragmentos de um tecido. Rio Grande do Sul: Unisinos, 2005.

WOLF, Mauro. Teorias da comunicação. Lisboa: Presença, 1995. 


\section{ANEXOS}

\begin{tabular}{|c|c|c|}
\hline \multicolumn{3}{|r|}{ TABULAÇÃO CAPAS DOS JORNAIS MEIA HORA DE NOTÍCIAS - 01/10/2012 A 30/09/2013 } \\
\hline № & DATA & MANCHETE \\
\hline & & OUTUBRO \\
\hline 1 & 01/10/2012 & HEBE, EU TE AMO \\
\hline 2 & $02 / 10 / 2012$ & Ê BACALHAU. Ê BACALHAU. SENTA NO MEU... CAMBURÃO QUE EU TE LEVO PRA PRISÃO \\
\hline 3 & $03 / 10 / 2012$ & TÁ ACHANDO A BMW RUIM, FRED? ENTÃO ENCARA UM BUSÃO, PÔ! \\
\hline 4 & $04 / 10 / 2012$ & CHEFÃO DO PÓ ESCULHACHA ADRIANO: “O IMPERADOR É MALUCO” \\
\hline 5 & $05 / 10 / 2012$ & FRED JÁ PREPARA A CASCA DE BANANA PRA DERRUBAR O FOGÃO \\
\hline 6 & $06 / 10 / 2012$ & INTERNADA ÀS PRESSAS \\
\hline 7 & $07 / 10 / 2012$ & \\
\hline 8 & $08 / 10 / 2012$ & MESÁRIO DOIDÃO FUMA MACONHA E SE DÁ MAL \\
\hline 9 & 09/10/2012 & THUNDERPÓ ESTAVA MALOCADO EM 15 PS3 \\
\hline 10 & $10 / 10 / 2012$ & VUCO-VUCO NA PRAIA DO LEME DÁ CADEIA \\
\hline 11 & $11 / 10 / 2012$ & MARIDO DE ATRIZ DA TV GLOBO É VISTO AOS BEIJOS COM RAPAZ \\
\hline 12 & $12 / 10 / 2012$ & CV CHAMA A POLÍCIA NO OVO 'SE BROTAR NO MANGUINHOS, VAI MORRER' \\
\hline 13 & $13 / 10 / 2012$ & TIROTEIO EM PULA-PULA DE SHOPPING NA VILA DA PENHA DEIXA DOIS FERIDOS \\
\hline 14 & $14 / 10 / 2012$ & OPERAÇÃO DO BOPE NO JURAMENTO MANDA 5 PRA VALA \\
\hline 15 & $15 / 10 / 2012$ & CORRE, VAGABUNDO! \\
\hline 16 & $16 / 10 / 2012$ & POLÍCIA SUFOCA FAVELAS DO CV PRA ACHAR FUJOES DE MANGUINHOS \\
\hline 17 & $17 / 10 / 2012$ & BONDE VAI VER O SOL NASCER QUADRADO \\
\hline 18 & $18 / 10 / 2012$ & PROMETEU CURA PRO CÂNCER EM TROCA DE SEXO: PRESO PASTOR QUE ESTUPROU MENINA \\
\hline
\end{tabular}




\begin{tabular}{|c|c|c|}
\hline 19 & 19/10/2012 & BANHO, TOSA E SURRA EM PET SHOP DA Z. NORTE \\
\hline 20 & $20 / 10 / 2012$ & HOMEM ENTERRA AMANTE VIVA NO QUINTAL DE CASA \\
\hline 21 & $21 / 10 / 2012$ & VIGÁRIO TAMBÉM TEM SUA CHUPETINHA \\
\hline 22 & $22 / 10 / 2012$ & COVARDÃO DO MMA FINALIZA A NAMORADA COM MATA-LEÃO \\
\hline 23 & $23 / 10 / 2012$ & VIAGEM FATAL \\
\hline 24 & $24 / 10 / 2012$ & MUITO DOIDO DÁ AS CARAS NO PRÓPRIO VELÓRIO \\
\hline 25 & $25 / 10 / 2012$ & JAPONÊS DÁ 1,5 MILHÃO PRA TIRAR SELINHO DE BRASILEIRA \\
\hline 26 & $26 / 10 / 2012$ & MENOR É MORTO POR OUVIR FUNK ALTO EM BUSÃO NA BAIXADA \\
\hline 27 & $27 / 10 / 2012$ & BABÁ SURTA E MATA OS FILHINHOS DA PATROA A FACADAS \\
\hline 28 & 28/10/2012 & MAMÃE JOGOU AÇÚCAR EM MIM \\
\hline 29 & 29/10/2012 & TRÁFICO MANDA MATAR CÃO FARO FINO DA POLÍCIA \\
\hline 30 & $30 / 10 / 2012$ & 'COVARDIA' \\
\hline \multirow[t]{2}{*}{31} & $31 / 10 / 2012$ & 'O FRED É MANJA' \\
\hline & & NOVEMBRO \\
\hline 32 & $01 / 11 / 2012$ & SANDY FURACÃO DÁ PINTA EM NOVA YORK \\
\hline 33 & $02 / 11 / 2012$ & PELA-SACO DO MMA ESPANCA A EX EM POSTO DE GASOLINA \\
\hline 34 & 03/11/2012 & IMPERADOR NÃO TREINA NEM MORTO NO DIA DE FINADOS \\
\hline 35 & $04 / 11 / 2012$ & ZONA? SÓ COM O IMPERADOR \\
\hline 36 & $05 / 11 / 2012$ & TRÁFICO PROÍBE VENDA DE CRACK EM MADUREIRA \\
\hline 37 & $06 / 11 / 2012$ & COVARDÕES TACAM ÁCIDO NA CARA DA FILHA DE 15 ANOS \\
\hline 38 & 07/11/2012 & BONDE DO MAL EXPLODE FARMÁCIA E METE CAIXA ELETRÔNICO \\
\hline 39 & $08 / 11 / 2012$ & NEY LATORRACA TEM MELHORA E PODE VOLTAR A 'PÉ NA COVA' \\
\hline 40 & 09/11/2012 & MORTE APÓS ABORTO EM CLÍNICA PIRATA NA BAIXADA \\
\hline 41 & $10 / 11 / 2012$ & COMO PODE ESQUECER UM ANJINHO DESSES NO CARRO, MEU DEUS? \\
\hline
\end{tabular}




\begin{tabular}{|c|c|c|}
\hline 42 & $11 / 11 / 2012$ & FLUZÃO QUER KAKÁ, DENTUÇO, CONCA E MONTILLO PRA LIBERTA \\
\hline 43 & $12 / 11 / 2012$ & TETRACAMPEÃO \\
\hline 44 & $13 / 11 / 2012$ & $\begin{array}{l}\text { SAMBA DE LUTO: MORRE DELEGADO DA MANGUEIRA } \\
\text { EMOÇÃO NO ADEUS AO ATOR MARCOS PAULO } \\
\text { NIEMEYER JÁ ESTÁ MELHOR E FAZ ATÉ FISIOTERAPIA }\end{array}$ \\
\hline 45 & $14 / 11 / 2012$ & ÍDOLO SERTANEJO É BARRADO NO VELÓRIO DA EX \\
\hline 46 & $15 / 11 / 2012$ & PMS ACEITAVAM ATÉ GOIABADA COMO PROPINA \\
\hline 47 & $16 / 11 / 2012$ & CASAMENTO DE GIBA DO VÔLEI ACABA EM BARRACO \\
\hline 48 & $17 / 11 / 2012$ & ONDA DE TERROR EM SÃO PAULO: BANDIDOS MATAM ATÉ BEBÊ DE 1 ANO \\
\hline 49 & $18 / 11 / 2012$ & HOJE É DIA DE ORGULHO GAY \\
\hline 50 & $19 / 11 / 2012$ & BONDE DO MAL MANDA EM FESTA NA ILHA \\
\hline 51 & 20/11/2012 & NOIVO MORRE NA PRÓPRIA FESTA DE CASAMENTO \\
\hline 52 & $21 / 11 / 2012$ & 'SÓ VÃO ACHAR ELIZA SE PEIXE FALAR' \\
\hline 53 & $22 / 11 / 2012$ & BRUNO QUER LEVAR SEU JULGAMENTO PARA OS PÊNALTIS \\
\hline 54 & $23 / 11 / 2012$ & SAFADINHO FILMOU VUCO-VUCO DE ISIS VALVERDE \\
\hline 55 & $24 / 11 / 2012$ & EU, EU, EU, O MANO SE DEU MAL... \\
\hline 56 & $25 / 11 / 2012$ & ACUSAÇÃO APOSTA EM 20 ANOS DE CANA DURA PRA BRUNO \\
\hline 57 & $26 / 11 / 2012$ & BOPE DETONA GERAL EM NOVA IGUAÇU \\
\hline 58 & $27 / 11 / 2012$ & ESFAQUEADA ATÉ A MORTE NO HOSPITAL \\
\hline 59 & $28 / 11 / 2012$ & APESAR DA UPP, O BICHO PEGOU NO COMPLEXO \\
\hline 60 & $29 / 11 / 2012$ & FALSO NEYMAR DAVA GOLPES NA MULHERADA \\
\hline \multirow[t]{2}{*}{61} & $30 / 11 / 2012$ & GLOBO CHUTA DIDI E CASSETA \\
\hline & & DEZEMBRO \\
\hline
\end{tabular}




\begin{tabular}{|c|c|c|}
\hline 62 & $01 / 12 / 2012$ & MACONHEIROS VÃO FICAR NA SECA NA MARÉ \\
\hline 63 & $02 / 12 / 2012$ & EX-PM TEM PLANO PRA MATAR ‘DELEGA' \\
\hline 64 & 03/12/2012 & POR QUE NÃO FOI DE TÁXI, HUCK? \\
\hline 65 & $04 / 12 / 2012$ & MISS MORRE NA OPERAÇÃO DO SILICONE \\
\hline 66 & $05 / 12 / 2012$ & HÁ VAGAS NA PM \\
\hline 67 & $06 / 12 / 2012$ & MANÍACO DA CALCINHA É PRESO COM FIO DENTAL \\
\hline 68 & $07 / 12 / 2012$ & PASTOR DA MILÍCIA FAZIA O DIABO NA ZONA OESTE \\
\hline 69 & $08 / 12 / 2012$ & SARGENTO TARADO ERA TERROR DA ZONA NORTE \\
\hline 70 & 09/12/2012 & BANDIDAGEM MATA PM DE UPP E FECHA O COMÉRCIO NO ALEMÃO \\
\hline 71 & $10 / 12 / 2012$ & MULHER É EXECUTADA NA FRENTE DA FILHINHA DE 2 ANOS \\
\hline 72 & $11 / 12 / 2012$ & “ELE É UM MICHÊ, VAGABUNDO" \\
\hline 73 & $12 / 12 / 2012$ & $12 / 12 / 2012$ \\
\hline 74 & $13 / 12 / 2012$ & QUE SINISTRO, HEIN, RONALDO! \\
\hline 75 & $14 / 12 / 2012$ & LEANDRINHO DA MARÉ RODA NO AVIÃO E VOA PRA CADEIA \\
\hline 76 & $15 / 12 / 2012$ & MAROLA FAZ TRAFICANTE DO CV RODAR EM BÚZIOS \\
\hline 77 & $16 / 12 / 2012$ & FOGO NA SAARA \\
\hline 78 & $17 / 12 / 2012$ & TIMÃO É BI E QUER PEGAR O BAMBI \\
\hline 79 & $18 / 12 / 2012$ & TIROTEIO, SANGUE E MORTES NA DELEGACIA \\
\hline 80 & $19 / 12 / 2012$ & CAMPEÃO DO MMA FAZ SEXO SELVAGEM E QUEBRA O PINTO \\
\hline 81 & $20 / 12 / 2012$ & “MORRERAM FAZENDO O QUE TODOS GOSTAM DE FAZER" \\
\hline 82 & $21 / 12 / 2012$ & SE VOCÊ ESTÁ LENDO ESTA MANCHETE É PORQUE O MUNDO NÃO ACABOU!!!! \\
\hline 83 & $22 / 12 / 2012$ & BALEADA NO ÔNIBUS A CAMINHO DO TRABALHO \\
\hline 84 & 23/12/2012 & BIG BROTHER VASCÃO: TODA SEMANA UM CRAQUE DEIXA A CASA DE SÃO JANUÁRIO. ASSIM, O TIME VAI PRO PAREDÃO, DINAMITE! \\
\hline 85 & $24 / 12 / 2012$ & PAPAI NOEL DO MAL TOCA O TERROR \\
\hline
\end{tabular}




\begin{tabular}{|c|c|c|}
\hline 86 & $25 / 12 / 2012$ & SIMPATIAS PARA VOCÊ BOMBAR NO ANO NOVO \\
\hline 87 & $26 / 12 / 2012$ & NATAL DA COVARDIA \\
\hline 88 & $27 / 12 / 2012$ & MORRE A GUARDIÃ DO SEGREDO DE CHICO XAVIER \\
\hline 89 & $28 / 12 / 2012$ & A MANCHETE DERRETEU COM O CALOR \\
\hline 90 & $29 / 12 / 2012$ & JOVEM É MORTA POR BALA PERDIDA NO LINS \\
\hline 91 & $30 / 12 / 2012$ & PM É MORTO NA FRENTE DA FILHINHA \\
\hline \multirow[t]{2}{*}{92} & $31 / 12 / 2012$ & FORÇA , RAINHA! \#TAMOJUNTO “TROCARIA OS R\$2 MILHÕES DA FAZENDA PELA SAÚDE DO MEU PAI” \\
\hline & & JANEIRO \\
\hline 93 & $01 / 01 / 2013$ & ASTROS PREVEEM COMO SERÁ O ANO \\
\hline 94 & $02 / 01 / 2013$ & TURISTA É ASSASSINADO POR RECLAMAR DE R\$̧7 A MAIS NA CONTA DE RESTAURANTE \\
\hline 95 & $03 / 01 / 2013$ & TIROU ONDA NA RUA COM NOVINHA E A EX METEU A PEIXEIRA \\
\hline 96 & $04 / 01 / 2013$ & ZECA VIRA O HERÓI DA BAIXADA \\
\hline 97 & $05 / 01 / 2013$ & PITBOY DE TORCIDA ORGANIZADA VIRA MULHER \\
\hline 98 & 06/01/2013 & DEPOIS DE GATONET E BOLA GATO, AGORA É O GATOTRÁFICO \\
\hline 99 & $07 / 01 / 2013$ & HOMEM MATA A EX A FACADAS DENTRO DA UNIVERSAL \\
\hline 100 & $08 / 01 / 2013$ & CV DÁ DESCARGA EM CAGÃO E TOCA O TERROR NA CHATUBA \\
\hline 101 & $09 / 01 / 2013$ & FÃS SE CORTAM NA WEB PARA BIEBER LARGAR A MACONHA \\
\hline 102 & $10 / 01 / 2013$ & FEZ XIXI NA RUA E LEVOU CINCO BALAÇOS \\
\hline 103 & $11 / 01 / 2013$ & CROCODILO GIGANTE ERA SEGURANÇA DO TRÁFICO \\
\hline 104 & $12 / 01 / 2013$ & BANDIDO DE LUCAS SÓ QUERIA MOLEZA \\
\hline 105 & $13 / 01 / 2013$ & BAMBAM VIRA PEDRITA E VAZA DO BBB \\
\hline 106 & $14 / 01 / 2013$ & PAIS VÃO A PAGODE E BEBÊ MORRE EM INCÊNDIO \\
\hline 107 & $15 / 01 / 2013$ & CHAPÉU DE TOURO NO BIG BROTHER \\
\hline 108 & $16 / 01 / 2013$ & MOTORISTA MORRE APÓS BARRACO COM ATRIZ DA GLOBO \\
\hline
\end{tabular}




\begin{tabular}{|c|c|c|}
\hline 109 & $17 / 01 / 2013$ & FAMÍLIA QUE VENDE PÓ UNIDA PERMANECE UNIDA NA CADEIA \\
\hline 110 & $18 / 01 / 2013$ & É O BICHO, É O BICHO... VOU TE DEVORAR, CROCODILO EU SOU! \\
\hline 111 & $19 / 01 / 2013$ & GRÁVIDA DE OITO MESES APANHA DO MARIDO E FICA TETRAPLÉGICA \\
\hline 112 & $20 / 01 / 2013$ & “ACHEI QUE FOSSEM ME TACAR PEDRA E ME CUSPIR" \\
\hline 113 & $21 / 01 / 2013$ & COM O COFRINHO VIRADO PRA LUA \\
\hline 114 & $22 / 01 / 2013$ & PM QUEBRA TRIBUNAL DO CV NA ZONA NORTE \\
\hline 115 & $23 / 01 / 2013$ & ENFERMEIRO FAZ SEXO COM CADÁVER E ENTRA NUMA FRIA \\
\hline 116 & $24 / 01 / 2013$ & MASSACRE DA MOROSSERRA \\
\hline 117 & $25 / 01 / 2013$ & MANÍACO DA FACA ATACA NO CENTRO \\
\hline 118 & $26 / 01 / 2013$ & ESSES DOIS COVARDES MATARAM A PEQUENA GEOVANNA \\
\hline 119 & $27 / 01 / 2013$ & SAIBA COMO EMAGRECER ATÉ 5KG PRO CARNAVAL \\
\hline 120 & $28 / 01 / 2013$ & 233 MORTOS: QUEM VAI PAGAR POR ISSO? \\
\hline 121 & $29 / 01 / 2013$ & A MAIOR DOR DO MUNDO \\
\hline 122 & $30 / 01 / 2013$ & BONDE DO LINS DEBOCHA DA POLÍCIA \\
\hline \multirow[t]{2}{*}{123} & $31 / 01 / 2013$ & 171 TIRAVA ONDA DE DIRETOR DE NOVELA PRA ABUSAR DE NOVINHAS \\
\hline & & FEVEREIRO \\
\hline 124 & $01 / 02 / 2013$ & A PÓ-POZUDA: BUZANFA DE PATRICINHA ERA DE COCAÍNA \\
\hline 125 & $02 / 02 / 2013$ & SEM-NOÇÃO DÁ BOTE EM DELEGADO E É PRESO DE CUECA \\
\hline 126 & $03 / 02 / 2013$ & FIQUE COM O VISUAL DAS MUSAS DO ‘BBB’ GASTANDO POUQUINHO \\
\hline 127 & $04 / 02 / 2013$ & BANDIDÕES FOGEM COMO RATOS PELO ESGOTO DA CADEIA \\
\hline 128 & $05 / 02 / 2013$ & PASTOR MALAFAIA JOGA NO VENTILADOR: 'SE TIVER PASTOR GAY, ELE PERDE O CARGO' \\
\hline 129 & $06 / 02 / 2013$ & VOVÓ DA PÁ VIRADA RODA COM 3 MILHÕES NO CARRO \\
\hline 130 & $07 / 02 / 2013$ & PASTORA FAZ BOCA DE FUMO NA IGREJA E POSA COM ARMAS \\
\hline 131 & $08 / 02 / 2013$ & PM BUNDÃO ASSASSINA MODELO NA COVARDIA \\
\hline
\end{tabular}




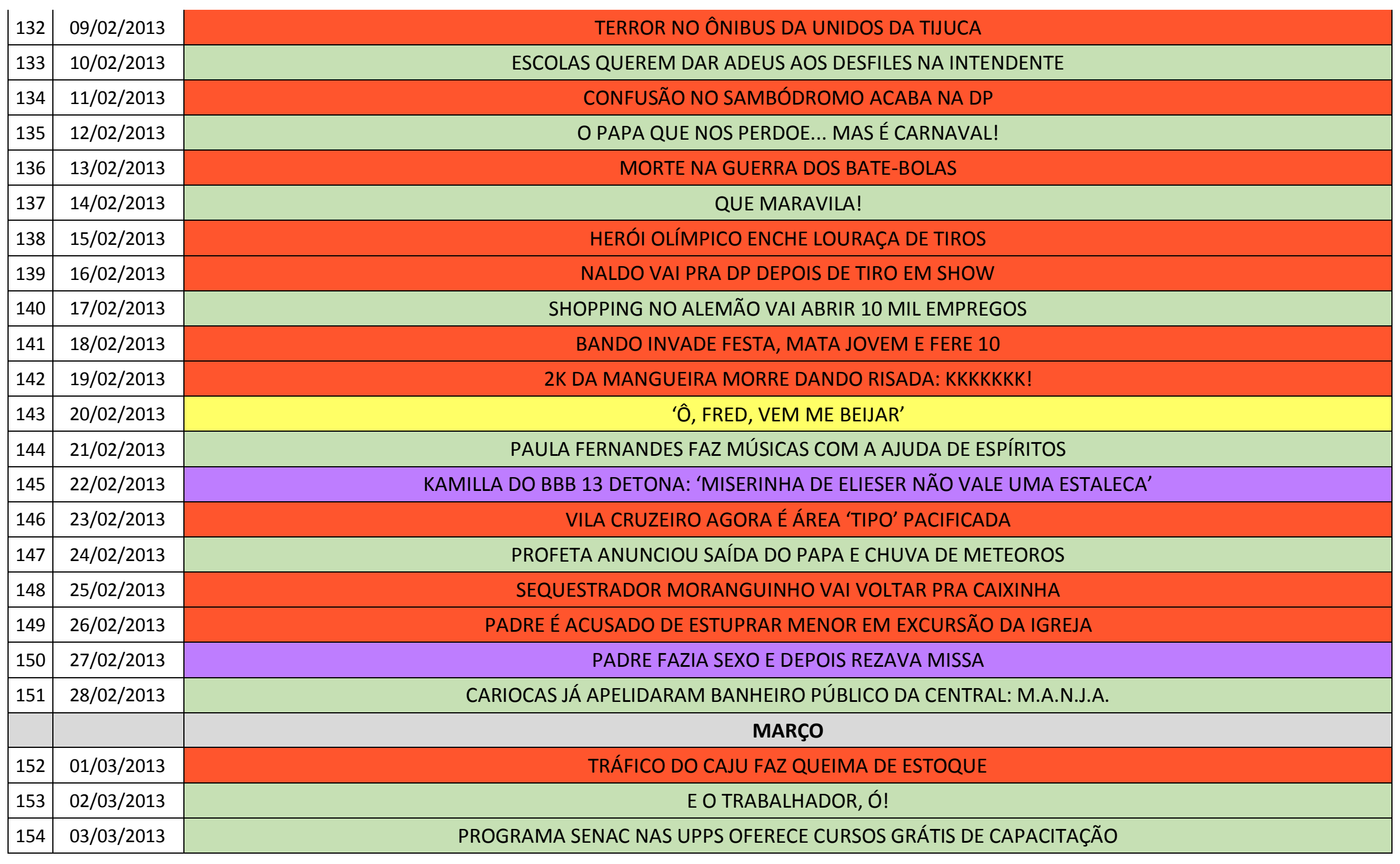




\begin{tabular}{|c|c|c|}
\hline 155 & $04 / 03 / 2013$ & ZICA DO ZICO PÕE FOGÃO NA FINAL \\
\hline 156 & $05 / 03 / 2013$ & MALDIÇÃO DO BEIJO AMARRA DOM FREDÓN \\
\hline 157 & $06 / 03 / 2013$ & CHÁVEZ MORRE SEM QUERER QUERENDO \\
\hline 158 & $07 / 03 / 2013$ & CHORÃO TROCA CHARLIE BROWN POR SEPULTURA \\
\hline 159 & $08 / 03 / 2013$ & MÃE DE ELIZA SAMÚDIO DIZ QUE FALA COM A FILHA MORTA \\
\hline 160 & $09 / 03 / 2013$ & MÃE DE ELIZA TEM MEDO DE BRUNO MATAR O PRÓPRIO FILHO \\
\hline 161 & $10 / 03 / 2013$ & MULHERADA DÁ DICAS PRA SABRINA CURTIR A ROCINHA \\
\hline 162 & $11 / 03 / 2013$ & É FOGÃO, LEK!!! \\
\hline 163 & $12 / 03 / 2013$ & DESSA VEZ NÃO VAMOS ZOAR O VICE. AFINAL, A AMIZADE ESTÁ EM 1ㅇ LUGAR! O VASCO VEM EM 2은 \\
\hline 164 & $13 / 03 / 2013$ & DJ CHORÃO DA MARÉ TEVE O CORAÇÃO ARRANCADO A MÃO \\
\hline 165 & $14 / 03 / 2013$ & OS ARGENTINOS JÁ TÊM O MESSI... E AGORA O PAPA? \\
\hline 166 & $15 / 03 / 2013$ & EX-NAMORADA DO NOVO PAPA ABRE O JOGO: 'ELE ME PEDIU EM CASAMENTO' \\
\hline 167 & $16 / 03 / 2013$ & JARARACA DA BAIXADA QUEIMA O BILAU DO EX \\
\hline 168 & $17 / 03 / 2013$ & BRUNO PERDEU 19KG DE TANTO FRANGO QUE ENGOLIU NA CADEIA \\
\hline 169 & $18 / 03 / 2013$ & HOMEM DÁ 4 TIROS DO EX-MARIDO DA FILHA DURANTE A MISSA \\
\hline 170 & $19 / 03 / 2013$ & HOMEM SEM PÊNIS JÁ LEVOU 100 MULHERES PRA CAMA \\
\hline 171 & $20 / 03 / 2013$ & POLÍCIA PESCA MULHER-PEIXE DA BAIXADA DENTRO DE RIO \\
\hline 172 & $21 / 03 / 2013$ & ADOREI! POLÍCIA ENJAULA DOREI DA ADA, CHEFÃO DO SÃO CARLOS \\
\hline 173 & $22 / 03 / 2013$ & $\begin{array}{l}\text { PRESO COM CARABINA, PISTOLA, REVÓLVER, MUNIÇÃO E MACONHA, SERTANEJO HUDSON FAZ DESABAFO PARA O FÃS 'ACHAVA } \\
\text { QUE TUDO ERA LEGAL' }\end{array}$ \\
\hline 174 & $23 / 03 / 2013$ & APITO É COISA DO PASSADO! ÍNDIO QUER MUSEU! GOVERNO NÃO DÁ E... O PAU COME! \\
\hline 175 & $24 / 03 / 2013$ & QUE CACHORRO NADA! CARTEIRO TEM MEDO É DE ASSALTANTE \\
\hline 176 & $25 / 03 / 2013$ & GALÃ DA GLOBO ESCAPA DA MORTE NA ZONA OESTE \\
\hline 177 & $26 / 03 / 2013$ & GUSTTAVO LIMA ESTÁ BOLADÃO E QUER ENCERRAR A CARREIRA \\
\hline
\end{tabular}




\begin{tabular}{|c|c|c|}
\hline 178 & $27 / 03 / 2013$ & $\begin{array}{l}\text { BESTA-FERA } \\
\text { MANICURE SEQUESTRA MENINO DE } 6 \text { ANOS NA ESCOLA E O SUFOCA COM UMA TOALHA. DEPOIS, RASGA AS ROUPAS DA CRIANÇA, } \\
\text { QUEIMA O TÊNIS, ESCONDE O CORPO NUMA MALA E AINDA VAI CONSOLAR A MÃE }\end{array}$ \\
\hline 179 & $28 / 03 / 2013$ & ELA CONTINUA A MESMA BESTA-FERA NA CADEIA, MAS OS SEUS CABELOS... \\
\hline 180 & 29/03/2013 & APÓS GRAVAR CANÇÃO GOSPEL, NEGUINHO SURPREENDE: 'DEUS É QUE SABE SE EU CONTINUO NO CARNAVAL' \\
\hline 181 & 30/03/2013 & BESTA-FERA TORTUROU MENININHO POR SETE MINUTOS \\
\hline \multirow[t]{2}{*}{182} & $31 / 03 / 2013$ & FAMOSAS USAM O CHOCOLATE PARA FICAR MAIS LINDAS \\
\hline & & ABRIL \\
\hline 183 & $01 / 04 / 2013$ & CRAQUE É FLAGRADO NA CAMA COM GATA DO COLEGA DE TIME \\
\hline 184 & 02/04/2013 & BESTA-FERA AMEAÇOU FAZER PICADINHO DE MENINO \\
\hline 185 & 03/04/2013 & HORROR NA AV. BRASIL \\
\hline 186 & 04/04/2013 & BABACÃO DO 328 CHUTOU A CARA DO MOTORISTA \\
\hline 187 & 05/04/2013 & THAMMY HOJE É ASSIM... MAS VAI FICAR ASSIM \\
\hline 188 & 06/04/2013 & 'ARMA DO MEU FILHO ERA UM CACHORRO-QUENTE’ \\
\hline 189 & 07/04/2013 & DANÇOU, GATINHO \\
\hline 190 & $08 / 04 / 2013$ & LADRÕES POSTAM JOIAS PARA VENDER NO 'FACE' \\
\hline 191 & 09/04/2013 & MONSTROS OFERECERAM AMERICANA ESTUPRADA NA VAN A CHEFÃO DO PÓ \\
\hline 192 & $10 / 04 / 2013$ & TIRO PRA TODO LADO NO SHOW DO BONDE DAS MARAVILHAS \\
\hline 193 & $11 / 04 / 2013$ & PADRE DIZ QUE DEUS DEU SEGUNDA CHANCE A TRÊS VÍTIMAS DA KISS \\
\hline 194 & $12 / 04 / 2013$ & QUADRILHA TENTA TOMAR DINHEIRO DE GUGU \\
\hline 195 & $13 / 04 / 2013$ & SUFOCO NA UPP DA ROCINHA \\
\hline 196 & $14 / 04 / 2013$ & FLA X VASCO? SÓ SE FOR NO ATERRO... \\
\hline 197 & $15 / 04 / 2013$ & GERENTE DE LOJA DE CARROS É PRESO POR CHACINA \\
\hline 198 & $16 / 04 / 2013$ & GERENTE CHAMOU IRMÃOS DO MAL PARA CASTIGAR GRUPO QUE COBRAVA DÍVIDA 'ELES IAM AMACIAR A CARNE’ \\
\hline
\end{tabular}




\begin{tabular}{|c|c|c|}
\hline 199 & $17 / 04 / 2013$ & BOMBEIRO PÕE A MANGUEIRA PRA JOGO NO QUARTEL \\
\hline 200 & $18 / 04 / 2013$ & CORNO REVELA OS DETALHES DO SEXO NO CARRO DOS BOMBEIROS \\
\hline 201 & $19 / 04 / 2013$ & O JEITO É IR A PÉ! \\
\hline 202 & $20 / 04 / 2013$ & PILOTO PÕE O TRABUCO PRA FORA NO BUSÃO \\
\hline 203 & $21 / 04 / 2013$ & VÁ DE BIKE E FIQUE COM TUDO EM CIMA! \\
\hline 204 & $22 / 04 / 2013$ & PINTO DE BORRACHA NA GARGANTA MATA ESPOSA \\
\hline 205 & $23 / 04 / 2013$ & ANA MARIA BRAGA VIRA ESTRELA DE VIDEOCASSETADA \\
\hline 206 & $24 / 04 / 2013$ & MONSTRO RODA POR ABUSAR DA PRÓPRIA FILHA \\
\hline 207 & $25 / 04 / 2013$ & SCOOBY-DOO, CADÊ VOCÊ, MEU FILHO? \\
\hline 208 & $26 / 04 / 2013$ & CRAQUE PEGA MULHER DE TRAFICANTE E ENTRA NA PORRADA \\
\hline 209 & $27 / 04 / 2013$ & LOURAÇA RUBRO-NEGRA PIROU O CABEÇÃO DE BERNARDO \\
\hline 210 & $28 / 04 / 2013$ & LOURAÇA MARCOU NA PELE O AMOR POR TRAFICANTE \\
\hline 211 & $29 / 04 / 2013$ & EMPRESÁRIO CHAMA BERNARDO DE '171' \\
\hline \multirow[t]{2}{*}{212} & $30 / 04 / 2013$ & PELADO E COM ARMA NA CABEÇA \\
\hline & & MAIO \\
\hline 213 & $01 / 05 / 2013$ & GATAS QUEBRAM O PAU POR CRISTIANO RONALDO \\
\hline 214 & $02 / 05 / 2013$ & BERNARDO ENTRA NA FACA \\
\hline 215 & 03/05/2013 & MENOR P. QUERIA QUE BERNARDO FIZESSE SEXO NO CATIVEIRO \\
\hline 216 & $04 / 05 / 2013$ & MANÍACO DA VAN ATROPELA TRÊS VEZES E MATA GAY EM SÃO GONÇALO \\
\hline 217 & 05/05/2013 & BOTAFOGUENSE VIRA TRICOLOR DEPOIS DE TRANSPLANTE \\
\hline 218 & $06 / 05 / 2013$ & É FOGO! \\
\hline 219 & $07 / 05 / 2013$ & AJUDE A POLÍCIA A PRENDER O MONSTRO DO BUSÃO \\
\hline 220 & $08 / 05 / 2013$ & ATACANTE DO FLUZÃO USOU PÓ. E NÃO ERA PÓ DE ARROZ \\
\hline 221 & $09 / 05 / 2013$ & PASTOR MARCOS FAZIA O DIABO EM NOME DE DEUS \\
\hline
\end{tabular}




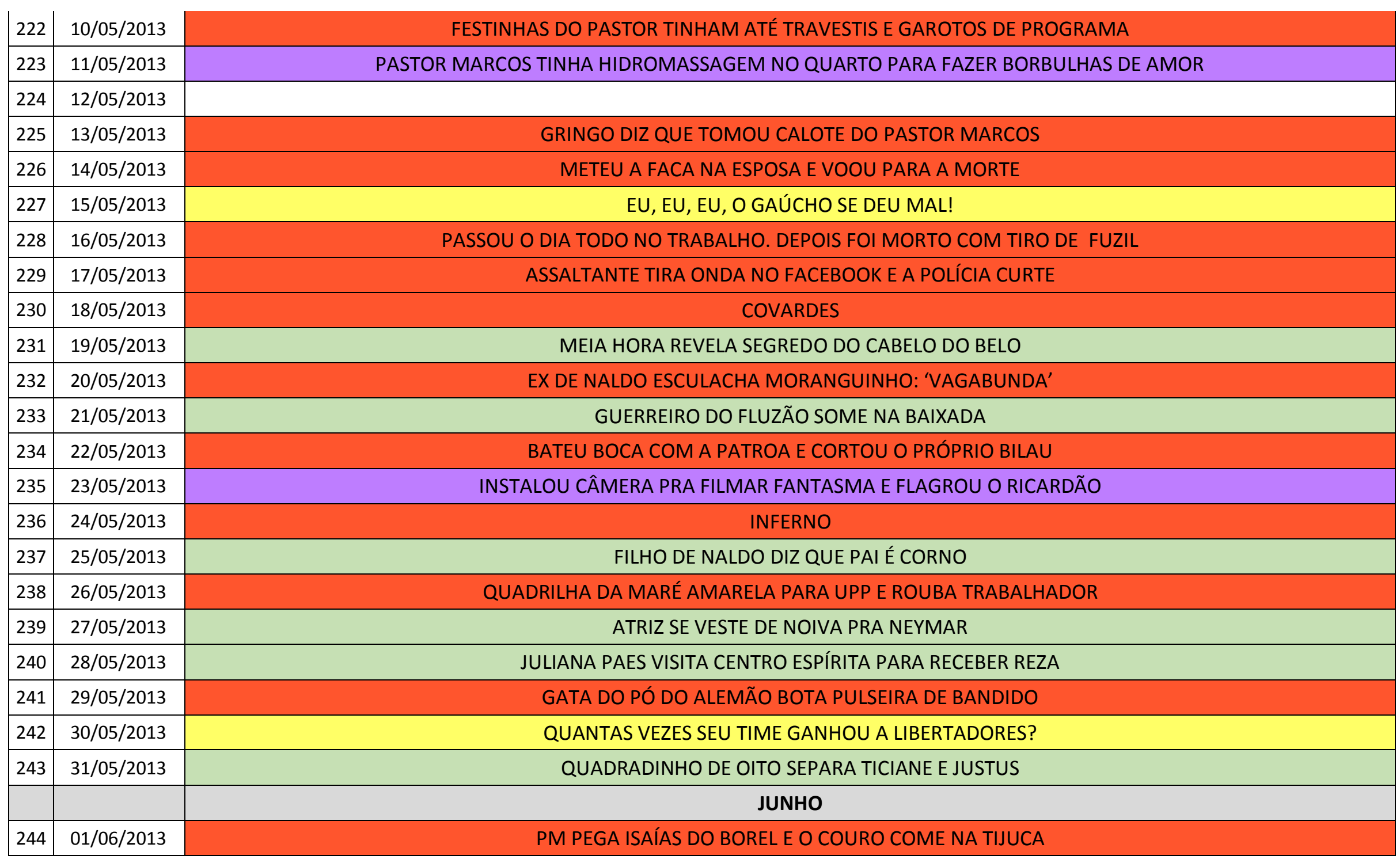




\begin{tabular}{|c|c|c|}
\hline 245 & $02 / 06 / 2013$ & MEIA HORA PROCURA A GATA NO ESPELHO \\
\hline 246 & $03 / 06 / 2013$ & SÓ GANHA NO VIDEOGAME \\
\hline 247 & $04 / 06 / 2013$ & CEBOLA DO CV VAI CHORAR NA CADEIA \\
\hline 248 & $05 / 06 / 2013$ & HOMEM DE 66 ANOS VAI AO MÉDICO E DESCOBRE QUE É MULHER \\
\hline 249 & 06/06/2013 & MÃE ENJAULA FILHO QUE NEM BICHO E SAI COM A NAMORADA \\
\hline 250 & $07 / 06 / 2013$ & NOVINHA DO MUAY-THAI FINALIZA A MÃE COM MATA-LEÃO \\
\hline 251 & $08 / 06 / 2013$ & NOVINHA DIABÓLICA GRAVOU NA PELE PACTO QUE FEZ COM NAMORADO \\
\hline 252 & $09 / 06 / 2013$ & ALELUIA \\
\hline 253 & $10 / 06 / 2013$ & EXPLODE A GUERRA DAS VANS NA ZONA OESTE \\
\hline 254 & $11 / 06 / 2013$ & ATOR FAZ DESABAFO: 'VI A MORTE DE PERTO' \\
\hline 255 & $12 / 06 / 2013$ & FUNKEIRO TIRA FOTO COM 'FUZIL' E VAI PARAR NO FACEBOOK \\
\hline 256 & $13 / 06 / 2013$ & VOVÔS QUEREM VIAGRA NA CESTA BÁSICA \\
\hline 257 & $14 / 06 / 2013$ & LARANJINHA ESPREME A NAMORADA ATÉ VIRAR SUCO \\
\hline 258 & $15 / 06 / 2013$ & TARADÃO MOSTRA O BIMBINHO PRA MISS BRASIL E SE DÁ MAL \\
\hline 259 & $16 / 06 / 2013$ & MICHAEL JACKSON ASSOMBRA OS PRÓPRIOS FILHOS \\
\hline 260 & $17 / 06 / 2013$ & PAI LEVA BALA NA CABEÇA AO PROTEGER BEBEZINHO \\
\hline 261 & $18 / 06 / 2013$ & TIRO! PORRADA! BOMBA! \\
\hline 262 & $19 / 06 / 2013$ & QUEM FAZ QUEBRA-QUEBRA NA PASSEATA É... \\
\hline 263 & $20 / 06 / 2013$ & TARIFA R\$2,75 \\
\hline 264 & $21 / 06 / 2013$ & CHEGA! \\
\hline 265 & $22 / 06 / 2013$ & TÉCNICO DO FOGÃO É ACUSADO DE BATER NA SOGRA \\
\hline 266 & $23 / 06 / 2013$ & VÂNDALOS DA CONCESSIONÁRIA DÃO MARCHA A RÉ PARA A CADEIA \\
\hline 267 & $24 / 06 / 2013$ & ANITTA: 'LEVEI SPRAY DE PIMENTA NA CARA' \\
\hline 268 & $25 / 06 / 2013$ & FESTINHA DA SELEÇÃO SÓ TINHA NOVINHA ‘PADRÃO FIFA’ \\
\hline
\end{tabular}




\begin{tabular}{|c|c|c|}
\hline 269 & $26 / 06 / 2013$ & INFERNO NA MARÉ: 9 MORTOS \\
\hline 270 & $27 / 06 / 2013$ & MENINO DE 15 ANOS MATA O IRMÃO COM GOLPE DE GUARDA-CHUVA \\
\hline 271 & $28 / 06 / 2013$ & FANTASMA DO VICE APAVORA A GALERA \\
\hline 272 & $29 / 06 / 2013$ & VOVÔ TARADO ATACAVA A MULHERADA NA COVARDIA \\
\hline \multirow[t]{2}{*}{273} & $30 / 06 / 2013$ & TE AMO, ESPANHOLA! \\
\hline & & JULHO \\
\hline 274 & $01 / 07 / 2013$ & CHUPA, TIC-TAC! \\
\hline 275 & $02 / 07 / 2013$ & CAVALIERI MOSTRA O TROFÉU E ESPOSA TIRA ONDA: 'MORRAM DE INVEJA' \\
\hline 276 & $03 / 07 / 2013$ & CARRAPATO DA BAIXADA VAI SE COÇAR NO XADREZ \\
\hline 277 & $04 / 07 / 2013$ & PM BOTA ÁGUA NO CHOPE DO TRÁFICO \\
\hline 278 & 05/07/2013 & JUIZ DE FUTEBOL MATA JOGADOR E É ESQUARTEJADO PELA TORCIDA \\
\hline 279 & 06/07/2013 & FINALIZOU \\
\hline 280 & $07 / 07 / 2013$ & CONHEÇA AS FINALISTAS DO CONCURSO 'GATA NO ESPELHO’ \\
\hline 281 & $08 / 07 / 2013$ & FUNKEIRO É MORTO A TIRO EM CIMA DO PALCO \\
\hline 282 & $09 / 07 / 2013$ & GALERÃO DO ROLA ENTRA RASGANDO E DEIXA GERAL SEM BRT \\
\hline 283 & $10 / 07 / 2013$ & EX-CHEFÃO DO PÓ NA ROCINHA VAI PRA TERRA DOS PÉS JUNTOS \\
\hline 284 & $11 / 07 / 2013$ & ARGENTINO BOTA A MIXARIA PRA FORA E VAI PRA DP PELADÃO \\
\hline 285 & $12 / 07 / 2013$ & ESSE TÁ FEDIDO! \\
\hline 286 & $13 / 07 / 2013$ & HOMEM É ATINGIDO POR 'VACA PERDIDA' E VAI PRO BREJO \\
\hline 287 & $14 / 07 / 2013$ & O 'MEIA' REVELA OS SEGREDOS QUE AS CELEBRIDADES ESCONDEM EM SEUS E-MAILS \\
\hline 288 & $15 / 07 / 2013$ & HOMEM LEVA FACADA NO CORAÇÃO NA FESTA DE 15 ANOS DA FILHA \\
\hline 289 & $16 / 07 / 2013$ & POLÍCIA USA VÍDEO DE FUNK PROIBIDÃO PRA IDENTIFICAR TRAFICANTES DA ROCINHA \\
\hline 290 & $17 / 07 / 2013$ & PREVISÃO SINISTRA DA VIDENTE ANITTA VIRA REALIDADE \\
\hline 291 & $18 / 07 / 2013$ & CHEFÃO COMANDA O TRÁFICO DE DENTRO DO COMPLEXO DE BANGU \\
\hline
\end{tabular}




\begin{tabular}{|c|c|c|}
\hline 292 & $19 / 07 / 2013$ & THIAGUINHO É INTERNADO E CANCELA TODOS OS SHOWS ATÉ AGOSTO \\
\hline 293 & $20 / 07 / 2013$ & LADRÃO VÊ IMAGEM SE MEXER E DESMAIA EM LOJA DE UMBANDA \\
\hline 294 & $21 / 07 / 2013$ & SHOW DA PODEROSA DO 'MEIA' FAZ GERAL BABAR! \\
\hline 295 & $22 / 07 / 2013$ & DUPLA VAI PRO BREJO COM DROGA E CELULAR NA PERERECA \\
\hline 296 & $23 / 07 / 2013$ & O PAPA VAI PRA GALERA! \\
\hline 297 & $24 / 07 / 2013$ & 'NÃO FIQUEI ASSUSTADO. FOI CARINHO' \\
\hline 298 & $25 / 07 / 2013$ & TRAFICANTE MATA EX-CAVEIRA E FOGE DO HOSPITAL PELA JANELA DO BANHEIRO \\
\hline 299 & $26 / 07 / 2013$ & ‘PEREGRINOS NÃO VÃO PODER ARMAR A BARRACA' AVISA PAES \\
\hline 300 & $27 / 07 / 2013$ & MENINO QUE FEZ O PAPA CHORAR QUER SER PADRE \\
\hline 301 & $28 / 07 / 2013$ & ACABOU A MARRA DO CHEFÃO DA MILÍCIA \\
\hline 302 & $29 / 07 / 2013$ & ATÉ BREVE, PAPA \\
\hline 303 & $30 / 07 / 2013$ & PAPA DOA GRANA PARA MELHORIAS NA FAVELA DE VARGINHA \\
\hline \multirow[t]{2}{*}{304} & $31 / 07 / 2013$ & ATÉ QUANDO O POVO VAI PAGAR PELOS ERROS DOS PODEROSOS? \\
\hline & & AGOSTO \\
\hline 305 & $01 / 08 / 2013$ & PRESIDIÁRIOS CORTAM BILAU, MÃOS E ORELHA DE ESTUPRADOR DE CRIANCINHA \\
\hline 306 & 02/08/2013 & MUSA PADRÃO FIFA TÁ NA CADEIA \\
\hline 307 & 03/08/2013 & BOLA NAS COSTAS NO FOGÃO! \\
\hline 308 & 04/08/2013 & PRO RECALQUE PASSAR LONGE \\
\hline 309 & 05/08/2013 & HOMEM É QUEIMADO APÓS ATROPELAR E MATAR CRIANCINHA \\
\hline 310 & 06/08/2013 & BOMBEIRO CHEIO DE FOGO PEGA A NORA E ENTRA NO CACETE \\
\hline 311 & 07/08/2013 & FOI MEL NA CHUPETA: \\
\hline 312 & 08/08/2013 & POLIÇADA ENJAULA A JARARACA QUE ROUBOU BEBEZINHA \\
\hline 313 & 09/08/2013 & VAGABUNDAGEM COMO MOSCA NA GUERRA DO SAPO \\
\hline 314 & $10 / 08 / 2013$ & PEQUENA ISA NÃO FOI ESGANADA POR MÃO HUMANAS \\
\hline
\end{tabular}




\begin{tabular}{|c|c|c|}
\hline 315 & $11 / 08 / 2013$ & FIZERAM M... NA CÂMARA! E DESSA VEZ NÃO FORAM SÓ OS POLÍTICOS... \\
\hline 316 & $12 / 08 / 2013$ & UH, PAPAI CHEGOU! \\
\hline 317 & $13 / 08 / 2013$ & BROCADOR É MAU, PEGA UM, PEGA GERAL! \\
\hline 318 & $14 / 08 / 2013$ & MATOU O ENTEADO DE TRÊS ANOS COM SOCO NA BARRIGA \\
\hline 319 & $15 / 08 / 2013$ & SARGENTO MELÃO VAI FICAR FININHO COM DIETA DA CADEIA \\
\hline 320 & $16 / 08 / 2013$ & PERIGUETE NOVINHA SEDUZIA OS MANÉS PRA ROUBAR DE ESPINGARDA \\
\hline 321 & $17 / 08 / 2013$ & BANDIDO FAZ GRACINHA NO FACEBOOK E AGORA CURTE A CADEIA \\
\hline 322 & $18 / 08 / 2013$ & PERIGUETE DO CRISTIANO RONALDO É RUIM DE CAMA \\
\hline 323 & $19 / 08 / 2013$ & BONDE DO MAL PÕE PÓ DO DEMO EM SANTA E RODA \\
\hline 324 & $20 / 08 / 2013$ & JOVEM É ESTUPRADA APÓS BAILE FUNK EM COMUNIDADE COM UPP \\
\hline 325 & $21 / 08 / 2013$ & CANTOR GOSPEL É ACUSADO DE ESTUPRAR A FILHA \\
\hline 326 & $22 / 08 / 2013$ & LADRÃO DO DEMÔNIO ROUBAVA O DÍZIMO DA UNIVERSAL \\
\hline 327 & $23 / 08 / 2013$ & PERDEU \\
\hline 328 & $24 / 08 / 2013$ & PEGOU GATA DE BANDIDO E LEVOU TIRO NO PINTO \\
\hline 329 & $25 / 08 / 2013$ & VAMPIRO DA VIDA REAL MATA O PAI E BEBE SANGUE \\
\hline 330 & $26 / 08 / 2013$ & MC CAROL PROMETE FICAR NA MEDIDA CERTA \\
\hline 331 & $27 / 08 / 2013$ & PAI DE SANTO PREVIU A PRISÃO DE OFICIAL DA PM \\
\hline 332 & $28 / 08 / 2013$ & DECO PENDURA O CHINELINHO ‘UÉ, MAS ELE AINDA JOGAVA?’ \\
\hline 333 & $29 / 08 / 2013$ & BANHO DE SANGUE \\
\hline 334 & $30 / 08 / 2013$ & PADRE FAZ FILHO EM FIEL \\
\hline \multirow[t]{2}{*}{335} & $31 / 08 / 2013$ & É MUITA SACANAGEM! \\
\hline & & SETEMBRO \\
\hline 336 & $01 / 09 / 2013$ & MANÍACO DA RASPADINHA VIOLENTOU 12 HOMENS E NÃO SE ARREPENDE \\
\hline 337 & $02 / 09 / 2013$ & ZÉ RUELAS ENTERRAM HOMEM VIVO NA PRAIA DE IPANEMA E VÃO EM CANA \\
\hline
\end{tabular}




\begin{tabular}{|c|c|c|}
\hline 338 & 03/09/2013 & JOGADOR DO FLU QUE SUMIU FOI PICOTADO E JOGADO EM RIO \\
\hline 339 & $04 / 09 / 2013$ & HOMEM SE APAIXONA POR CABRA E VAI CASAR \\
\hline 340 & $05 / 09 / 2013$ & AGORA VAI! \\
\hline 341 & $06 / 09 / 2013$ & LOURAÇA DA CAPA PRETA ATERRORIZA MOTORISTAS DE ÔNIBUS \\
\hline 342 & 07/09/2013 & TÁ AMARRADO: POLIÇADA GRAMPEIA R\$ 1 MILHÃO NO TERREIRO \\
\hline 343 & $08 / 09 / 2013$ & SUJEITO FAZ 'BUNDALELÊ' NA CARA DO CHOQUE E VAI PRA TRANCA \\
\hline 344 & 09/09/2013 & MÃE LUTA PRA LIMPAR A MEMÓRIA DE MILITAR EXECUTADO \\
\hline 345 & $10 / 09 / 2013$ & PLAYBOY DO PÓ LEVOU COÇA DA ESPOSA \\
\hline 346 & $11 / 09 / 2013$ & CARA, CARAMBA! O CARA VAZOU DO CHICLETE! \\
\hline 347 & $12 / 09 / 2013$ & 11 DE SETEMBRO EM MARICÁ \\
\hline 348 & $13 / 09 / 2013$ & URUBU COME PEIXE E PREPARA VOO PRO G-4 \\
\hline 349 & $14 / 09 / 2013$ & É MEDIDA CERTA OU NAMORO NA TV? \\
\hline 350 & $15 / 09 / 2013$ & BEYONCÉ DÁ AULA DE REBOLAR O LELEK, LEK, LEK \\
\hline 351 & $16 / 09 / 2013$ & POVÃO EM FÚRIA DESCABELA PALHAÇO ASSALTANTE \\
\hline 352 & $17 / 09 / 2013$ & ASTRO DA TV LARGA A MULHER E PEGA GATO SARADÃO \\
\hline 353 & $18 / 09 / 2013$ & AMARROU O IRMÃO E ESTUPROU A CUNHADA \\
\hline 354 & $19 / 09 / 2013$ & CRACUDO TÁ ROUBANDO ATÉ MORTO NA BRASIL \\
\hline 355 & $20 / 09 / 2013$ & PM AGARRA DEDO PODRE DO BONDE DO MÃO \\
\hline 356 & $21 / 09 / 2013$ & MENGÃO: PAGUE PARA SAIR E REZE PARA NÃO ENTRAR \\
\hline 357 & $22 / 09 / 2013$ & MEIA ENSINA VOCÊ A TER... \\
\hline 358 & $23 / 09 / 2013$ & NEM COM REZA FORTE \\
\hline 359 & $24 / 09 / 2013$ & CRISE EM RIO \\
\hline 360 & $25 / 09 / 2013$ & \\
\hline 361 & $26 / 09 / 2013$ & PERIGUETE PEDE PROVA DE AMOR E NAMORADO ENTERRA O RIVAL VIVO \\
\hline
\end{tabular}




\begin{tabular}{|c|c|c|}
362 & $27 / 09 / 2013$ & TIQUINHO DA COVANCA LEVA TECÃO NA IDEIA \\
\hline 363 & $28 / 09 / 2013$ & TARADÃO ATRAÍA MENINAS COM DOCE DE COSME E DAMIÃO \\
\hline 364 & $29 / 09 / 2013$ & TIRAVA ONDA COM OURO E LEVOU CHUMBO \\
\hline 365 & $30 / 09 / 2013$ & ISSO É MENGÃO! \\
\hline
\end{tabular}

